\title{
INFLUÊNCIA DO GENÓTIPO, SEXO E PESO DE ABATE NA COMPOSIÇÃO DA CARCAÇA E NAS CARACTERÍSTICAS DE QUALIDADE DA CARNE SUÍNA
}

\author{
Camila Nogueira Angerami
}

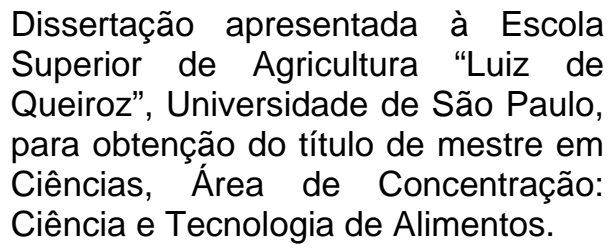

$P \mid R A C I C A B A$

Estado de São Paulo - Brasil

Julho - 2004 


\title{
INFLUÊNCIA DO GENÓTIPO, SEXO E PESO DE ABATE NA COMPOSIÇÃO DA CARCAÇA E NAS CARACTERÍSTICAS DE QUALIDADE DA CARNE SUÍNA
}

\author{
Camila Nogueira Angeramı \\ Médico Veterinário
}

Orientadora Profa. Dra. MARÍLIA OETTERER

Dissertação apresentada à Escola
Superior de Agricultura "Luiz de
Queiroz", Universidade de São Paulo,
para obtenção do título de mestre em
Ciências, Área de Concentração:
Ciência e Tecnologia de Alimentos.

PIR A C ICABA

Estado de São Paulo - Brasil

Julho - 2004 


\section{Dados Internacionais de Catalogação na Publicação (CIP) DIVISÃO DE BIBLIOTECA E DOCUMENTAÇÃO - ESALQ/USP}

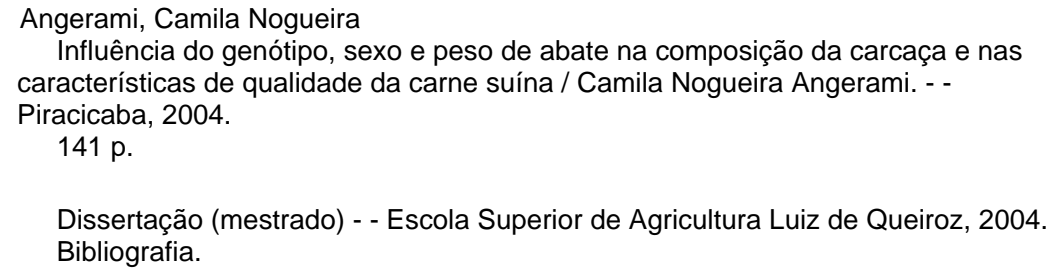

1. Abate 2. Carcaça 3. Carne suína 4. Genótipo 5. Qualidade dos alimentos I. Título

CDD 664.92 


\section{Dedico}

\section{Ao meu filho, milha vida, Pedro}

\section{Ofereço}

Aos meus pais, a quem deve tudo que hoje sou, Tuga e Shalimar 


\section{AGRADECIMENTOS}

Em primeiro lugar, aos meus pais, Tuga e Shalimar, pelo apoio e incentivo nas minhas escolhas e pelos esforços ilimitados para minha formação pessoal e profissional.

Ao meu marido, Sebastián, pelo apoio, incentivo e companheirismo.

Ao Dr. Expedito Tadeu Facco Silveira, pelo apoio, orientação, ensinamentos e incentivo durante toda a realização deste trabalho.

À Profa. Dra. Marília Oetterer pela oportunidade para a realização deste trabalho.

À Dra. Carmen Josefina Contreras Castillo e à Dra. Ana Lúcia da Silva Correa Lemos pelas sugestões dadas no exame de qualificação.

Ao Instituto de Tecnologia de Alimentos (ITAL), em especial ao Centro de Tecnologia de Carnes, (CTC), pela oportunidade para a realização deste trabalho. 
À Escola Superior de Agricultura "Luiz de Quieroz" (ESALQ/USP), em especial ao Departamento de Agroindústria, Alimentos e $\mathcal{N}$ utrição pela oportunidade para a realização deste trabalho.

À Coordenadoria de Aperfeiçoamento do Pessoal de Ensino Superior (CAPES), pela bolsa de estudos concedida.

Ao Frigorífico PIF PAF, em Patrocínio, Minas Gerais, e a todos os funcionários que colaboraram para a realização deste trabalho.

Aे Empresa Seghers Genetics do Brasil e a todos os funcionários que colaboraram para a realização deste trabalho.

Ao Prof. Dr. Ângelo Catâneo, pela fundamental ajuda na realização das análises estatísticas deste trabalho.

Ás amigas e colegas de mestrado, Vanessa Pires da Rosa, Márcia Harada e Cristiane Fenimam, por todos os momentos, alegres e difíceis, compartilhados e pela grande amizade construída e sedimentada durante a realização deste trabalho.

À amiga Nelisa Lamas, pela força nos momentos difíceis e pela amizade, sempre.

Aos meus familiares, irmão, avós, tios e primos, pelo incentivo. 


\section{SUMÁRIO}

Página

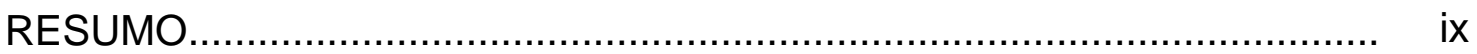

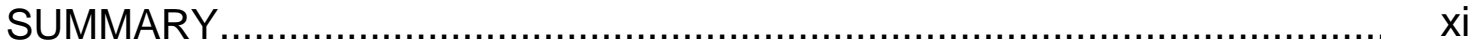

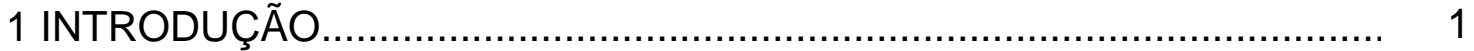

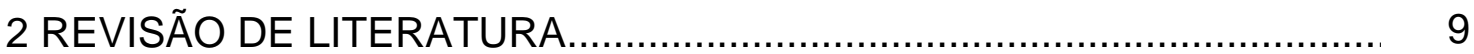

2.1 Qualidade da carne suína............................................................. 9

2.2 Fatores que afetam a qualidade da carne suína................................. 9

2.2.1 Genótipo.................................................................................... 10

2.2.1.1 Gene Halotano............................................................... 11

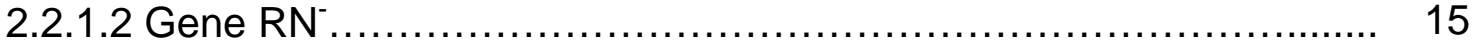

2.2.1.3 Efeitos poligênicos...................................................... 17

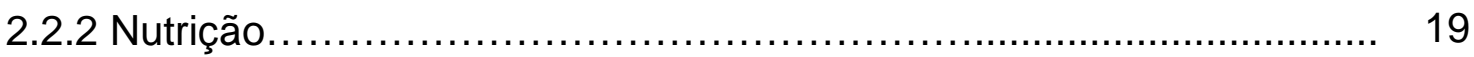

2.2.2.1 Manipulação dos níveis de glicogênio muscular.............................. 19

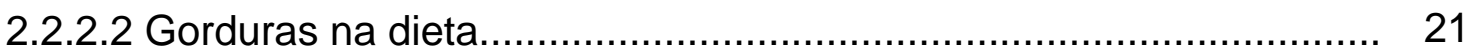

2.2.2.3 Suplementação com vitamina E e outros antioxidantes na

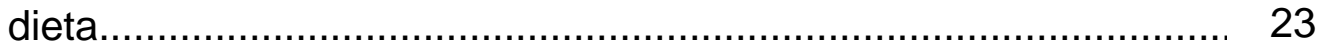

2.2.2.4 Redução do estresse através da alimentação................................. 24

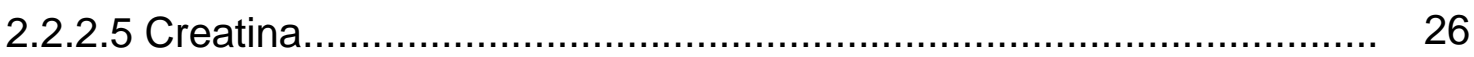

2.2.3 Sistemas de produção............................................................... 27 


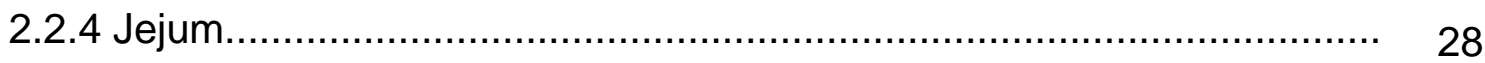

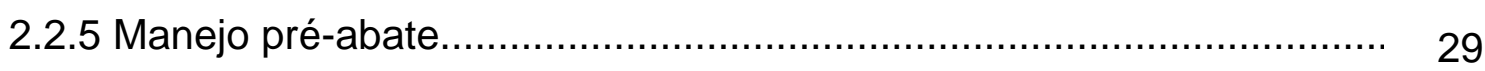

2.2.6 Métodos de insensibilização...................................................... 34

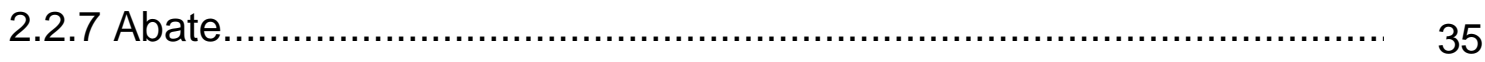

2.2.7.1 Linha de processo e resfriamento............................................ 35

2.2.7.2 Estimulação elétrica.............................................................. 36

2.2.7.3 Suspensão pélvica................................................................. 37

2.3 Fatores que favorecem o desenvolvimento das condições PSE e

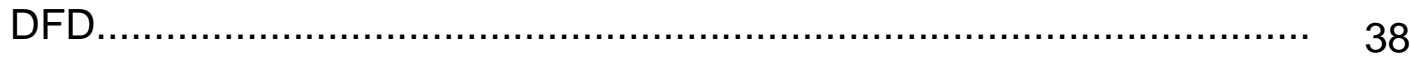

2.4 Redução do pH da carne suína e suas relações com a qualidade......... 42

2.4.1 Como o pH afeta a cor da carne ................................................... 44

2.4.2 Como o pH afeta a maciez da carne............................................. 45

2.4.3 Como o pH afeta a capacidade de retenção de água (CRA).............. 45

2.5 Composição da carcaça e quantidade de carne suína............................ 46

2.6 Fatores que afetam a composição da carcaça e a quantidade da carne

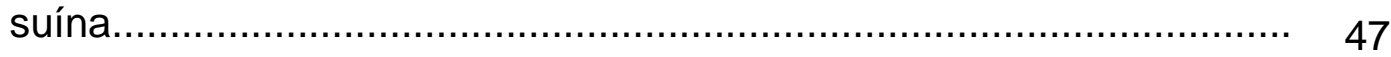

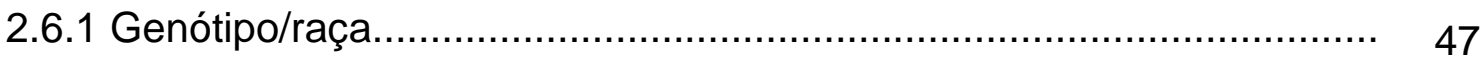

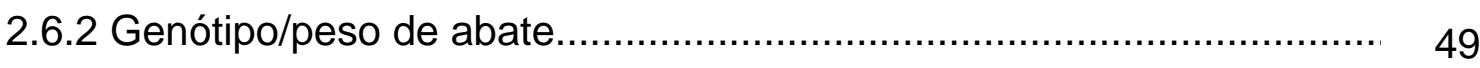

2.6.3 Nutrição/manejo/genótipo.......................................................... 50

2.6.4 Sistemas de produção/manejo/genótipo/sexo................................. 53

2.6.5 Peso de abate/sexo............................................................... 55

2.6.6 Peso de abate/sexo/raça.......................................................... 59

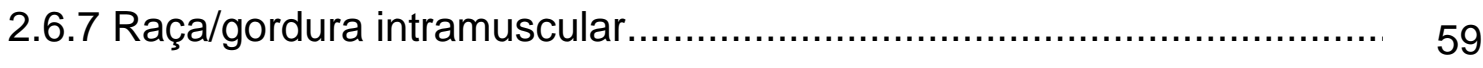

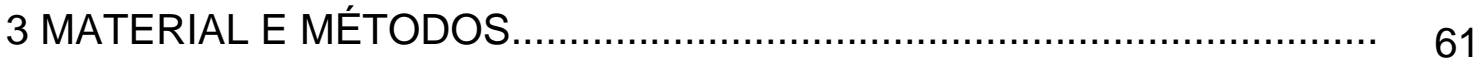

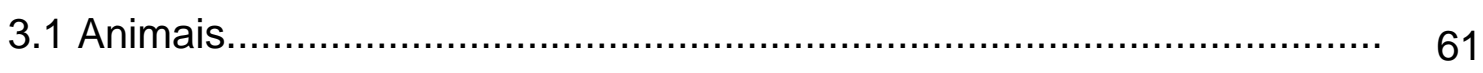

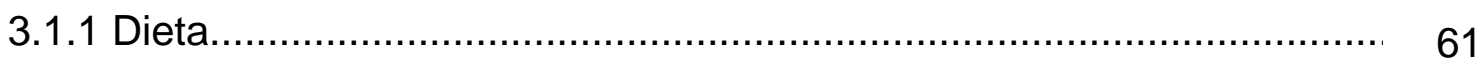

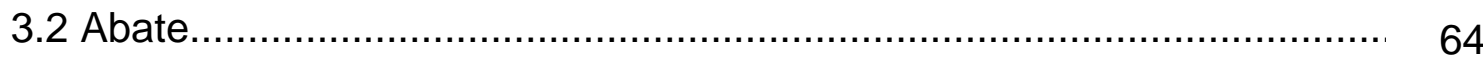

3.3 Medidas de composição da carcaça..................................................... 69

3.3.2 Área de olho de lombo (AOL), comprimento de olho de lombo (COL), profundidade de toucinho (PT) ...................................................... 70 
3.3.3 Tipificação eletrônica................................................................ 70

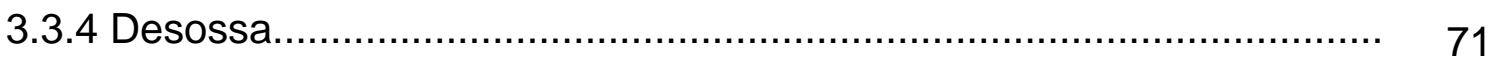

3.3.5 Determinação da porcentagem de carne magra (\%CM) .................... 71

3.4 Avaliações da qualidade de carne .................................................. 71

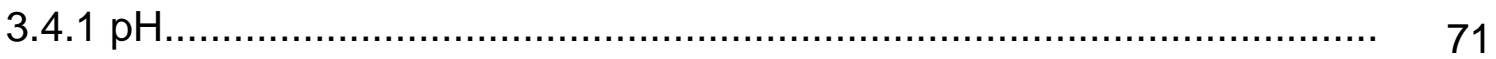

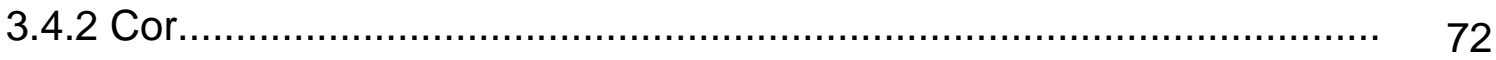

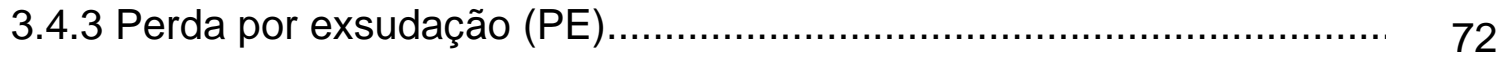

3.4.4 Capacidade de retenção de água (CRA)...................................... 72

3.5 Análise estatística...................................................................... 73

4 RESULTADOS E DISCUSSÃO.......................................................... 74

4.1 Influência do genótipo, sexo e peso de abate na composição da

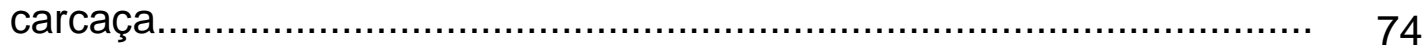

4.2 Influência do genótipo, sexo e peso de abate nas características de qualidade de carne .................................................................... 87

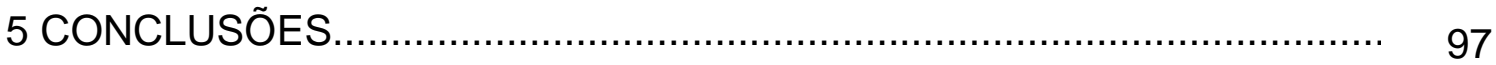

REFERÊNCIAS BIBLIOGRÁFICAS............................................... 100 


\title{
INFLUÊNCIA DO GENÓTIPO, SEXO E PESO DE ABATE NA COMPOSIÇÃO DA CARCAÇA E NAS CARACTERÍSTICAS DE QUALIDADE DA CARNE SUÍNA
}

\author{
Autora: CAMILA NOGUEIRA ANGERAMI \\ Orientadora: Profa. Dra. MARÍLIA OETTERER
}

\section{RESUMO}

O experimento consistiu de dezesseis tratamentos distribuídos num esquema fatorial 4x2x2, sendo 4 genótipos (Excel (E) - Nn, Linha 21 (L21) nn, Maximus (M) - NN e Optimus (O) - NN), 2 sexos (machos castrados e fêmeas) e 2 pesos (leves - 95 a $100 \mathrm{Kg}$ e pesados - 115 a 120Kg) e seis repetições. Foram realizadas medidas de composição da carcaça: Peso da Carcaça Resfriada (PCR), Área de Olho de Lombo (AOL), Comprimento de Olho de Lombo (COL), Profundidade de Toucinho (PT), Porcentagem de Carne Magra (\%CM) e medidas de Espessuras de Músculo (EM) e Gordura (EG) e avaliações de qualidade de carne: $\mathrm{pH}$, cor $\left(L^{*} \mathrm{a}^{*} \mathrm{~b}^{*}\right)$, Perda por Exsudação (PE) e Capacidade de Retenção de Água (CRA). Os resultados estatísticos da composição da carcaça para o genótipo nn indicaram valor de AOL significativamente superior em relação aos genótipos $\mathrm{Nn}, \mathrm{NN}_{\mathrm{M}}$ e $\mathrm{NN}_{\mathrm{O}}$ e valor de PT significativamente menor que $\mathrm{NN}_{\mathrm{M}}$ e $\mathrm{NN}$, porém, não diferindo de $\mathrm{Nn}$. Quanto à EM, ocorreu uma tendência do $\mathrm{NN}_{\mathrm{M}}$ apresentar os maiores valores, seguido pelo $\mathrm{Nn}, \mathrm{nn}$ e $\mathrm{NN}_{\mathrm{O}}$. Em relação à $E G, N_{0}$ mostrou os maiores valores, não diferindo significativamente de $\mathrm{NN}_{M}$ e $n n$, enquanto o 
genótipo $\mathrm{Nn}$ apresentou o menor valor para esta característica. A \%CM dos genótipos nn e $\mathrm{Nn}$ foi significativamente maior que $\mathrm{NN}_{\mathrm{M}}$ e $\mathrm{NN}_{\mathrm{O}}$, confirmando a expressão do gene recessivo ( $n$ ) em depositar mais carne na carcaça que o dominante $(\mathrm{N})$. Os resultados estatísticos de qualidade de carne mostraram que o genótipo nn apresentou o menor valor de $\mathrm{pH}_{24}$ no músculo Semimembranosus, combinado com os maiores valores de luminosidade $\left(L^{*}\right)$ e PE em comparação com $\mathrm{Nn}, \mathrm{NN}_{\mathrm{M}}$ e $\mathrm{NN}_{\mathrm{O}}$. Não houve diferença significativa entre os genótipos $\mathrm{NN}$ and $\mathrm{Nn}$ na $\mathrm{PE}$. Em relação à $\mathrm{CRA}, \mathrm{NN}_{\mathrm{M}}$ obteve valor significativamente menor que $\mathrm{Nn}, \mathrm{nn}$ e $\mathrm{NN}_{\mathrm{O}}$. Os resultados obtidos permitem concluir que o gene halotano em homozigose (L21) contribuiu para a obtenção de uma carcaça mais musculosa, porém, com qualidade de carne inferior, apresentando maior incidência de carne PSE. Em relação ao sexo, os machos resultaram carcaças mais pesadas, mais gordas e carne com menor luminosidade. Finalmente, com exceção da \%CM, os valores de composição da carcaça aumentaram com o peso de abate, não sendo constatadas mudanças nas características de qualidade avaliadas. 


\title{
INFLUENCE OF GENOTYPE, SEX AND SLAUGHTER WEIGHT IN THE CARCASS COMPOSITION AND QUALITY CHARACTERISTICS OF PORK MEAT
}

\author{
Author: CAMILA NOGUEIRA ANGERAMI \\ Adviser: Profa. Dra. MARÍLIA OETTERER
}

\section{SUMMARY}

This experiment consisted of sixteen treatments in a $4 \times 2 \times 2$ factorial arrangement, 4 genotypes (Excel - Nn, Line 21 - nn, Maximus - NN and Optimus - NN), 2 sexes (barrows and gilts) and 2 weights (light $-95-100 \mathrm{Kg}$ and heavy $-115-120 \mathrm{Kg}$ ) and 6 repetition. The exams were submitted to the following carcass composition measurements: Cold Carcass Weight (CCW), Loin Eye Area (LEA), Loin Eye Length (LEL), Fat Depth (FD), Lean Meat Percentage (LM\%) and Fat (FT) and Muscle (MT) Thickness. Meat quality measurements were also realized: $\mathrm{pH}$, Color $\left(\mathrm{L}^{*} \mathrm{a}^{*} \mathrm{~b}^{\star}\right)$, Drip Loss $(\mathrm{DL})$ and Water Holding Capacity (WHC). The results of this study showed that genotype nn had shown significantly higher values of LEA than another genotypes and significantly lower values of $\mathrm{FD}$ than $\mathrm{NN}_{\mathrm{M}}$ and $\mathrm{N} \mathrm{N}_{\mathrm{O}}$, and it didn't differ from genotype $\mathrm{Nn}$. There was a tendency by genotype $\mathrm{NN}_{\mathrm{M}}$ to show higher values of MT followed by $\mathrm{Nn}, \mathrm{nn}$ and $\mathrm{NN}_{\mathrm{O}}$. Genotype $\mathrm{NN}_{\mathrm{O}}$ showed higher values to $\mathrm{FT}$ and did not differed significantly from $\mathrm{NN}_{\mathrm{M}}$ and $\mathrm{nn}$, while genotype $\mathrm{Nn}$ showed lower values to this characteristic. Genotypes $\mathrm{nn}$ and $\mathrm{Nn}$ showed significantly higher values of $\mathrm{LM} \%$ than $\mathrm{NN}_{\mathrm{M}}$ and $\mathrm{NN}_{\mathrm{O}}$. With reference to meat quality, 
genotype $\mathrm{nn}$ has shown lower value of $\mathrm{pH}_{24}$ measured in the muscle Semimenbranosus and higher values of $L^{*}$ and $D L$ than genotypes $N n, N N_{M}$ and $\mathrm{NN}_{\mathrm{O}}$. Genotype $\mathrm{NN}_{\mathrm{M}}$ had significantly higher values of $\mathrm{WHC}$ than $\mathrm{nn}, \mathrm{Nn}$ and $\mathrm{NN}_{\mathrm{O}}$. There was no significant difference between $\mathrm{NN}$ and $\mathrm{Nn}$ when considered $\mathrm{DL}$. The results above indicate that halothane gene in homozygous $(\mathrm{nn})$ helped to obtain more muscular carcasses. On the other hand, this genotype showed worst meat quality. As a consequence of that, genotype nn has shown higher incidence of pale, soft and exudative meat. With reference to sex, barrows had significantly higher values to CCW, FD, FT, $L^{*}$ and $b^{*}$, resulting paler meat and heavier and fatter carcass than gilts. Except for LM\%, as carcass weight increased there were increases in all the characteristics. The data from this study suggest that there were no meat quality differences between the two slaughter weights. 


\section{INTRODUÇÃO}

O consumo mundial de carne suína, colocada em primeiro lugar na preferência da população, é altamente expressivo, chegando a 15,06 Kg per capita/ano (Roppa, L., 2004). Este fato, associado a maior participação do Brasil no mercado internacional (de 64 mil toneladas de carne suína exportada em 1997 para 500 mil toneladas em 2003, Roppa, 2004) bem como ao aumento das exigências do consumidor, tem feito com que a carne suína mereça maior atenção por parte dos diversos segmentos da cadeia produtiva.

A maioria dos estudos desenvolvidos nas décadas de 1960 a 1980 relata que a carne suína apresenta maiores teores de colesterol se comparada a outros tipos de carne (Bohac \& Rhee, 1988; Reitmeier \& Prusa, 1987; Tu et al., 1967). Isto pode ser explicado, pois, nos primeiros 50 anos do século 20 , foi muito comum o uso das gorduras animais na alimentação humana. Naquele período, o porco atendeu às exigências do mercado consumidor e a banha passou a ser um produto tão importante quanto suas carnes nobres, o lombo e o pernil. Naquela época, o porco apresentava 40 a $45 \%$ de carne magra na carcaça e espessuras de toucinho de 5 a 6 centímetros. Com o aparecimento das margarinas vegetais, as banhas deixaram de ser usadas, forçando o criador de suínos a buscar um novo modelo de animal, que melhor atendesse a um consumidor que estava mudando seu perfil de consumo, devido ao seu novo modo de vida (Buege et al., 1997).

O novo modelo que o suinocultor passou a desenvolver foi o de um animal com menos gordura, mais carne e maior eficiência na conversão dos alimentos. Para atingir este objetivo, houve uma mudança drástica nos métodos 
de manejo e instalações e ocorreu uma evolução marcante nas áreas de genética e nutrição. Como resultado deste investimento, um animal mais competitivo surgiu no mercado. "O porco fez dieta e virou suíno" e passou a apresentar de 58 a $62 \%$ de carne magra na sua carcaça e apenas 1 a $1,5 \mathrm{~cm}$ de espessura de toucinho.

O desafio para este novo modelo de suíno é combinar, adequadamente, o binômio qualidade e quantidade de carne, objetivando garantir a viabilidade econômica da indústria cárnea.

Neste sentido, a suinocultura brasileira vem, nos últimos anos, aumentando seus investimentos no que diz respeito à genética animal, com a adoção do cruzamento entre raças, visando, com isto, um maior rendimento de carne na carcaça, com menor quantidade de gordura.

Geralmente, a porcentagem de gordura na carcaça é dependente do sexo, do genótipo e do peso de abate (Niewilhof et al., 1991). Campbell e Taverner (1988) relataram que a seleção para diminuir a espessura de gordura e melhorar o aproveitamento da dieta utilizada resultou em suínos com maior potencial para ganho de peso. Foi visto também que, dentro de um genótipo, diferenças no sexo resultam em alterações na performance de crescimento, acréscimo de proteína e deposição de carne magra na carcaça (Campbell e Taverner, 1988; Stahly et al., 1991).

Porém, deve-se levar em consideração o fato de que os genótipos suínos que proporcionam uma carcaça com maior quantidade de carne magra, tendem a produzir carcaças pobres em qualidade (Eggert et al., 1996), resultando em dificuldades nos mecanismos de processamento e numa menor aceitabilidade pelo consumidor (Eggert et al., 1997). Frank et al. (1997) relataram que, em geral, genótipos selecionados para uma eficiente deposição de carne na carcaça, através do aumento de carne magra e diminuição de gordura, apresentaram uma menor quantidade de alimento ingerida, menores níveis de gordura intramuscular e qualidade de carne menos desejável.

Considerando a cadeia produtiva da carne suína e seus efeitos na 
qualidade final da carne, o genótipo representa aproximadamente $50 \%$ da incidência da carne PSE (pálida, flácida, exsudativa), enquanto que o manejo pré-abate, 15 a $20 \%$ e o resfriamento, 25 a 35\%. Esses fatores afetam a velocidade de glicólise post mortem (declínio do $\mathrm{pH}$ ) e a redução da temperatura no músculo, que são considerados os dois parâmetros determinantes do grau de desnaturação da proteína. Offer \& Knight (1989) constataram que a ocorrência de uma glicólise post mortem muito rápida em músculos com temperatura superior a $34^{\circ} \mathrm{C}$ resultou em uma severa desnaturação da proteína e, conseqüentemente, em uma redução da capacidade de retenção de água (CRA).

Carnes com características de qualidade inaceitáveis resultam em perdas econômicas que podem inviabilizar as atividades de um frigorífico, pois: -reduzem o rendimento de abate e do produto processado; -levam à desclassificação de carcaças e limitam a utilização da carne para a industrialização de produtos cárneos;

-afetam a qualidade da carne e de produtos industrializados, ocasionando:

- comprometimento da cor e fatiabilidade dos produtos cárneos cozidos;

- pobre formação de cor em produtos cárneos curados;

- descoloração e formação de odores estranhos;

- redução na vida de prateleira do produto.

Kauffman et al. (1992) reportaram que a indústria frigorífica Norte Americana trabalha com grandes proporções de carne PSE (pálida, flácida e exsudativa). Cannon et al. (1996), estimam que estas anomalias representam perdas de aproximadamente 100 milhões de dólares anuais para a economia Norte Americana. Na Austrália, estas perdas chegam a aproximadamente U\$20 milhões anualmente.

Wirth (1986) resume as características da carne PSE (Figura 1) e DFD (dura, firme e ressecada na superfície) (Figura 2) e apresenta as limitações de sua utilização na elaboração de produtos cárneos. Segundo o autor, a carne PSE pode ser destinada até certo limite para a elaboração de alguns produtos 
fermentados (presunto cru e salame seco) e certos tipos de emulsionados (salsicha tipo Frankfurt), mas é inadequada para a elaboração de presunto cozido e outros produtos curados cozidos. A carne DFD pode ser utilizada para o processamento de produtos emulsionados (salsicha tipo Frankfurt) e produtos curados cozidos (formulados com $60 \%$ de carne normal para que seja obtida uma coloração desejável), não sendo recomendada para o processamento de produtos fermentados e secos (Barton Gade, 1985). 


\begin{tabular}{|c|c|}
\hline Propriedades & Características \\
\hline $\begin{array}{c}\text { Capacidade de } \\
\text { Retenção de água }\end{array}$ & $\begin{array}{l}\text { Maior perda por gotejamento (1à } 4 \% \text { mais alta) em } \\
\text { carne fresca; Maior depósito de gelatina e gordura ( } 3 \text { à } \\
5 \% \text { mais alto) em produtos emulsionados; Menor } \\
\text { rendimento(3 à } 6 \% \text { mais baixo) para presunto cozido; } \\
\text { Produtos assados e grelhados (perdas de peso } \\
\text { variando entre } 2 \text { à } 6 \% \text { ) }\end{array}$ \\
\hline $\begin{array}{c}\text { Absorção dos } \\
\text { ingredientes de cura }\end{array}$ & $\begin{array}{l}\text { Aumento na absorção do sal e alteração na cor curada } \\
\text { (esbranquiçada) }\end{array}$ \\
\hline $\begin{array}{l}\text { Características } \\
\text { Sensoriais }\end{array}$ & Sabor ácido acentuado \\
\hline Vida-de-prateleira & $\begin{array}{l}\text { A superfície úmida da carne fresca contribui ás vezes } \\
\text { para reduzir a vida-de-prateleira. }\end{array}$ \\
\hline \multicolumn{2}{|c|}{ Pode ser usada para o processamento de: } \\
\hline Salame & $\begin{array}{l}\text { Desde que formulado com } 30 \% \text { de uma mistura de } \\
\text { carne bovina e suína normais, para evitar riscos } \\
\text { durante o processo }\end{array}$ \\
\hline Presunto cru & $\begin{array}{l}\text { Em pernis grandes, a diferença da cor dos músculos é } \\
\text { acentuada. O produto, às vezes, se apresenta muito } \\
\text { seco e deficiente em aroma }\end{array}$ \\
\hline Salsicha Frankfurt & $\begin{array}{l}\text { Recomenda-se formular com } 20 \% \text { de carne bovina e } \\
\text { suína normais, para favorecer o rendimento do } \\
\text { processo }\end{array}$ \\
\hline \multicolumn{2}{|c|}{ Inadequada para o processamento de: } \\
\hline Presunto cozido & $\begin{array}{l}\text { Drástica redução do rendimento do processo (devido } \\
\text { às elevadas perdas durante o cozimento e/ou maiores } \\
\text { depósitos de gelatina) }\end{array}$ \\
\hline
\end{tabular}

Figura 1 - Propriedades da carne PSE $\left(\mathrm{pH}_{1 \mathrm{~h}}<5,8\right)$ 


\begin{tabular}{|c|c|}
\hline Propriedades & Características \\
\hline $\begin{array}{l}\text { Capacidade de } \\
\text { Retenção de } \\
\text { água }\end{array}$ & $\begin{array}{l}\text { Menor liberação de água durante o tratamento térmico } \\
\text { Vantajoso para salsicha Frankfurt, presunto cozido, } \\
\text { assados e grelhados. Produto suculento e mais macio }\end{array}$ \\
\hline $\begin{array}{l}\text { Absorção dos } \\
\text { ingredientes de } \\
\text { cura }\end{array}$ & $\begin{array}{l}\text { Redução da absorção do sal em porções musculares } \\
\text { maiores e pobre desenvolvimento e retenção da cor } \\
\text { curada }\end{array}$ \\
\hline $\begin{array}{l}\text { Características } \\
\text { Sensoriais }\end{array}$ & Ausência do sabor ácido \\
\hline Vida-de-prateleira & $\begin{array}{l}\text { Redução da vida-de-prateleira tanto para a carne fresca } \\
\text { como para produtos industrializados }\end{array}$ \\
\hline \multicolumn{2}{|c|}{ Pode ser usada para o processamento de: } \\
\hline Salsicha Frankfurt & $\begin{array}{l}\text { Recomenda-se formular com } 40 \% \text { de carne bovina e } \\
\text { suína normais, para estender a vida-de-prateleira }\end{array}$ \\
\hline Presunto cozido & $\begin{array}{l}\text { Recomenda-se formular com } 60 \% \text { de carne suína } \\
\text { normal, para melhorar a vida de prateleira e a retenção } \\
\text { de cor }\end{array}$ \\
\hline \multicolumn{2}{|c|}{ Inadequada para o processamento de: } \\
\hline Presunto crú & $\begin{array}{l}\text { Vida-de-prateleira menor e riscos de processamento, } \\
\text { particularmente quando o pernil com osso é utilizado }\end{array}$ \\
\hline Salame & $\begin{array}{l}\text { Recomenda-se formular com carne normal e adicionar } \\
\text { maiores quantidades de açúcar, para evitar riscos nos } \\
\text { estágios iniciais do processo de fermentação }\end{array}$ \\
\hline
\end{tabular}

Figura 2 - Propriedades da carne DFD $\left(\mathrm{pH}_{24 \mathrm{~h}}>6,2\right)$ 
Townsend et al. (1980, citado por Silveira, 1997) investigaram a utilização de carne suína PSE, na elaboração de salame. Os resultados indicaram que o tempo de secagem foi reduzido em até $60 \%$ quando comparado com o produto formulado com carne suína normal. Entretanto, reportaram a possibilidade da existência de problemas devido ao desenvolvimento de rancidez e perda de textura.

Kauffman et al.., (1978, citado por Silveira, 1997) verificaram que pernis com características PSE, DFD e normal apresentaram as seguintes perdas de peso quando submetidos às condições comerciais de distribuição de carne refrigerada: $1,51 \%, 0,23 \%$ e $0,45 \%$, respectivamente. Durante o processamento (cura, defumação e resfriamento), as perdas de peso foram maiores: 5,71\%, 1,645 e 3,95\%, para os pernis PSE, DFD e normal, respectivamente.

Diante dessas observações, é de grande valor lembrar que, além da quantidade, a qualidade é o fator de maior importância para a indústria da carne suína, principalmente devido ao fato de que em média $75 \%$ dessa carne é destinada à industrialização. Neste sentido, existe uma tendência da indústria de suínos no Brasil em aumentar o peso de abate dos animais, de $100 \mathrm{Kg}$ para $130 \mathrm{Kg}$. As vantagens da produção de suínos mais pesados são reconhecidas pelas indústrias de abate e de processamento.

Tradicionalmente, a principal limitação para o aumento dos pesos de abate são os altos níveis de gordura observados nas carcaças dos animais mais pesados e a deterioração observada na eficiência alimentar desses animais (Cisneros et al., 1996). Entretanto, o potencial genético dos suínos comerciais tem mudado muito nos últimos anos, particularmente com relação às taxas de deposição de carne magra nas carcaças (Cisneros et al., 1996). Atualmente, as agroindústrias já estão adotando a idéia de aumentar o peso de abate. Genótipos selecionados para uma maior eficiência no ganho de carne magra têm sido abatidos com pesos maiores, de 115 a $120 \mathrm{Kg}$ de peso vivo, apresentando menos efeito no mérito das carcaças e/ou na conversão alimentar. Além disso, uma grande atenção tem sido dada à qualidade de carne 
(Morgan et al., 1994) e qualquer consideração de aumento no peso de abate requer a avaliação do impacto deste aumento na qualidade da carne, bem como nas características de composição da carcaça.

Fundamentado nas considerações realizadas anteriormente, o binômio qualidade e quantidade de carne suína tem merecido a atenção da indústria e da comunidade científica e é objeto de estudo da presente investigação, que explora o efeito do genótipo, sexo e peso de abate na composição da carcaça e nas características de qualidade da carne suína. 


\section{REVISÃO DE LITERATURA}

\subsection{Qualidade da carne suína}

Qualidade da carne suína abrange propriedades inerentes decisivas que garantem o sucesso da industrialização de produtos cárneos e do mercado de carne fresca. Os principais atributos de interesse são as características sensoriais (aparência, cor, sabor, textura e suculência), a capacidade de retenção de água (CRA), o conteúdo e a composição de gordura, a estabilidade oxidativa e a uniformidade (Rosenvold et al., 2003).

Qualidade tecnológica consiste numa propriedade complexa e multivariável da carne, a qual é influenciada por múltiplos fatores integrantes. Estes incluem raça, genótipo, alimentação, manejo pré-abate, insensibilização, método de abate, resfriamento e condições de estocagem. Composição e conteúdo de gordura, uniformidade e estabilidade oxidativa são os atributos de qualidade afetados, principalmente, pelo genótipo e pela estratégia alimentar, enquanto que a CRA e a cor são afetadas por quase todos os fatores acima mencionados (Rosenvold et al., 2003).

\subsection{Fatores que afetam a qualidade da carne suína}

As anomalias PSE (pálida, flácida e exsudativa) e DFD (escura, firme e ressecada na superfície) são sempre causadas pelo estresse que 
geralmente, mas nem sempre, estão associadas a uma condição genética que determina o PSS (síndrome da sensibilidade ao estresse) (Silveira, 1997). Entretanto, além dos fatores genéticos, as condições ambientais ante e post mortem podem influenciar a qualidade da carne.

Laack \& Smulders (1991) verificaram que a perda de água por exsudação não depende apenas de fatores intrínsecos, tais como a genética do animal e o tipo de músculo, mas também do manejo pré-abate e da velocidade de resfriamento da carcaça. Esses fatores afetam a velocidade de glicólise post mortem e a redução de temperatura do músculo, que são considerados os dois parâmetros determinantes do grau de desnaturação protéica. Offer \& Knight (1989) constataram que a ocorrência de uma glicólise post mortem muito rápida em músculos com temperatura superior a $34^{\circ} \mathrm{C}$ resultou numa desnaturação severa da proteína e, conseqüentemente, numa redução da CRA. Em casos extremos, essas condições resultariam em uma carne PSE (Silveira, 1997).

Considerando os estudos realizados sobre manejo pré - abate, Barton Gade (1993) relatou que somente aqueles fatores afetando a reserva de energia muscular no momento da sangria (alimentação, transporte, condições climáticas, tempo de espera na pocilga, sistema de coleta utilizado para conduzir os animais da pocilga até o local da insensibilização, métodos de insensibilização) têm importantes relações com a qualidade da carne.

\subsubsection{Genótipo}

A influência da genética na qualidade da carne suína compreende diferenças entre raças bem como diferenças entre animais da mesma raça. Essas diferenças podem ser causadas por um grande número de genes com efeitos menores, conhecidos como efeitos poligênicos. Entretanto, os atributos de qualidade da carne suína podem estar associados com efeitos monogênicos maiores. Alguns genes são conhecidos como principais (Sellier \& Monin, 1994). 
Dentre eles, destacam-se o gene Halotano e o gene $\mathrm{RN}^{-}$, que exercem uma influência direta na qualidade tecnológica da carne suína (Garnier et al., 2003).

\subsubsection{Gene Halotano}

O gene Halotano, referido como o gene da Síndrome do Estresse Porcino, causa hipertermia malignante, que pode ser desencadeada por estresse ou exposição ao gás anestésico halotano (Sellier, 1998). Os efeitos desse gene têm sido, desde a década de 60, associados ao desenvolvimento de carne pálida, flácida e exsudativa (PSE) (Briskey, 1964). O desenvolvimento de carne PSE é causado por uma extensiva desnaturação das proteínas, devido à combinação de um baixo $\mathrm{pH}$ e, simultaneamente, altas temperaturas post mortem (Briskey, 1964; Offer \& Knight, 1988).

Na década de 60, foi reportado que certas raças (Pietrán, Poland China, Landrace belga) continham uma grande proporção de animais propensos a apresentar carne PSE, enquanto que outras raças eram praticamente livres desta anomalia (Sellier, 1998). Algumas diferentes raças de suínos estão classificadas na Figura 3, de acordo com sua susceptibilidade ao estresse (Gregory, 1998). Christian (1972) foi o primeiro a lançar a hipótese de que existia uma variação monogênica na susceptibilidade ao estresse. Pouco tempo depois, Eikelenboom e Minkema (1974) mostraram que suínos homozigóticos para o gene Halotano (nn) reagiam ao gás halotano, sendo então o gene nomeado de acordo. Alguns países, como a Dinamarca, Suíça e Suécia eliminaram a presença do gene Halotano de suas linhas selecionadas, muitos anos atrás. Entretanto, somente no final da década de 90 algumas das maiores empresas internacionais de genética decidiram remover o gene Halotano de suas linhas de seleção (Rosenvold et al., 2003). 


\begin{tabular}{|c|c|c|}
\hline $\begin{array}{c}\text { Sensível } \\
\text { ao estresse }\end{array}$ & $\begin{array}{c}\text { Sensibilidade média } \\
\text { ao estresse }\end{array}$ & $\begin{array}{l}\text { Resistente } \\
\text { ao estresse } \\
\end{array}$ \\
\hline $\begin{array}{c}\text { Pietrain } \\
\text { Landrace Belga } \\
\text { China Polonês } \\
\text { Landrace Alemão }\end{array}$ & $\begin{array}{l}\text { Landrace Holandês } \\
\text { Landrace Francês } \\
\text { Landrace Sueco } \\
\text { Landrace Suíço } \\
\text { Landrace Dinamarquês } \\
\text { Landrace Norueguês } \\
\text { Landrace Australiano } \\
\text { Landrace Irlandês } \\
\text { Yorkshire Holandês } \\
\text { Hampshire Americano }\end{array}$ & $\begin{array}{l}\text { Large White Irlandês } \\
\text { Large White Australiano } \\
\text { Large White Françês } \\
\text { Large White Inglês } \\
\text { Yorkshire Americano } \\
\text { Duroc }\end{array}$ \\
\hline
\end{tabular}

Figura 3 - Susceptibilidade ao estresse e predisposição à produção de carne PSE em diferentes raças suínas

Um grande número de estudos tem analisado o efeito do gene Halotano na performance e na qualidade da carne. Em geral, suínos homozigóticos e heterozigóticos para o gene Halotano possuem maiores rendimentos de carcaça e porcentagem de carne magra (Aalhus et al., 1991; García - Marcías et al., 1996; Herfort Pedersen, et al., 2001; Larzul et al., 1997; McPhee et al., 1994; McPhee e Trout, 1995; Rundgren et al., 1990). O efeito positivo do gene Halotano em relação à performance é, entretanto, contrabalançado por seu efeito negativo nas características de cor e de capacidade de retenção de água. Como o nome gene da Síndrome do estresse suíno indica, animais que carregam este gene são altamente susceptíveis ao estresse. Mesmo durante um cuidadoso manejo, o estresse que acompanha o tratamento pré-abate é suficiente para desencadear uma maior taxa de glicólise post mortem em suínos homozigóticos $(\mathrm{nn})$ ou heterozigóticos $(\mathrm{Nn})$, sendo este mais severo nos animais nn (Lundström et al., 1989; Mittchel e Heffron, 1982). Isto desencadeia um aumento na velocidade das reações post mortem e, conseqüentemente, uma redução nos valores de $\mathrm{pH}\left(\mathrm{pH}_{45 \min }<6,0\right)$ combinado com temperaturas elevadas, os quais induzem o desenvolvimento de carne PSE, caracterizada por 
uma alta desnaturação protéica $(\mathrm{pH}$ final $<5,5)$ (Bend - all e Wismer Pedersen, 1962).

Weeb et al., (1982) relataram que o gene Halotano na forma heterozigótica $(\mathrm{Nn})$ mostrou efeitos benéficos, como um maior rendimento de carne magra, com pouco ou nenhum efeito na incidência de carne PSE. Outros estudos indicaram que os animais carregadores $(\mathrm{Nn})$ apresentaram vantagens quando comparados com animais Halotano negativos (NN), como uma melhor eficiência alimentar, maiores rendimentos de carcaça e maior quantidade de carne magra nas carcaças, porém, com uma maior incidência de carne PSE (Leach et al., 1996; Murray et al., 1989).

Fisher et al. (2000) compararam os genótipos nn, Nn e NN. Verificaram que os suínos nn apresentaram menor espessura de gordura $(13,7 \times 16,4 \times$ $17,4 \mathrm{~mm})$, maior AOL $\left(46,4 \times 40,3 \times 35,2 \mathrm{~cm}^{2}\right)$, maior espessura muscular $(64,5$ x $57,9 \times 54,3 \mathrm{~mm}$ ) e maior porcentagem predita de carne magra na carcaça $(69,7 \times 68,1 \times 67,5 \%)$ que os animais Nn e NN. Entretanto, os suínos nn apresentaram uma qualidade de carne inferior aos animais $\mathrm{Nn}$ e $\mathrm{NN}$, com relação ao $\mathrm{pH}_{45 \min }(5,36 \times 5,94 \times 6,22), \mathrm{pH}_{24 h}(5,44 \times 5,60 \times 5,62)$, perda por exsudação $(3,67 \times 2,30 \times 1,53)$ e valores de reflectância $(45,6 \times 43,5 \times 42,0$, para $L^{*} ; 5,81 \times 5,40 \times 5,51$, para $a^{*} ; 7,20 \times 6,67 \times 6,74$, para $\left.b^{\star}\right)$. Fernandez et al. (2002) encontraram valores parecidos quando avaliaram os efeitos do genótipo Halotano e do tratamento pré-abate na qualidade da carne suína. Constataram que o tratamento pré-abate (condições de maior ou de menor estresse) não afetou as características de qualidade de carne e nenhum efeito interativo com o genótipo Halotano foi encontrado. Confirmaram, porém, a influência do gene Halotano nas transformações post-mortem do músculo, onde os suínos homozigóticos positivos (nn) apresentaram maior depleção de glicogênio pré-abate, maior acúmulo de lactato post-mortem e menor valor do $\mathrm{pH}_{45 \min }(5,65 \pm 0,09)$, comparados com suínos $\mathrm{NN}(6,52 \pm 0,05)$, sendo que os animais heterozigóticos $(\mathrm{Nn})$ apresentaram valores intermediários $(6,19 \pm 0,09)$. Estes autores relataram ainda que o músculo Longissimus lumborum dos 
suínos nn apresentou-se mais pálido que o dos animais $N N$ e $N n\left(L^{*}=60,9\right.$; 53,6 e 54,7, respectivamente). Com relação à perda por exsudação, animais nn apresentaram maiores valores que suínos $\mathrm{NN}$, sendo que os animais $\mathrm{Nn}$ mostraram valores intermediários, posição esta mantida também para outras características de qualidade de carne (Fernandez et al., 2002).

Tor et al. (2001) compararam suínos Landrace de genótipos Nn e NN em relação à performance e características de qualidade de carne, de gordura e de carcaça. De acordo com os autores, nenhuma diferença foi observada entre os genótipos $\mathrm{NN}$ e $\mathrm{Nn}$ para crescimento, quantidade de alimento ingerido e eficiência alimentar. Os suínos $\mathrm{Nn}$ apresentaram maior conteúdo de carne magra $(+11,1 \pm 3,7 \mathrm{~g} / \mathrm{Kg})$ e maior proporção de pernil na carcaça $(+2,9 \pm 1,4$ $\mathrm{g} / \mathrm{Kg}$ ). Entretanto, apresentaram menores valores de $\mathrm{pH}_{45 \min }$. Tor et al. (2001) não encontraram diferenças entre os genótipos para gordura muscular e para 0 perfil de ácidos graxos nas gorduras subcutânea e intramuscular. De acordo com os resultados deste estudo, os animais $\mathrm{Nn}$ poderiam alcançar maiores taxas de crescimento e carcaças mais magras que os suínos NN. No entanto, suínos Nn mostraram-se mais propensos a desenvolver carnes PSE.

Bastos et al. (2001) avaliaram o efeito do gene Halotano sobre as características de quantidade e qualidade da carcaça. Relataram que os animais NN, Nn e nn não diferiram no peso da carcaça quente, na espessura de gordura, na profundidade de músculo, na porcentagem de carne magra e na cor do músculo Longissimus dorsi. Entretanto, as variações na cor da carcaça foram menores em animais NN (40,82\%) que em Nn (49,77\%) e nn (53,83\%). Os resultados apresentados pelos autores, neste estudo, indicaram que a presença do gene Halotano em heterozigose ou homozigose recessiva não foi associada a um melhor peso de carcaça podendo, além disso, prejudicar a qualidade da carcaça. Dessa maneira, os autores defendem a idéia de que o uso intencional de animais heterozigóticos ou homozigóticos recessivos não deve ser encorajado. 
Van-Oeckel et al. (2001) avaliaram, através do teste de preferência do consumidor, os genótipos NN e Nn. Relataram que a qualidade de carcaça de ambos os genótipos testados foi similar, enquanto que a acidez, a cor e a perda por exsudação foram inferiores e a perda por cozimento e a dureza foram superiores na carne dos suínos Nn, comparado com suínos NN. Com relação à análise sensorial realizada entre os consumidores, não houve diferença entre a carne de NN e de Nn. Desta forma, os resultados desse experimento sugerem que a eliminação do gene Halotano da população de suínos não garante uma melhor qualidade de carne.

Culau et al. (2002) avaliaram o efeito do gene Halotano nas características de qualidade da carne suína. Os autores observaram diferenças significantes entre animais $\mathrm{Nn}$ e $\mathrm{NN}$ e entre $\mathrm{nn}$ e $\mathrm{NN}$ em relação ao $\mathrm{pH}_{45 \min } \mathrm{e}$ à cor da carne. Relataram que a freqüência de carcaças PSE foi maior em animais de genótipo nn e Nn que em NN (85,71\% , 58,82\% e 36,56\%, baseado no $\mathrm{pH}_{45 \min }$ e $71,43 \%, 47,06 \%$ e $17,20 \%$, baseado na cor). Nesse estudo, o genótipo Halotano não afetou o $\mathrm{pH}_{24 \mathrm{~h}}$ e a temperatura final do músculo. Desta forma, concluíram que com relação ao pH e à cor, a qualidade da carne suína foi inferior nos suínos nn e Nn que nos animais NN.

\subsubsection{Gene $\mathrm{RN}^{-}$}

O gene $\mathrm{RN}^{-}$, identificado na raça Hampshire, está relacionado com a redução do rendimento tecnológico (rendimento Napole ou, em Francês, Napole Rendimento) (Naveau, 1986; Lundström et al., 1996) e com uma menor quantidade de carne magra nas carcaças (Enfält et al., 1997a; Lê Roy et al., 2000). Os efeitos do gene têm sido associados a elevados estoques de glicogênio muscular e um prolongamento no declínio do $\mathrm{pH}$ post mortem (Estrade et al., 1993; Monin e Sellier, 1985; Sayre et al., 1963). Segundo Naveau (1986), a carne de animais que carregam o gene $\mathrm{RN}^{-}$é freqüentemente referida como "carne ácida", devido ao seu baixo pH . O mesmo autor sugeriu a 
existência de um único gene maior para explicar a condição "carne ácida" a qual foi mais tarde confirmada por análise de segregação como um gene com herança dominante (Le Roy et al., 1990). A presença do gen $\mathrm{RN}^{-}$resulta numa redução do pH considerada normal, atingindo valores aceitáveis dentro da primeira hora post mortem $\left(\mathrm{pH}_{45}>6,1\right)$. Entretanto, a queda do $\mathrm{pH}$ muscular tem seu prosseguimento, atingindo valores muito baixos após 24 horas $\left(\mathrm{pH}_{\text {final }}<\right.$ 5,5) estando associada a uma maior reflectância (carne com maior luminosidade) e uma inferior capacidade de retenção de água (Le Roy et al., 2000). Recentemente, foi mostrado que a diferença na CRA de suínos carregadores e não carregadores do gen $\mathrm{RN}^{-}$pode estar associada a uma desnaturação mais pronunciada da cauda da miosina e das proteínas sarcoplasmáticas na carne dos suínos que carregam o gen $\mathrm{RN}^{-}$(Deng et al., 2002).

Enquanto a presença do gene Halotano tem um dramático efeito na CRA, o gene $\mathrm{RN}^{-}$somente aumenta a perda por exsudação em um ponto percentual (Bertram et al., 2000; Enfält et al., 1997b). Em contraste, o rendimento tecnológico é reduzido em 5 a 6 pontos percentuais (Le Roy et al., 2000) na carne de suínos que carregam o gene, comparado com os não carregadores. A título de comparação, o rendimento tecnológico é reduzido a 2 ou 3 pontos percentuais na carne de carregadores do gene Halotano, comparado com os não caregadores (Monin e Sellier, 1985).

Moeller et al. (2002) estudaram os efeitos do gene $\mathrm{RN}^{-}$em suínos Hampshire de terminação, classificados como carregadores $\left(\mathrm{RN}^{\top} / \mathrm{rn}+\right)$ e normais $(r n+/ r n+)$. Segundo os autores, nenhuma diferença entre os genótipos RN//rn+ e rn+/rn+ foi observada com relação à taxa de crescimento, AOL ou espessura de gordura na $10^{\mathrm{a}}$ ou na última costela. Relataram que os lombos $\mathrm{RN} / \mathrm{rn}+$ foram significativamente mais pálidos, com menores valores de $\mathrm{pH}_{24 \mathrm{~h}}$, maior perda por exsudação e perda por cozimento, apresentando, também, menores níveis de gordura intramuscular e maior suculência. 
Moeller et al. (2003), avaliaram os efeitos do gene $\mathrm{RN}^{-}$e compararam as técnicas de genotipagem de DNA e Potencial Glicolítico (PG) utilizadas para classificação de $\mathrm{RN}^{`}$ em suínos de terminação Hampshire. Os resultados de performance e características de carcaça foram os mesmos reportados por Moeller et al. (2002). Segundo os autores, a classificação baseada no potencial glicolítico não classificou corretamente o genótipo $\mathrm{RN}^{-}$, enfatizando a importância da análise direta de DNA para se estimar a freqüência e os efeitos dos genes. Os resultados do genótipo baseado no DNA indicaram claramente que o alelo $\mathrm{RN}^{-}$apresentou efeitos negativos nas medidas de qualidade de carne.

Aproximadamente 20 - 35\% da carne suína é consumida fresca e 65 80\% é processada (Andersen, 1999). Portanto, com o baixo rendimento no processamento da carne de animais carregadores do gen $\mathrm{RN}^{-}$, a indústria de processamento tem um grande interesse em ser capaz de discriminar entre carne suína dos dois genótipos $\left(\mathrm{RN}^{-}\right.$e $\mathrm{rn+}$ ) (Josell et al., 2000). Conseqüentemente, as empresas de genética estão discutindo a eliminação do gene $\mathrm{RN}^{-}$de suas linhas de seleção, similar ao que foi decidido a respeito do gene Halotano.

\subsubsection{Efeitos poligênicos}

Com exceção dos genes maiores mencionados acima, a herdabilidade da maioria dos atributos referentes à qualidade de carne é de baixa a moderada (0,15 - 0,30) (de Vries et al., 1994; Sellier e Monin, 1994; Sosnicki et al., 1998), exceto para o conteúdo de gordura intramuscular $(0,40$ - 0,50) (Sellier e Monin, 1994), que, normalmente, está associado com a melhora da qualidade sensorial.

Embora a herdabilidade da porcentagem de gordura intramuscular e tecido gorduroso seja alta (0,50 e 0,69, respectivamente), a correlação genética 
entre eles é muito baixa (0,11; Wood, 1990). Isto sugere que a seleção para o aumento da gordura intramuscular nas carcaças magras deva ser possível.

A herdabilidade do $\mathrm{pH}_{24 \mathrm{~h}}$ tem sido mostrada ser aproximadamente 0,21 (varia de 0,07-0,39; Sellier, 1998). Entretanto, estudos recentes têm mostrado que o $\mathrm{pH}_{24 h}$ nas populações livres do gene Halotano e do gene $\mathrm{RN}^{-}$pode não ser o indicador ideal da qualidade de carne. D'Souza e Mullan (2002) reportaram um maior $\mathrm{pH}_{24 \mathrm{~h}}$ em uma linha Duroc 50\% comparado com uma linha Duroc $<25 \%$, embora a CRA tenha sido menor na primeira linha. Schäfer et al. (2001) reportaram que o $\mathrm{pH}_{24 \mathrm{~h}}$ explica somente $4 \%$ da variação na CRA na carne do cruzamento de suínos Duroc, Landrace e Yorkshire. Em contraste, o $\mathrm{pH}_{1 \mathrm{~h}}$ medido no mesmo material explica $72 \%$ da variação na CRA.

A seleção para se melhorar a performance dos suínos pode resultar em efeitos negativos nos atributos da qualidade de carne (Cameron, 1990; de Vries et al., 1994; Hovenier et al., 1992), até mesmo nas linhas de seleção livres do gene Halotano. Oksbjerg et al. (2000) comparou duas diferentes linhas de seleção de Landrace dinamarquês representando o potencial de crescimento dos anos 1976 e 1995, respectivamente. A taxa de crescimento muscular foi dramaticamente aumentada devido ao aumento do número de fibras musculares e da proliferação de células satélites durante o período de seleção. Entretanto, a seleção resultou em uma carne significativamente mais luminosa e menos vermelha e com um conteúdo de pigmento menor comparado com a linha correspondente ao ano 1976 (Rosenvold et al., 2003). Similarmente, Barton - Gade (1990) reportou que o conteúdo de pigmento do músculo Longissimus dorsi e do músculo Bíceps femoris diminuiu entre o início e o final da década de 80 nas centrais de teste de performance dinamarquesa. Além disso, a herdabilidade do conteúdo de pigmento nas amostras post mortem, mostraram ser tão altas quanto 0,65 como citado por Oksbjerg et al. (2001). Lonergan et al. (2001) compararam uma linha de suínos Duroc selecionados para aumento na eficiência de carne magra com uma linha de seleção contemporânea. A performance melhorou na linha de seleção para deposição 
de carne magra, mas o $\mathrm{ph}_{45 \mathrm{~min}}$ foi menor e a CRA reduziu, comparado com a linha de seleção contemporânea.

\subsubsection{Nutrição}

Os suínos são animais monogástricos e muitos componentes da dieta são prontamente transferidos dos alimentos para os tecidos muscular e adiposo, os quais, posteriormente, afetam a qualidade da carne suína. Isto é valido para a composição de ácidos graxos da dieta (Wood \& Enser, 1997), para a composição de vitamina e sais minerais, como por exemplo, a suplementação com vitamina E (Buckley et al., 1995) e outros ingredientes fornecidos para aumentar os compostos responsáveis pelo aroma e sabor desagradáveis, como a farinha de peixe (Hertzman et al., 1988). Além disso, tem sido mostrado que os estoques de glicogênio muscular no momento do abate podem ser manipulados através da alimentação (Rosenvold et al., 2001a; Rosenvold et al., 2001b; Rosenvold et al., 2002b) influenciando, desta maneira, a taxa de queda do $\mathrm{pH}$ e a qualidade tecnológica da carne suína (Rosenvold et al., 2003).

\subsubsection{Manipulação dos níveis de glicogênio muscular}

A utilização de grandes quantidades de carboidrato digerível na dieta tem sido investigada com o objetivo de reduzir ou superar o problema de qualidade de carne inferior associada com alto $\mathrm{pH}_{24 \mathrm{~h}}$, comumente conhecido como carne escura, firme e ressecada na superfície (DFD). A carne DFD é causada pela restrita formação de lactato post mortem nos músculos com baixos níveis de glicogênio e fosfato creatina na hora do abate (Bendall, 1973; Hamm, 1960), como conseqüência, por exemplo, do longo período de estresse

pré abate, incluindo as brigas entre os animais. A dieta com altos níveis de sacarose ou outra fonte de carboidrato digerível, poucos dias antes do abate ou 
durante a noite na pocilga de repouso, pode aumentar o suprimento de glicogênio muscular e, assim, reduzir o $\mathrm{pH}_{24 h}$ (Briskey et al., 1959; Briskey et al., 1960; Fernandes et al., 1979; Sayre et al., 1963). Dados de Fernandez et al. (1992) sugerem que as observações acima são efeitos provenientes de um período curto, já que o jejum na noite anterior ao abate removeu qualquer efeito da dieta com açúcar. Informa-se, outrossim, que o último estudo foi conduzido utilizando-se cruzamento de suínos Hampshire, conhecidos por apresentarem uma alta freqüência do gen $\mathrm{RN}^{-}$. Como Pethick et al. (1997) ressaltou em sua revisão sobre a manipulação nutricional da qualidade de carne, a incidência de carne DFD pode diminuir, mas é provável que a incidência de carne PSE aumente, especialmente nos animais carregadores do gen Halotano, quando é introduzido o açúcar na dieta. Há evidências que confirmam esse fato, ou seja, a condição PSE favorecida pelo alto teor de energia no momento da sangria (Silveira, 1997).

A administração de dietas ricas em gorduras (aproximadamente 1718\%) e proteínas (22 - 24\%) em combinação com um baixo conteúdo de carboidrato digerível (<5\%) durante 3 dias antes do abate mostrou reduzir as reservas de glicogênio muscular no músculo Longissimus dorsi, sem influenciar a performance do animal (Rosenvold et al., 2001 a, 2001 b, 2002 b). A combinação de uma pequena quantidade de carboidrato digerível com um elevado teor de gordura nas dietas é indicada por causar o efeito de redução do glicogênio muscular. Esses resultados são sustentados por um estudo onde foram obtidos resultados similares sobre a padronização da dieta com aumento no conteúdo de gordura (Lauridsen et al., 1999). A redução no conteúdo de glicogênio muscular melhorou a CRA dos músculos Longissimus dorsi, Bíceps femoris e Semimembranosus (Rosenvold et al., 2001 a, 2002 b). Esta não foi conseqüência de um maior $\mathrm{pH}_{24 h}$, mas de um maior $\mathrm{pH}_{45 \text { min }}$, indicando, assim, mudanças no metabolismo do glicogênio muscular (Rosenvold et al., 2003).

Recentemente, Bee (2001) mostrou que uma redução no conteúdo de carboidrato digerível (45-36\%), com um posterior aumento no conteúdo de 
gordura para manter as dietas isoenergéticas, não foi suficiente para causar qualquer diferença nas reservas de glicogênio post mortem no músculo Longissimus dorsi ou na porção vermelha do músculo Semitendinosus. Nem o $\mathrm{pH}_{24 \mathrm{~h}}$ nem a CRA foram alterados no músculo Longissimus dorsi, embora a CRA no Semitendinosus melhorou na fêmea, fato este não observado nos machos. Portanto, para se obter uma redução no conteúdo de glicogênio muscular, como observado por Rosenvold et al. (2001 a, 2001 b, 2002 b), a taxa entre gordura e carboidrato digerível deverá ser maior. Isto é, mais gordura e menos carboidrato digerível. Como suporte a esta teoria, Leheska et al. (2002) não encontraram nenhum efeito no potencial glicolítico post mortem ou melhora na qualidade de carne pela administração de uma baixa quantidade de carboidrato digerível/ alta proteína na dieta, durante as últimas duas semanas que precederam o abate.

\subsubsection{Gorduras na dieta}

Por muitos anos existiu um grande interesse em se modificar a composição da gordura animal através da alimentação para satisfazer as recomendações das dietas para humanos, isto é, uma ótima proporção entre ácidos graxos saturados, monoinsaturados e poliinsaturados (Jakobsen, 1999). Entretanto, a carne com um elevado conteúdo de ácidos graxos poliinsaturados pode adquirir características, como a flacidez, que empobrecem sua qualidade (Cameron et al., 1999; Warnants et al., 1998). Um alto conteúdo de ácidos graxos poliinsaturados aumenta a susceptibilidade de ocorrer oxidação, reduzindo, assim, a vida de prateleira do produto (Allen \& Foegeding, 1981; Sheard et al., 2000). Finalmente, existe uma grande correlação inversa entre a quantidade de gordura e a concentração de ácidos graxos poiinsaturados (Wood et al., 1997). Portanto, como conseqüência dos esforços para se obter carcaças magras, a concentração de ácidos graxos poliinsaturados aumentou e 
ressaltou a instabilidade oxidativa, especialmente durante o processamento (Wood, 1997).

A respeito dos problemas acima mencionados, é possível melhorar o valor nutricional da carne suína através de corretas estratégias de alimentação, sem afetar desfavoravelmente a oxidação lipídica (Riley et al., 2000; Sheard et al., 2000). A fonte de gordura da dieta dos suínos está sendo substituída de animal (mais gordura saturada) para mais gordura vegetal (mais gordura insaturada). Esta mudança pode afetar a qualidade da gordura da carne suína. A utilização de gordura animal na terminação pode ser uma solução para aumentar a firmeza da gordura da carne suína, como sugerido por Warnants et al. (1999).

Recentes enfoques sobre os efeitos das dietas lipídicas têm aumentado o interesse por ácidos graxos específicos ou essenciais, dos quais o ácido linolêico conjugado (ALC) tem atraído maior atenção (Rosenvold et al., 2003). Os efeitos benéficos do ALC foram primeiramente descobertos na metade da década de 80 (Dunshea et al., 1999). Nos suínos, o ALC melhora a performance do animal, reduz a deposição de gordura e aumenta o conteúdo de carne magra (D'Souza et al., 2002; Thiel - Cooper et al., 2001; Wiegand et al., 2001).

Com relação à qualidade de carne, ALC aumenta a proporção de gordura saturada/insaturada nos músculos, tecido adiposo e gordura intramuscular e melhora a firmeza da barriga (Dugan et al., 1999; Joo et al., 2002; Thiel - Cooper et al., 2001; Wiegand et al., 2001). Além disso, D'Souza et al. (2002) relataram que o $\mathrm{pH}_{24 h}$ aumentou e houve melhora na CRA, mas uma qualidade degustativa inferior, isto é, sabor, maciez, suculência, como resultado da suplementação de ALC na dieta dos suínos. 


\subsubsection{Suplementação com vitamina E e outros antioxidantes na dieta}

A utilização de vitamina $E$ acima dos níveis exigidos na dieta (200mg/Kg de alimento), protege contra a oxidação lipídica em carne suína fresca e outros produtos derivados de carne suína (Asghar et al., 1991; Buckley, et al., 1995; Lauridsen et al., 1999). A oxidação lipídica, juntamente com a deterioração microbiológica, é a causa primária da perda de qualidade da carne suína determinando, desta maneira, a vida de prateleira dos produtos da carne suína. A oxidação leva a produção de sabor e odores indesejáveis e a formação potencial de compostos tóxicos. A taxa e a extensão da oxidação lipídica são dependentes da concentração de vitamina $\mathrm{E}$ e da composição de ácidos graxos da carne (Buckley et al., 1995).

Acredita-se que a taxa de descoloração da carne depende tanto do processo oxidativo quanto dos sistemas de redução da metamioglobina (Faustman \& Cassens, 1990). Alguns estudos têm relatado a melhora na estabilidade da cor da carne suína após a suplementação com vitamina $E$ (Asghar et al., 1991). Entretanto, diversos estudos não encontraram qualquer efeito desta suplementação na estabilidade da cor da carne suína (Cannon et al., 1996; Phillips et al., 2001; Rosenvold et al., 2003).

Em geral, acredita-se que a suplementação com vitamina $E$ melhore a CRA na carne suína. Asghar et al. (1991) e Cheah et al. (1995) sugeriram que a vitamina $E$ pode preservar a integridade das membranas das células musculares pela prevenção da oxidação dos fosfolipídios da membrana durante o período de estocagem. Cheah et al. (1995) mostraram que a suplementação

supra-nutricional de vitamina $\mathrm{E}$ com $1000 \mathrm{mg} / \mathrm{Kg}$ de alimento diminuiu a incidência de carne PSE, sendo mais pronunciada em carregadores do gen Halotano. Finalmente, tem sido mostrado que a vitamina $\mathrm{E}$ aumenta as reservas de glicogênio muscular em suínos (Lauridsen et al., 1999; Rosenvold et al., 2002 b) e, em um desses estudos, diminuiu a CRA em animais que foram estressados imediatamente antes do abate. Isto tem sido vinculado a maiores 
reservas de glicogênio muscular nos músculos pré abate (Rosenvold et al., 2002 b).

Hasty et al. (2002) pesquisaram o efeito da suplementação de vitamina $E$ na qualidade da carne de dois genótipos (Berkshire e Hampshire) que apresentam distinções nas características de qualidade de carne. Estes autores reportaram que os suínos pertencentes ao genótipo Berkshire tiveram maior espessura de gordura (34.1x $21.1 \mathrm{~mm}$ ), menor AOL (37.6 vs $46.3 \mathrm{~cm} 2)$ e menor porcentagem de carne magra (53.0 vs 55.8) que os animais Hampshire. Informaram ainda que a suplementação com vitamina E não resultou em efeitos na composição da carcaça e que o músculo Longissimus dorsi dos suínos de terminação Hampshire mostraram uma redução do $\mathrm{pH}_{24 h}$ (5.64 vs 5.91), maior perda por exsudação (92.2 × $66.3 \mathrm{mg})$, e maiores valores de $L^{*}(52.6 \times 48.6)$, a* (8.9 x 7.5), e b* $(6.9 \times 5.2)$ comparado com suínos de terminação Berkshire. Hasty et al. (2002) relataram que a vitamina $E$ não teve efeito no $\mathrm{pH}$, na temperatura, na perda por exsudação e nos valores de $L^{*}$ ou de $a^{*}$, mas tendeu a aumentar linearmente os valores de $b^{*}$.

Baseado nas informações existentes sabe-se que há um nível de suplementação de vitamina E mais apropriado, onde a melhoria da cor e a estabilidade oxidativa são obtidas antes de ocorrer uma eventual elevação das reservas de glicogênio muscular e de um aumento na formação de exsudato, que são indesejáveis.

\subsubsection{Redução do estresse através da alimentação}

Qualquer componente de um alimento que direta ou indiretamente reduza as respostas ao estresse pode reduzir os efeitos na qualidade da carne suína associados ao estresse. A resposta imediata aos fatores de estresse é a liberação de neurotransmissores no cérebro, os quais estimulam o sistema nervoso e liberam hormônios do estresse no sangue. Estes podem estimular 
negativamente o metabolismo muscular em relação à qualidade de carne (Rosenvold et al., 2003).

D'Souza et al. (1998 c) reportaram que o magnésio neutraliza os efeitos da catecolamina em situações de estresse. O efeito primário do magnésio parece ser uma redução na estimulação neuromuscular devido aos efeitos do magnésio como antagonista do cálcio. Muitos estudos mostraram que a suplementação de magnésio na dieta, anteriormente ao abate, melhora a qualidade da carne suína, resultando em melhor CRA e carne mais escura (Apple et al., 2000; D'Souza et al., 1998 a; D'Souza et al., 1999). Isto é verdade para a suplementação tanto em período longo (de um peso vivo de 25 a $30 \mathrm{Kg}$ ) como em um período curto (últimos 2 - 5 dias antes do abate). Entretanto, existem algumas discrepâncias com relação ao efeito da suplementação de magnésio na dieta quando comparados os carregadores e os não carregadores do gen Halotano (Apple et al., 2000; Caine et al., 2000).

Apple et al. (2002) investigaram os efeitos da suplementação com magnésio na dieta de suínos, durante os períodos de crescimento e terminação, na performance e nas características de qualidade da carne de suínos carregadores do gene Halotano ( $\mathrm{Nn}$ ) e de suínos homozigóticos negativos (NN). Os autores relataram que os animais NN tiveram maior ganho de peso diário durante as fases de crescimento e terminação que os animais Nn. Observou-se que as carcaças de suínos $\mathrm{Nn}$ foram mais magras e apresentaram maior peso muscular que as carcaças de suínos homozigóticos negativos. Por outro lado, uma maior porcentagem de carcaças de animais $\mathrm{Nn}$ receberam pontuações para cor característica de condição PSE. Os autores concluíram que embora tenha havido efeitos distintos nos genótipos com relação à performance e às características de carcaça, a suplementação com magnésio nas dietas por um longo período não demonstrou efeitos benéficos ou prejudiciais na qualidade da carne suína ou no rendimento de carcaça.

Em estudo realizado por Adeola et al. (1992), a concentração do neurotransmissor serotonina, derivado do triptofano, apresentou redução nos 
suínos que exibiam um certo grau de estresse. Segundo os mesmos autores, um aumento na quantidade de triptofano ingerido na dieta leva a um aumento na síntese de serotonina no cérebro de várias espécies.

Como mencionado anteriormente, estratégias de alimentação para a redução do estresse têm potencial como uma ferramenta para melhorar a qualidade da carne suína.

\subsubsection{Creatina}

A qualidade tecnológica da carne suína tem sido avaliada após a suplementação com creatina monohidratada no período até o abate (Berg et al., 2001; O'Quinn et al., 2000 ; Stahl et al., 2001). Em suínos, um aumento nas reservas de energia deveria retardar o metabolismo do glicogênio post mortem e, então, afetar a queda do pH muscular. Estudos demonstraram que a suplementação com creatina monohidratada por cinco dias melhorou o ganho de peso, reduziu a taxa de declínio do $\mathrm{pH}$ post mortem e diminuiu a perda por exsudação (Berg \& Allee, 2001; Maddock et al., 2000; Stahl et al., 2001). Além disso, a incidência de carne PSE foi significativamente reduzida em suínos suplementados com creatina (Maddock et al., 2000). Entretanto, o prolongamento da suplementação por um período de 10 a 15 dias apresentou efeitos negativos na qualidade tecnológica da carne suína (Stahl et al., 2001). Por outro lado, O'Quinn et al. (2000) não encontraram efeito algum da creatina monohidratada na performance ou na qualidade de carne. O efeito de redução de carne PSE através da administração da creatina, observado por Maddock et al. (2000), poderia ser explicado pelo fato de que metade dos suínos eram carregadores do gen Halotano, e o efeito dessa suplementação é maior nos suínos carregadores do gen. Entretanto, num estudo consecutivo, Maddock et al. (2002) não encontraram efeito significativo da suplementação com creatina monohidratada na qualidade tecnológica da carne suína. 


\subsubsection{Sistemas de produção}

A composição de ácidos graxos da carne de suínos criados em sistema extensivo, incluindo os sistemas de produção de suíno orgânico, tem sido reportada ser mais insaturada quando comparada com a carne de suínos criados no sistema intensivo (Nilzen et al., 2001), aumentando o risco de oxidação lipídica e originando uma gordura mais mole, levando a uma qualidade inferior (Warnants et al., 1996; Warnants et al., 1998). Níveis de vitamina $E$ considerados altos ou baixos foram encontrados na carne de animais submetidos ao sistema extensivo de produção, o que indica que não se pode esperar que este fator compense o elevado nível de ácidos graxos poliinsaturados ocasionando a diminuição da estabilidade oxidativa da carne (Nilzén et al., 2001).

Investigações realizadas têm mostrado que os sistemas de criação extensivo e orgânico aumentaram o rendimento de carne magra (Sather et al., 1997; Sundrum et al., 2000) e aumentaram também o valor da carcaça devido ao maior peso de lombo, pernil e paleta, comparado com suínos criados em regime de confinamento (Sather et al., 1997). Porém, esses animais também apresentaram uma quantidade maior de gordura intramuscular (Sundrun et al., 2000).

Recentemente, Beattie et al. (2000) mostraram que o sistema de produção extensivo comparado com o intensivo (piso rígido e espaço mínimo recomendado) resultou em carne suína com melhor qualidade de carne, como demonstrado pela diminuição da perda de água durante o cozimento.

Conforme afirmado por Sanchai - Jarurasitha et al. (1998), as diferenças existentes nas carcaças e nas carnes dos animais provenientes desses novos sistemas de produção não são devido ao sistema de produção isoladamente, sendo que os fatores genéticos, a alimentação e o manejo pré abate são igualmente importantes. Assim, a introdução de "novos" sistemas de 
produção leva ao estabelecimento de programas de qualidade garantida, os quais podem assegurar que as exigências dos consumidores sejam satisfeitas.

\subsubsection{Jejum}

Classificado como o primeiro ponto crítico do transporte, o tempo de jejum influencia as outras condições do estresse no transporte, podendo ser responsável pelo aumento total das perdas.

Em muitos países, 12-15 horas de jejum pré- abate consiste numa prática comum para se reduzir o risco de contaminação microbiana cruzada durante o abate. Além disso, sabe-se que os suínos não devem ser alimentados imediatamente antes do transporte, pois animais com os intestinos repletos apresentam maior mortalidade durante o transporte (Warris, 1994).

Tem-se investigado o jejum como uma maneira de se reduzir as reservas de glicogênio muscular em suínos no momento do abate, a fim de se aumentar o $\mathrm{pH}_{24 \mathrm{~h}}$, melhorando, assim, a CRA e a cor (Rosenvold et al., 2003). Experimentos realizados por Warris (1982) e Wittmann et al. (1994) indicaram que o jejum prolongado (24 horas) reduz a incidência de PSE e melhora a cor, maciez e capacidade de retenção de água da carne. Os autores recomendaram períodos de jejum entre 16 e 24 horas objetivando maximizar o rendimento da carcaça. Entretanto, longos períodos de jejum implicam em perda de peso, que

varia de 0,12 a 0,20\% por hora e é causada, inicialmente, pela excreção de fezes e urina. Perdas de peso nas carcaças começam entre 9 e 18 horas após a última alimentação. Dependendo do fator estressante adicional, as perdas variam entre 0,06 e 0,14\% por hora, durante o período de 48 horas de jejum (Warris, 1993). A reserva do glicogênio muscular é reduzida em 10\% do nível considerado normal para o jejum correspondente a 21 horas. Dessa forma, Warris e Bevis (1987) recomendam, para jornadas que excedam este tempo, a inclusão da alimentação e de um período de descanso antes de proceder ao abate dos suínos (Gregory, 1994). 


\subsubsection{Manejo pré-abate}

O manejo pré-abate inclui a mistura de animais de grupos diferentes, transporte e tempo de repouso na pocilga do abatedouro. Estas práticas de manejo podem induzir não só o estresse físico, mas também o psicológico. $O$ estresse pré-abate influencia tanto o bem estar como a qualidade da carne, podendo afetá-la negativamente (Fernandes et al., 1979).

O estresse pré-abate pode ser grosseiramente dividido em estresse de período longo, como o manejo na ganja, a mistura, o embarque e o transporte dos animais e estresse de período curto, incluindo as condições predominantes na pocilga de repouso e a condução até o abate. Esses dois tipos de estresse não deveriam ser considerados como duas coisas separadas, embora principalmente o estresse de período longo leve à qualidade de carne associada com carne DFD, enquanto que o estresse de período curto leve à qualidade associada com carne PSE ou RSE (vermelha, flácida e exsudativa).

A mistura de grupos de animais deveria ser evitada durante o manejo pré-abate (Guise \& Penny, 1989). Suínos em grupos desenvolvem hierarquias sociais, as quais são disputadas quando animais de grupos diferentes são misturados. Os indivíduos dos grupos misturados freqüentemente brigam para estabelecer uma nova ordem de dominância (Warriss, 1998). Isso leva a lacerações de pele, as quais podem ser severas, sendo um sério problema comercial, pois diminui o valor da carcaça (Faucitano, 2001). Além disso, ao brigarem, os animais mostraram um aumento na depleção de glicogênio nos músculos e, conseqüentemente, um maior $\mathrm{pH}_{24 h}$ na carne (Warriss \& Brown, 1985; Warriss et al., 1998 a). Warriss \& Brown (1985) encontraram que o $\mathrm{pH}_{45 \min }$ não foi afetado pelas brigas. Se a mistura é inevitável, o que acontece em muitos casos, a redução no tamanho dos grupos pode ser uma maneira de se reduzir a agressão. Pesquisas empreendidas nesta área mostraram que grupos com 15 animais levaram a uma diminuição da agressão e promoveram um comportamento mais tranqüilo comparado com grupos maiores, mesmo 
quando os grupos foram compostos por animais misturados (Barton - Gade, 1997).

Gregory (1998) relatou que alguns suínos halotano positivos (nn) que são misturados nas pocilgas de espera dos abatedouros correm o risco de morrerem em conseqüência de uma crise de estresse. Por outro lado, aqueles que sobreviverem ao estresse provocado pela mistura dos animais e forem abatidos em condições de manejo consideradas normais, podem apresentar uma qualidade de carne ligeiramente melhor que a dos animais nn que não foram submetidos à mistura de grupos (Murray, 1994). Isto ocorre, pois os níveis de glicogênio muscular são reduzidos pelo exercício realizado pelos animais durante o processo de mistura, limitando a taxa de queda do $\mathrm{pH}$ muscular. Na realidade, os músculos susceptíveis à carne PSE acabam apresentando a anomalia DFD. Gregory (1998) apresentou as combinações de genótipo e qualidade de carne que podem ocorrer num mesmo animal, como mostra a Tabela 1.

Tabela 1. Relações entre genótipo, glicogênio muscular e qualidade de carne

\begin{tabular}{ccc}
\hline & $\begin{array}{c}\text { nível de glicogênio } \\
\text { muscular }\end{array}$ & \\
genótipo & no momento do abate & qualidade de carne \\
\hline $\begin{array}{ccc}\text { Sensível ao estresse } \\
\text { (ex: Pietráin) }\end{array}$ & alto & PSE \\
& médio & PSE ou normal \\
Resistente ao estresse & baixo & DFD \\
(ex: Large Withe) & alto & normal \\
& médio & normal \\
& baixo & DFD \\
\hline
\end{tabular}

Fonte: Gregory (1998)

a Suínos sensíveis ao estresse são halotano positivos (nn), susceptíveis à hipertermia malignante, predispostos a apresentarem mortes induzidas pelo estresse

${ }^{\text {b }}$ Suínos resistentes ao estresse (NN) são resistentes às complicações acima 
É geralmente aceito que o embarque dos animais na granja e o desembarque no abatedouro são as etapas mais estressantes do transporte (Barton-Gade, 1997). Quando o suíno é conduzido fora das instalações de origem, seu batimento cardíaco pode dobrar em relação ao período de descanso (80 batidas/minuto). Em condições inadequadas, a condução do animal até o veículo do embarque pode induzir um acréscimo adicional no batimento cardíaco (250 batidas/minuto). Quando acomodados no interior da carroceria, esse batimento reduz consideravelmente (150 batidas/minuto) e continua a cair, ligeiramente, durante o transporte. Segundo Schütte et al. (1994), transcorridos cerca de 100 minutos do início do transporte, o batimento cardíaco permanece entre 20 a 50 batidas/minuto acima do valor de descanso. $O$ estresse do desembarque é semelhante ao do embarque e, nas duas situações, tornam-se necessárias adequações das plataformas, na unidade de produção e de recepção no abatedouro.

Durante o transporte, a qualidade do veículo, a ventilação, as densidades e as distâncias de viagem são importantes para o nível de estresse induzido nos animais (Barton - Gade, 1997; Warriss, 1998 e Faucitano,2001). Partindo-se do princípio que os animais não se apresentam totalmente tranqüilos durante o transporte, viagens mais curtas são plenamente justificadas. Portanto, a distância percorrida é menos importante que o tempo de transporte, uma vez que os eventos que afetam o tempo (coleta de animais nas diversas granjas, trafego lento, engarrafamento, etc) podem ter um efeito mais adverso no estresse do animal. Barton - Gade (1985) constataram que a incidência de PSE foi mais elevada em transportes de curta duração (30 minutos) e mais baixa em transportes mais longos (80 minutos). A legislação da União Européia não fixa tempo máximo de transporte, apenas intervalos após os quais água e alimento devem ser fornecidos aos suínos, isto é, após 8 e 24 horas, respectivamente (Barton-Gade, 1985).

Tem sido mostrado que o tempo de espera na pocilga do abatedouro afeta os níveis de estresse em suínos (Faucitano, 2001). Um ótimo tempo de 
pocilga parece ser em torno de $2-3$ horas (van der Wal et al., 1997 e Warriss et al., 1998 b). Após aproximadamente 2 horas de repouso, os animais tranqüilizam-se, ocorrendo a estabilização do metabolismo, sistema circulatório e termoregulador (van der Wal et al., 1997; van der Wal et al., 1999). Entretanto, durante longos períodos de permanência na pocilga do abatedouro, ocorre um aumento da atividade exploratória dos animais. A proporção de danos na pele e de carne DFD, devido às brigas e à depleção de glicogênio muscular, respectivamente, aumentam (Nanni et al., 2002; Warriss et al., 1998 b). O abate realizado imediatamente após a chegada ao abatedouro ou após pouco tempo de espera pode aumentar a proporção de carne PSE (Eikelenboom \& Bolink, 1991). Entretanto, o tempo ótimo de espera na pocilga de repouso depende muito das condições encontradas neste ambiente (por exemplo, o tamanho do grupo), da mistura de animais de diferentes grupos e da intensidade de estresse enfrentado pelos suínos durante o transporte. Aaslyng \& Barton - Gade (2001) mostraram que a qualidade da carne suína de uma população livre do gen Halotano foi independente do tempo de espera na pocilga, quando os animais foram expostos a baixo nível de estresse no manejo pré-abate. A Tabela 2 ilustra o efeito do genótipo e do tempo de espera nas pocilgas do abatedouro nas características de qualidade de carne PSE (de Smet et al., 1996, citado por Gregory, 1988).

Costa et al. (2002) avaliaram o efeito de dois diferentes tempos de espera na pocilga ( 2 e 22 horas antes do abate) na qualidade de carne de suínos com diferentes genótipos Halotano, previamente submetidos a tratamentos pré-abate controlados. Os autores relataram que o tempo maior de espera não afetou negativamente as características de carcaça e reduziu a incidência de carne PSE, sem aumentar a ocorrência de carne DFD. Entretanto, aumentou seriamente a quantidade de danos na pele devido às brigas, resultado do longo jejum. 
Tabela 2. Efeito do genótipo e tempo de espera nas pocilgas do abatedouro, nas características de carne PSE

\begin{tabular}{|c|c|c|c|c|}
\hline Genótipo & $\begin{array}{l}\text { Tempo de } \\
\text { espera (h) }\end{array}$ & $\begin{array}{c}\mathrm{pH}_{40 \text { min }} \text { no } \\
\text { lombo }\end{array}$ & $\begin{array}{c}\text { valor de } \\
L^{*}\end{array}$ & $\begin{array}{c}\text { Perda por } \\
\text { Exsudação } \\
\left(\mathrm{g} . \mathrm{Kg}^{-1}\right)\end{array}$ \\
\hline \multirow{4}{*}{ NN } & $<1 \mathrm{~h}$ & $6,25 \pm 0,04$ & $50,7 \pm 0,06$ & $42 \pm 4^{b}$ \\
\hline & $2 h-3 h$ & $6,27 \pm 0,04$ & $50,5 \pm 0,05$ & $37 \pm 4^{b c}$ \\
\hline & $4 h-5 h$ & $6,23 \pm 0,04$ & $50,1 \pm 0,05$ & $34 \pm 4^{c}$ \\
\hline & $<1 h$ & $6,03 \pm 0,03^{b}$ & $51,2 \pm 0,04$ & $48 \pm 3$ \\
\hline \multirow[t]{3}{*}{$\mathrm{Nn}$} & $2 h-3 h$ & $6,11 \pm 0,03^{b c}$ & $50,7 \pm 0,04$ & $46 \pm 3$ \\
\hline & $4 h-5 h$ & $6,15 \pm 0,03^{c}$ & $51,0 \pm 0,04$ & $44 \pm 3$ \\
\hline & $<1 h$ & $5,69 \pm 0,06^{b}$ & $56,8 \pm 0,08^{b}$ & $70 \pm 6^{b}$ \\
\hline \multirow[t]{2}{*}{$\mathrm{nn}$} & $2 h-3 h$ & $5,72 \pm 0,06^{b}$ & $54,7 \pm 0,08^{c}$ & $60 \pm 6^{b c}$ \\
\hline & $4 h-5 h$ & $5,88 \pm 0,06^{c}$ & $53,0 \pm 0,08^{d}$ & $55 \pm 5^{c}$ \\
\hline
\end{tabular}

Fonte: De Smet et al. (1996)

a-d Médias numa coluna sem uma letra sobrescrita comum, foram significativamente diferentes $(p=0,05)$

Um curto período de estresse imediatamente antes do abate resulta em valores mais baixos de $\mathrm{pH}$ e temperaturas mais altas no início do post mortem (Henkel et al., 2000; Rosenvold et al., 2001 a, 2001 b; Stoier et al., 2001; van der Wal et al., 1997; van der Wal et al., 1999). Na verdade, o estresse pré-abate reduz o pH no músculo enquanto o suíno ainda está vivo (Henckel et al., 2000). As condições indesejáveis de $\mathrm{pH}$ e temperatura, encontradas na carne de animais estressados, normalmente levam a uma inferior CRA (D'Souza et al., 1998 c; Henckel et al., 2000; Rosenvold et al., 2001 a; 2002 b; Stoier et al., 2001; van der Wal et al., 1999). Isto indica que mesmo nas populações de suínos livres do gen Halotano, o pH e a temperatura anteriores ao post mortem são de importância para a formação de exsudação, como mostrado em um estudo dos fatores de importância para a CRA na carne suína (Schafer et al., 
2002). Neste estudo, foi reportado que o $\mathrm{pH}_{24 \mathrm{~h}}$ esclareceu somente $2 \%$ da variação da perda por exsudação. Além disso, o $\mathrm{pH}_{24 \mathrm{~h}}$ foi 0,1 a 0,2 unidades maior nos suínos estressados antes do abate em relação aos não estressados, embora a CRA foi menor nos animais estressados (Stoier et al., 2001; van der Wal et al., 1999). Os maiores valores de $\mathrm{pH}_{24 \mathrm{~h}}$ observados nos suínos estressados no pré-abate são, provavelmente, uma conseqüência dos baixos níveis de fosfato creatina no momento do abate. Baixos níveis de fosfato creatina resultam num aumento do metabolismo do glicogênio durante o abate, devido a uma redução na concentração de ATP, comparado com os suínos não estressados, os quais são capazes de usar as reservas de fosfato creatina durante o abate (Henckel et al., 2002). Os resultados ilustram o fato de que o $\mathrm{pH}_{24 h}$ é um pobre indicador da CRA em populações livres dos genes Halotano e $\mathrm{RN}^{-}$. Além disso, a cor e a estabilidade da cor são negativamente afetadas pelo estresse de curto período pré-abate (van der Wal et al., 1999).

Barton Gade (1997) e Stoier (2001) desenvolveram um sistema de redução de estresse no manejo pré abate durante a espera e alguns minutos antes da insensibilização. Nesse sistema, os suínos são mantidos em grupos de 15 animais durante a espera e na condução. Antes da insensibilização, cada grupo é dividido em três grupos de cinco animais, destinados à insensibilização com $\mathrm{CO}_{2}$. A redução do estresse pré-abate resulta numa temperatura da carcaça mais baixa imediatamente pós - abate, a qual exerce um efeito positivo na CRA (Stoier et al., 2001).

\subsubsection{Métodos de insensibilização}

Constitui-se numa necessidade legal em relação ao bem-estar animal, de acordo com a legislação européia, que todos os animais abatidos tornem-se instantaneamente insensíveis e que permaneçam neste estado até que exista uma completa perda de resposta cerebral devido à exsanguinação. A indústria considera a qualidade da carne e a presença de hemorragias e ossos 
fraturados quando avalia as vantagens e desvantagens dos diferentes sistemas de insensibilização. No caso dos suínos, os dois métodos de mais usados são o dióxido de carbono $\left(\mathrm{CO}_{2}\right)$ e a insensibilização elétrica.

Em geral, os músculos de suínos insensibilizados eletricamente apresentam um declínio mais rápido de $\mathrm{pH}$ no início do post mortem e uma inferior CRA, comparados com os de suínos submetidos à insensibilização gasosa, onde $0 \mathrm{pH}_{24 h}$ não é afetado (Channon et al., 2000; Channon et al., 2002). Isto indica que a insensibilização elétrica, comparada com a insensibilização com $\mathrm{CO}_{2}$ leva a um maior estresse fisiológico nos suínos e aumenta a taxa do metabolismo energético post mortem, devido ao aumento da atividade muscular e da liberação de catecolaminas no sangue. Além disso, a insensibilização gasosa é vantajosa sobre a elétrica em relação à incidência de salpicamento (Barton - Gade, 1997; Channon et al, 2002)

\subsubsection{Abate}

\subsubsection{Linha de processo e resfriamento}

A taxa de resfriamento influencia a qualidade da carne suína, já que ela depende do efeito do $\mathrm{pH} /$ temperatura do músculo (Bendall \& Swatland, 1988). Borchert et al. (1964) mostraram que o resfriamento com nitrogênio líquido previne a formação de carne PSE, e não encontraram diferenças nos valores de $\mathrm{pH}_{24 h}$. Mais tarde, Taylor et al. (1971) descobriram que o resfriamento acelerado com ar melhorou a CRA, sendo este fato confirmado por outros autores (Bertram et al., 2001). Entretanto, outros estudos não apresentaram nenhum efeito do resfriamento acelerado ou retardado na CRA (Gigiel et al., 1989; Jones et al., 1993) embora Jones (1993) tenha observado melhora na cor.

Um problema que pode surgir com o resfriamento acelerado é o encurtamento pelo frio, que pode ocorrer se a temperatura diminuir muito rapidamente, isto é, enquanto o nível de energia nos músculos ainda estiver 
alto (Locker et al., 1963). Honikel et al. (1986) encontraram ser o comprimento do sarcômero positivamente relacionado com a CRA. De fato, a carne resfriada rapidamente apresentou-se mais dura que a carne resfriada convencionalmente (Jones et al., 1993), fato, este, indicativo de encurtamento pelo frio. Assim, este encurtamento pelo frio e seus efeitos negativos na CRA podem, sob condições específicas, contrabalançar os efeitos benéficos do resfriamento rápido na desnaturação protéica.

$O$ efeito do resfriamento na CRA pode também ser explicado por um efeito direto da temperatura no metabolismo energético post mortem ou por um efeito induzido pela temperatura na mobilidade e na distribuição de água nos músculos, ou por uma combinação dos dois fatores. Bertram et al. (2001) mostraram que a CRA apresentou melhora na carne resfriada em túnel de resfriamento comparado com carne resfriada através de banho de resfriamento comercial.

$\mathrm{O}$ processo de abate pode afetar a velocidade de redução do $\mathrm{pH}$. Inicialmente, deve ser assegurado que o processo de insensibilização seja eficiente e leve o animal à inconsciência imediata. A remoção mais rápida do calor das carcaças resulta numa rápida redução da temperatura e, conseqüentemente, minimiza a queda do $\mathrm{pH}$. O calor pode ser removido mais rápido, reduzindo-se o tempo entre a insensibilização e a sangria e entre a insensibilização e o resfriamento, melhorando, com isso, a eficiência do sistema de resfriamento. Recomenda-se que as carcaças atinjam a câmara de resfriamento dentro de 45 minutos post mortem, sendo 30 minutos considerado o tempo ideal.

\subsubsection{Estimulação elétrica}

O resfriamento acelerado pode causar o encurtamento pelo frio no músculo, com efeitos prejudiciais na maciez da carne e na CRA. A estimulação elétrica da carcaça bovina e de cordeiro é muito usada para prevenir o 
encurtamento pelo frio, já que a estimulação elétrica acelera o metabolismo post mortem no músculo, com efeitos benéficos na maciez (Pearson et al., 1985).

Em suínos, a estimulação elétrica também melhora a maciez da carne (Bowker et al., 1999; Taylor et al., 1995). Entretanto, Hallund e Bendall (1965) relataram que a estimulação elétrica acelerou a taxa de declínio do $\mathrm{pH}$ em suínos, resultando num aumento da freqüência de carne PSE. Essas observações foram posteriormente confirmadas (Bowker et al., 1999; Warriss et al., 1995). Por outro lado, a estimulação elétrica 20 minutos post mortem combinada com o resfriamento acelerado mostrou não reduzir a CRA utilizando alta (Taylor et al., 1992) ou baixa (Taylor et al., 1995) voltagem na estimulação. Portanto, se a estimulação elétrica for aplicada depois de 20 minutos post mortem, ela não afeta a CRA negativamente (Rosenvold et al., 2003).

\subsubsection{Suspensão pélvica}

A suspensão pélvica das carcaças logo após o abate e anterior ao início do rigor resultou no alongamento de diversos músculos do quadril comparado com a suspensão convencional pelo tendão de Aquiles (Rosenvold et al., 2003). A suspensão pélvica foi introduzida inicialmente para carcaças bovinas e de cordeiro, a mais de 30 anos atrás (Fischer et al., 2000) e tem sido sugerida como uma alternativa para a estimulação elétrica, quando o resfriamento acelerado é utilizado. Tem sido relatado que a suspensão pélvica das carcaças suínas, devido ao alongamento dos músculos, apresentou maior comprimento de sarcômero e maior maciez (Taylor et al., 1995) melhorando também a CRA (Dransfield et al., 1991). A redução da perda por exsudação é também, provavelmente, devido ao maior comprimento do sarcômero nos músculos alongados (Honikel et al., 1986). Além disso, os rendimentos de processamento (absorção da salmoura e retenção) foram maiores depois da suspensão pélvica (Fisher et al., 2000). 


\subsection{Fatores que favorecem o desenvolvimento das condições PSE e DFD}

Uma carne pálida, flácida e exsudativa (PSE) representa o principal problema de qualidade na indústria da carne suína. Devido à baixa capacidade de retenção de água, textura flácida, cor pálida e às elevadas perdas de água durante o processamento, a carne PSE é indesejável tanto para os consumidores como para a indústria de processamento (Bowker et a, 1999).

A principal causa do desenvolvimento da condição PSE é uma decomposição acelerada do glicogênio antes e após o abate (Figura 4). O aumento na concentração de ácido lático que acompanha esse processo resulta num decréscimo rápido no valor do $\mathrm{pH}$ do tecido muscular. Devido à temperatura do músculo estar próxima do estado fisiológico $\left(>38^{\circ} \mathrm{C}\right)$, o decréscimo do $\mathrm{pH}$ é seguido por um processo de desnaturação protéica, favorecendo o estabelecimento da condição PSE (Honikel \& Kim, 1986). As combinações críticas entre $\mathrm{pH}$ e temperatura estão ilustradas na Figura 5 (Gregory, 1998). 


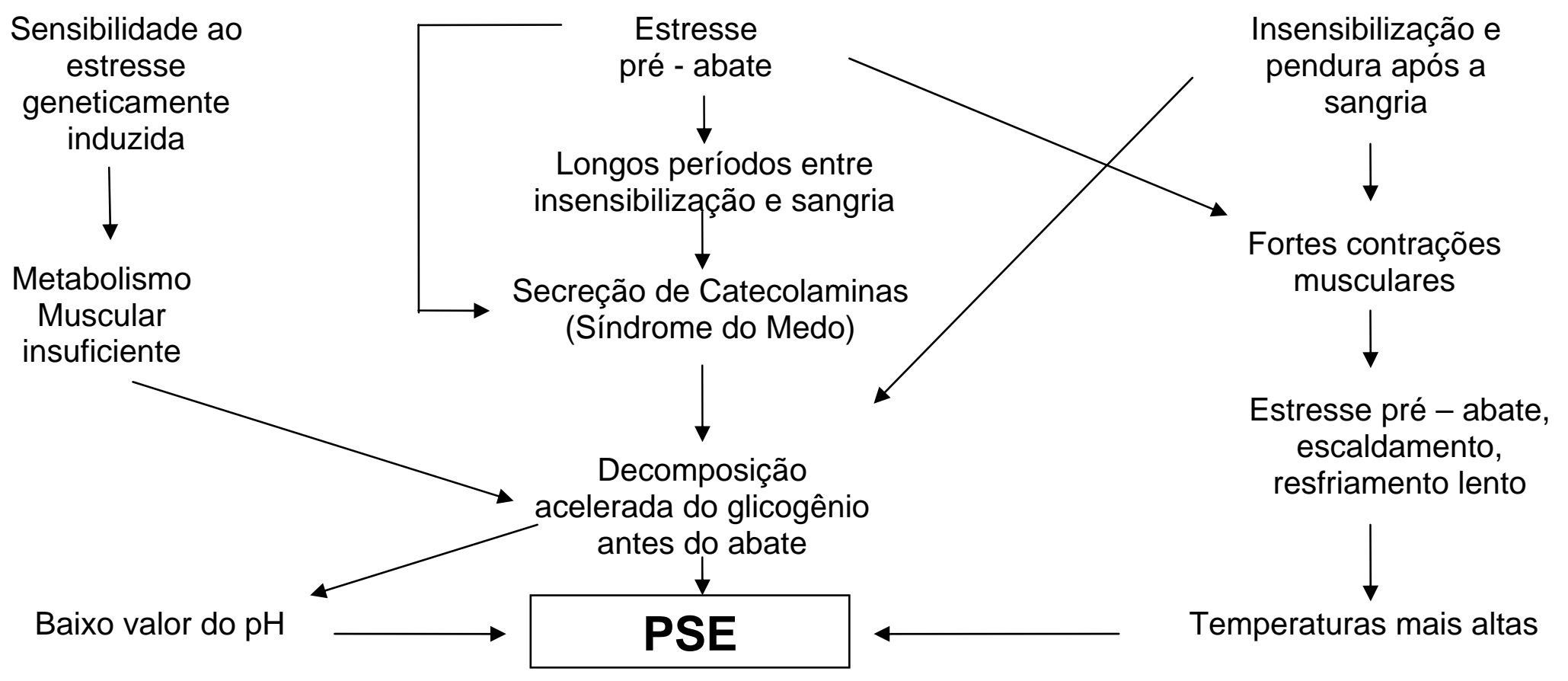

Figura 4. Fatores que favorecem o desenvolvimento da condição PSE 


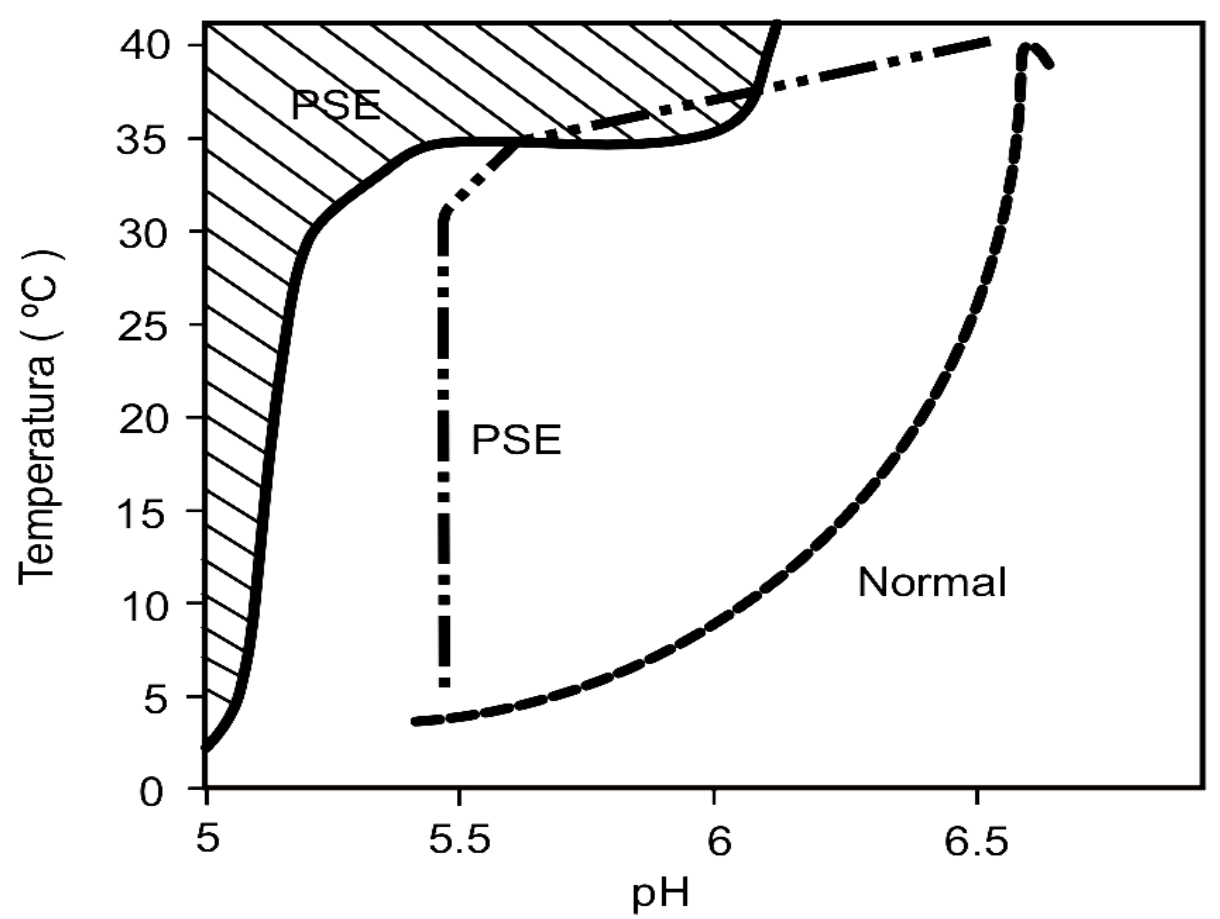

Figura 5 - Relação entre pH e temperatura em carne normal e PSE. (Se um músculo encontrar-se na área hachurada durante seu metabolismo post mortem, desenvolverá carcacterísticas PSE)

A glicólise acelerada é uma ocorrência multifatorial, incluindo influências endógenas e exógenas (Augustini, 1982; Lengerken et al., 1980). O fator mais importante é, sem dúvida, o metabolismo energético insuficiente de certas linhas genéticas que apresentam maior susceptibilidade ao estresse. Em condições de estresse, através de um processo de anaerobiose, carboidratos são decompostos objetivando a geração de energia (síntese de ATP). Como resultado, é formada uma pequena quantidade de ATP, alta concentração de ácido lático e um aumento na produção de calor. Estes processos são promovidos pelo efeito estimulante das catecolaminas (adrenalina, noradrenalina), que são liberadas no início de uma determinada reação de estresse e, através de uma longa reação em cadeia, ativa o primeiro passo na decomposição do glicogênio (separação e fosforilação das unidades de glicose). 
Os movimentos musculares envolvem sempre o consumo de ATP e, particularmente no caso de contrações mais intensas, a reposição dessa energia é efetuada pela glicólise (processos metabólicos anaeróbios). Além dos fatores exógenos que promovem a decomposição do glicogênio, existem outras influências responsáveis pelo aumento da temperatura corporal ou da temperatura da carne que resultam na condição PSE. Ressalta-se, novamente, a importância do estresse psicológico e térmico antes do abate.

No caso da carne apresentar a anomalia DFD, a falta de glicogênio já se faz presente na respectiva musculatura antes do abate. As razões são quase que exclusivamente de natureza exógenas (fortes contrações musculares e jejum prolongado) e, por esse motivo, a condição DFD pode ser prevenida eficientemente pelo manejo pré-abate adequado (Fischer, 1987).

Na prática, diversas situações podem levar a carne DFD. Em um estudo onde foram avaliadas condições de transporte, foi relatado que $18 \%$ dos suínos transportados num caminhão com piso escorregadio, sem divisões e sem qualquer mecanismo de ventilação apresentaram a anomalia DFD no músculo do quadríceps femural. Por outro lado, somente 10\% dos suínos foram DFD após o transporte num veículo adequado, com piso não escorregadio, divisões e mecanismo de ventilação (Nielsen, 1977). Além do fator transporte, os suínos, ao brigarem nas pocilgas de espera do abatedouro, usam seu glicogênio muscular, podendo levar à exaustão e à carne DFD. O grau de depleção do glicogênio é controlado por três processos:

- glicogenólise, o qual é ativado pela adrenalina da medula adrenal;

- utilização de ATP, o qual ocorre durante exercícios (a glicogenólise poderia ser usada como uma resposta secundária para ajudar a repor o ATP);

- ressíntese do glicogênio durante os períodos de repouso após as lutas.

A extensão da depleção do glicogênio também varia entre os músculos. Quando os suínos brigam, os músculos do pescoço e da paleta são usados para dar cabeçadas e bater no oponente. Dessa forma, estes músculos estão particularmente mais predispostos a se tornarem esgotados. O músculo 
Longissimus dorsi, por outro lado, é menos ativo, ocorrendo uma limitada depleção de glicogênio (Fernandez et al., 1995). Em alguns músculos do pernil pode haver depleção de glicogênio, mas seria incomum observar DFD no Semitendinosus. Dentro de um músculo, a depleção de glicogênio tende a ocorrer primeiro nas fibras de contração rápida; quando há o esgotamento destas, são as fibras de contração lenta que perdem seu glicogênio.

Em resumo, as condições que podem levar à depleção do glicogênio muscular e à carne DFD são:

- brigas entre os animais;

- dificuldade em manter o equilíbrio durante o transporte;

- jejum combinado com exercício;

- longas distâncias e elevado tempo de transporte;

- falta de familiaridade no manejo dos animais;

- insufuciente tempo de descanso nas pocilgas dos abatedouros.

A reposição do glicogênio depende da disponibilidade de substrato na corrente sangüínea. Quando disponíveis, o glicogênio muscular pode ser reposto rapidamente.

\subsection{Redução do pH da carne suína e suas relações com a qualidade}

O metabolismo da reserva de energia intramuscular (glicogênio) desempenha o papel principal na conversão de músculo em carne e na expressão dos diferentes atributos da qualidade da carne suína. Existe uma grande chance de incidência de carne PSE (Figura 6) quando o ácido lático intramuscular acumula-se rapidamente (menos de uma hora pós-sangria), reduzindo o pH abaixo de 6 enquanto a temperatura da carcaça está próxima do seu estado fisiológico $\left(>38^{\circ} \mathrm{C}\right)$, conforme ilustrado por Gregory, (1998). Fatores que afetam a glicólise post mortem (metabolismo post mortem do glicogênio) podem ser atribuídos a vários eventos: 1) predisposição genética (Síndrome de Estresse Porcino); 2) metabolismo elevado ou tendência do suíno 
apresentar alta excitabilidade; 3) estresse pré-abate; 4) combinações das condições anteriores. A velocidade de queda do $\mathrm{pH}$ é aproximadamente três vezes mais rápida nas carcaças que apresentam a anomalia PSE. Esta redução rápida do $\mathrm{pH}$, enquanto a temperatura da carcaça está acima de $38^{\circ} \mathrm{C}$, leva à desnaturação das proteínas musculares que ligam a água, resultando numa carne flácida e exsudativa. Se a redução do pH continuar, atingirá um ponto onde a carga líquida associada às principais proteínas contráteis é igual a zero. Neste ponto (ponto isoelétrico), o músculo possui baixa afinidade com a água. Como $75 \%$ da carne suína é destinada ao processamento, torna-se economicamente inviável a industrialização de carne que apresente baixa CRA.

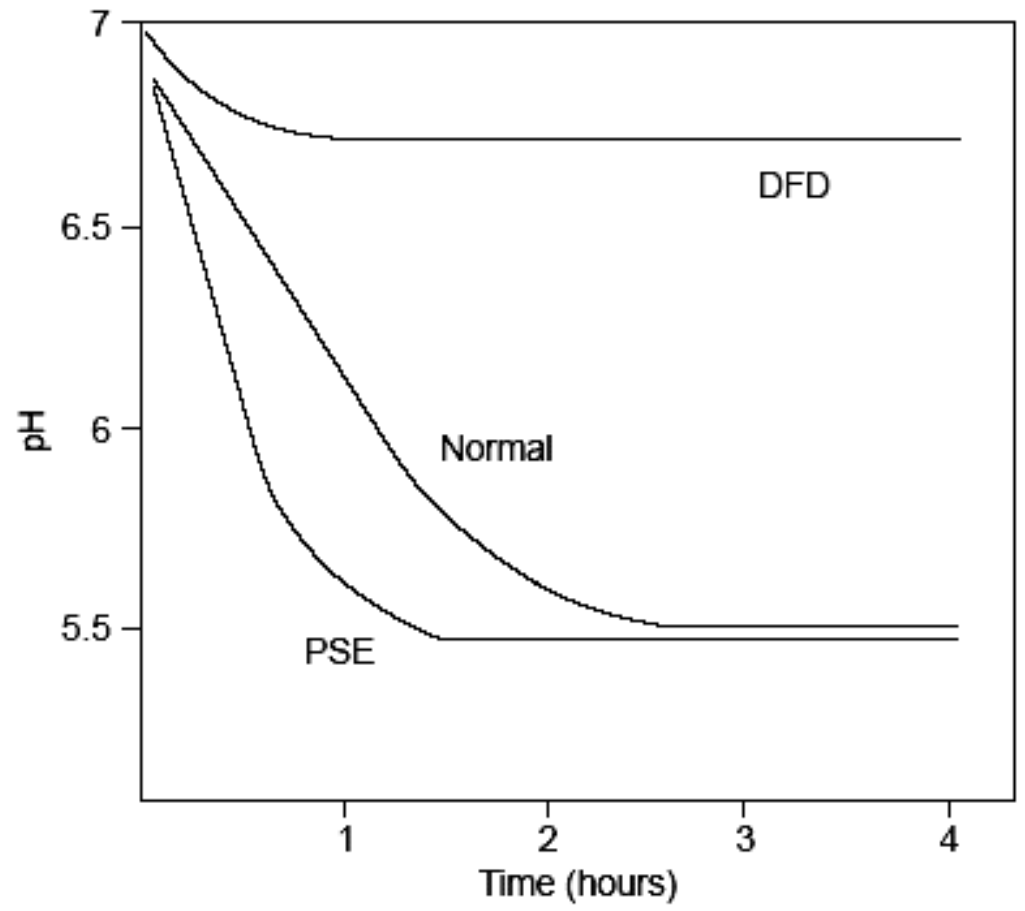

Figura 6 - Queda do pH em músculos destinados a tornarem-se PSE, DFD ou normais

Embora o pH não seja realmente uma medida de qualidade de carne per si, sua associação com outras características de qualidade tais como cor, capacidade de retenção de água, suculência e maciez da carne é muito forte. 


\subsubsection{Como o pH afeta a cor da carne}

A cor é um dos atributos mais importantes de qualidade de carne, uma vez que influencia a atratividade da compra de carne fresca pelos consumidores (Joo et al., 1995). Ela é determinada pela proporção relativa das três formas da mioglobina (heme pigmento): mioglobina reduzida $(\mathrm{Mb})$, de coloração vermelho púrpura; mioglobina oxigenada ou oximioglobina $\left(\mathrm{O}_{2} \mathrm{Mb}\right)$, de coloração vermelho brilhante e mioglobina oxidada ou metamioglobina (MetMb), de coloração marrom (Sarantópoulos, 1990).

Quando o animal é submetido a "stress" antes do abate, ocorre uma redução do teor de glicogênio muscular. Isso resulta num $\mathrm{pH}$ elevado, o que torna mais ativa a citocromoxidase das mitocôndrias. Assim, um aumento no consumo de oxigênio pelas mitocôndrias ocorre preferencialmente à oxigenação da mioglobina, aumentando, dessa forma, a concentração de mioglobina desoxigenada, resultando em carnes de cor escura. Em carnes normais, a glicólise post mortem reduz o pH a 5,8 ou menos, o que diminui o consumo de oxigênio pelas mitocôndrias, permitindo o "bloom" normal na superfície da carne exposta ao ar (Sarantópoulos, 1990).

Ledward (1971) verificou que o quando ocorre uma desidratação da superfície da carne, seu escurecimento não decorre do aumento na formação de MetMb, mas, provavelmente, advém da concentração dos pigmentos na sua superfície.

Quando a redução do $\mathrm{pH}$ post mortem é muito rápida e a temperatura da carcaça ainda é alta, ocorre uma desnaturação parcial das proteínas sarcoplasmáticas (proteínas do citoplasma das células musculares) e miofibrilares, ocasionando uma diminuição da capacidade de retenção de água da carne. Ocorre, desta maneira, um aumento na dispersão da luz, resultando em carne com aparência pálida.

De acordo com Offer \& Knight (1988), a modificação do pH de uma suspensão do miofibrilas resulta numa mudança no volume dessas proteínas, 
podendo afetar seu poder de dispersão da luz. A dispersão da luz é máxima quando o $\mathrm{pH}_{24}$ for 5,0, onde o volume miofibrilar é mínimo e o índice de refração das bandas $\mathrm{A}$ e I e as diferenças entre eles é máxima. A dispersão da luz diminui em valores de $\mathrm{pH}_{24}$ maiores ou menores que 5,0.

\subsubsection{Como o pH afeta a maciez da carne}

As condições que afetam a integridade estrutural do músculo post mortem afetarão também as características de qualidade da carne. Actina e miosina são as principais proteínas contráteis associadas com a formação da rede protéica da carne. A miosina liga-se à actina durante a contração muscular e forma uma ligação permanente na carne. O grau de desnaturação da miosina, como resultado do baixo $\mathrm{pH}$, afetará a perda por exsudação e a maciez da carne, associadas com a condição PSE.

\subsubsection{Como o pH afeta a capacidade de retenção de água}

Tem sido reportado que a CRA da carne suína é influenciada por vários fatores, incluindo o último $\mathrm{pH}$, a desnaturação protéica, os espaços inter e intrafasciculares e o comprimento do sarcômero (Offer \& Knight, 1988). Tem sido sugerido ser a desnaturação da miosina a causa da alta taxa de perda por exsudação na carne suína PSE (Offer, 1991). A carga elétrica líquida da miosina torna-se mínima assim que o pH aproxima-se de 5,1, resultando numa baixa capacidade de retenção de água. A habilidade de a carne suína reter água é afetada pelo arranjo espacial das proteínas musculares. Portanto, o grau de desnaturação protéica tem um efeito na habilidade do músculo em reter umidade. Alguns autores afirmaram que a rápida queda do $\mathrm{pH}$ em temperaturas musculares próximas ao estado fisiológico $\left(38^{\circ} \mathrm{C}\right)$ leva a desnaturação da miosina, resultado no encurtamento da cabeça da miosina, juntando os filamentos grossos e finos. Este encurtamento, adicionado ao encurtamento dos 
miofilamentos devido ao baixo $\mathrm{pH}$ final na carne suína PSE, resulta numa maior quantidade de fluído sendo expelido entre as fibras e os feixes de fibras (Offer \& Knight, 1988; Irving et al., (1989). Offer (1991) relatou que o encurtamento da cabeça de miosina e a perda da atividade catalítica da miosina são eventos decisivos na determinação da PE do músculo suíno. Entretanto, esses eventos podem ter uma dependência diferente no $\mathrm{pH}$ e na temperatura no período de post mortem imediato.

A qualidade da carne suína que é aceitável na cor, mas apresenta uma exsudação excessiva corresponde à carne RSE (vermelha, flácida e exsudativa), conforme descrito por Kauffman et al. (1992), Warner et al. (1993) e Van Laack et al. (1996).

A obtenção do pH 45 minutos post mortem (pH45) é um excelente critério para avaliar a velocidade da glicólise post mortem e, assim, estimar a qualidade da carne (Silveira, 1997).

\subsection{Composição da carcaça e quantidade de carne suína}

A composição da carcaça refere-se à quantidade proporcional de carne ou músculo presente na mesma. Os diferentes graus de musculatura e de gordura (refletindo as variações na proporção osso/músculo) são os fatores primários associados à composição da carcaça. Idealmente, esta composição deve contemplar maior proporção de músculo, enquanto que gordura, ossos e pele são mantidos em menores proporções, porém, sem prejudicar a qualidade da carne e os fatores de produção animal.

A quantidade de gordura dos suínos pode se elevar dependendo do corte cárneo ou da forma pela qual a carne é processada. Cerca de $70 \%$ desta

gordura não está na carne, mas encontra-se abaixo da pele (toucinho). Apenas 20 a $22 \%$ de gordura estão entre os músculos ou dentro deles, contribuindo com o sabor e a maciez da carne. Tratando-se especificamente da gordura intramuscular, se a carne for bem manipulada, retirando-se todas as aparas que 
envolvem o músculo, seu teor de gordura será semelhante ao da carne de frango (1,1 a 2,4\%) (Roppa, 1999).

Quanto às modificações na composição lipídica da carne suína, deve-se levar em consideração o conteúdo de gordura intramuscular, pois uma redução da mesma para níveis menores que $2 \%$ compromete o sabor, o aroma e a suculência, características essas consideradas favoráveis do ponto de vista sensorial (Cameron et al., 2000).

Buege et al. (1997) mostraram que de 1989 a 1996, os suínos apresentaram uma redução de 2,3 para $1,4 \mathrm{~mm}$ na camada de gordura que reveste todos os cortes cárneos; o rendimento de carne magra dos cortes aumentou de 75 para 81\%; a quantidade de gordura contida nos cortes magros caiu de 5,2 para $4,8 \%$ e a quantidade de lipídios insaturados permaneceu a mesma (58\%).

\subsection{Fatores que afetam a composição e a quantidade da carne suína}

\subsubsection{Genótipo / raça}

A quantidade de carne nas carcaças de genótipos modernos está intimamente relacionada com a qualidade da carne. A raça Pietran é conhecida por apresentar uma carne extremamente magra, mas pobre em qualidade. Os machos Pietrain são usados no cruzamento terminal com o objetivo de se aumentar o nível de deposição de carne nos suínos de engorda. Isto pode, infelizmente, resultar numa diminuição da qualidade de carne. Em estudo realizado por Sencic et al. (2002), foi comprovado que os cruzamentos com Pietrain foram caracterizados por apresentarem maior proporção de carne magra $(55,64 \%$ e $56,50 \%)$ comparado com Landrace alemão $(53,40 \%)$ como raça de terminação. Entretanto, os cruzamentos com Pietrain foram caracterizados pela deterioração da qualidade da carne, aumentando os valores de $\mathrm{pH}_{2 \mathrm{~h}}(5,86 ; 5,50 ; 5,50)$, PE $(8,50 ; 9,70 ; 9,80)$ e cor $(65,50 ; 58,00 ; 55,50)$, 
sendo que a carne desses animais apresentou maior conteúdo de proteína e menor conteúdo de gordura.

A raça Berkshire apresenta ótimas características de qualidade de carne. Esta raça possui finas fibras musculares e excelente CRA. Por outro lado, a raça Duroc é usada como série terminal quando são produzidos suínos de engorda; apresenta uma excelente taxa de crescimento e muita gordura intramuscular (Suzuki et al., 2003). Segundo Latorre (2003), as características de produtividade e de carcaça das linhas Duroc são similares ou até melhores que as características de linhas brancas (Landrace, Large White), sem qualquer perda de qualidade da carne. Suzuki et al. (2003) relataram que a raça Duroc apresentou maior AOL $(39,2$ × 31,4) e menor espessura de gordura $(1,8 \times 2,4)$ que a raça Brekshire, que obteve menores valores de PE $(4,08 \% \times 6,05 \%)$ e melhores valores de CRA que os animais Duroc.

Latorre et al. (2003) compararam animais das raças Duroc e Pietran e verificaram que os suínos de terminação Duroc cresceram mais rapidamente e apresentaram melhor conversão alimentar. Resultados similares foram encontrados por McGloughlin et al. (1998) e Fuler et al. (1995), que compararam Duroc com cruzamentos de Landrace ou de Large-White. Simpson et al. (1987) reportaram um maior crescimento e Edwards et al. (1992), maior quantidade de alimento ingerido em Duroc que em Large White. Entretanto, outros pesquisadores não encontraram diferenças na performance entre Duroc e Pietran (Ellis et al., 1996; Kanis et al., 1990) ou entre Duroc e Large White (Candek-Potokar et al., 1998).

\subsubsection{Genótipo / peso de abate}

Estudo realizado por Gu et al. (1992) avaliando a composição da carcaça de 5 genótipos de suínos castrados : 1- H x HD; 2- SYN; 3- HD x L(YD); 4- H x 
YD; 5- Y x L ( $\mathrm{H}=$ Hampshire, $\mathrm{D}=$ Duroc, SYN = Linha macho terminal sintético, $\mathrm{L}=$ Landrace e $\mathrm{Y}=$ Yorkshire) em quatro pesos de abate $(59,100,114,127 \mathrm{Kg}$ de peso vivo), puderam observar que a quantidade de carne, gordura, ossos e pele relativa à carcaça nos cortes primários não diferiram entre os genótipos. Os genótipos SYN e HD x L (YD) tinham quantidades similares de carne dissecada e excediam a média dos outros genótipos. As carcaças do L X YD continham maior espessura de toucinho nos dois últimos períodos de peso. Também foi observado que com o aumento de peso dos 5 genótipos, ocorria aumento na área de olho de lombo do músculo Longissimus dorsi . A média de carne $(\mathrm{kg})$ encontrada para os suínos no peso vivo de $100 \mathrm{Kg}$ variou de 33,41 (YxL) para 37,01 (HD x L(YD)).

Lan et al. (1993) analisaram carcaças de diferentes raças, Yorkshire (Y), Meishan (Ms), Fengjing $x$ Y, Minzhu x $Y, M s \times Y, e ~ Y \times$ Ms no peso de abate de $103 \mathrm{~kg}$. Os autores puderam observar que a espessura de gordura na 10a costela variava de 3,43 na raça $Y$ para $4,04 \mathrm{~cm}$ na raça $Y \times$ Ms. A área de olho de lombo $\left(\mathrm{cm}^{2}\right)$ variou de 16,90 na Ms para 28,84 na $Y$, e os cruzamentos obtiveram valores intermediários.

Moss et al. (1983) analisaram carcaças suínas com espessura de gordura dorsal de 2,3 a 2,5 cm quanto à composição física. O componente físico de cada corte variou muito. A média de carne foi de $52 \%$ no lombo assado para $70 \%$ na sobrepaleta. A porcentagem de gordura subcutânea era menor e a gordura intramuscular era maior na sobrepaleta.

Novakofski et al. (1989) também analisaram a composição de carcaças suínas comerciais, encontrando $2,6 \mathrm{~cm}$ de gordura na $10^{\mathrm{a}}$ costela e uma 34,2 $\mathrm{cm}^{2}$ para área de lombo. Valores semelhantes para a espessura de gordura e inferiores para área de olho de lombo foram encontrados por Devol et al. (1988) que reportaram uma média de espessura de gordura e área de olho de lombo de 2,68 cm e 29,96 $\mathrm{cm}^{2}$ respectivamente, para suínos castrados. 


\subsubsection{Nutrição / manejo / genótipo}

O uso de estratégias de manejo como a suplementação com ácido linolêico conjugado (ALC) na dieta e a administração intramuscular diária de somatotropina suína (STs) reduz, efetivamente, a espessura de gordura em suínos (D'Souza et al., 2002). Esses dados são consistentes com estudos prévios investigando a influência da suplementação de ALC na dieta (Cook et al., 1998; Dunshea et al., 1998; Thiel et al., 1998) e a administração diária de STs na espessura de gordura dos suínos.

A somatotropina recombinante suína (STrs), administrada intramuscularmente, melhora o ganho diário, a eficiência alimentar e a deposição de tecido magro nos suínos na fase de crescimento (Kanis et al., 1990). Como a STrs age através da modificação das taxas do processo metabólico, aumenta a deposição de proteína e diminui a deposição de gordura, resultando na redução das gorduras subcutânea e intramuscular, modificando, com isso, a composição da carcaça. Além disso, podem surgir efeitos adversos da STrs nos órgãos (aumento na deposição de proteína ou aumento no tamanho dos órgãos devido ao aumento das taxas metabólicas), na qualidade da carcaça e na qualidade de carne (a diminuição da gordura intramuscular diminui a aceitabilidade da carne, em termos sensoriais) (Nieuwhof et al., 1991 ; Dunshea, 1994).

Estudos realizados por Ender et al. (1992) e Lefaucher et al. (1992) apresentaram similares reduções dos níveis de gordura intramuscular em suínos submetidos à administração de STs. Entretanto, Carroll et al. (1999), Dugan et al. (1999) e Weigand et al. (2000) reportaram que a suplementação com ALC na dieta de suínos aumentou os níveis de gordura intramuscular. Por outro lado, D'Souza et al. (2002) não encontraram diferenças significativas nos níveis de gordura intramuscular entre os suínos submetidos ao tratamento controle, à administração de STs ou à suplementação com ALC. 
Cook et al. (1998), Dunshea et al. (1998), Thiel et al. (1998), relataram que a introdução do ALC na dieta e a administração de STrs melhoraram o $\mathrm{pH}_{24 h}$ e reduziram a superfície de exsudação, comparado com suínos submetidos ao manejo controle. Entretanto, esses resultados estão em contraste com estudos prévios (Dunshea \& Ostrowska, 1999; O'Quinn et al., 1998) que reportaram que a suplementação com ALC não apresentou efeito nos parâmetros de qualidade de carne, como a luminosidade, $\mathrm{pH}_{24 h}$, perda por exsudação ou perda por cozimento. Similarmente, estudos prévios realizados por Ender et al. (1992) e Lefaucheur et al. (1992) reportaram que a administração de STs não influenciou significativamente a qualidade da carne suína.

Wiegand et al. (2001) investigaram a eficiência da suplementação com ácido linolêico conjugado (ALC) a $0,75 \%$ do total da dieta de suínos de genótipos carregadores do gene Halotano (Nn), homozigóticos negativos (NN) e homozigóticos positivos (nn). Os animais que receberam a dieta com ALC tiveram uma melhor conversão alimentar $(350 \mathrm{~g} / \mathrm{Kg}$ alimento) que os animais que receberam a dieta controle $(330 \mathrm{~g} / \mathrm{Kg}$ de alimento), independente do genótipo. Os autores relataram que os animais que receberam a suplementação com ALC exibiram menor profundidade de toucinho na $10^{\mathrm{a}}$ $(2,34 \mathrm{~cm} \times 2,84 \mathrm{~cm})$ e na última costela $(2,46 \mathrm{~cm} \times 2,72 \mathrm{~cm})$ que os suínos submetidos à dieta controle. $O$ estudo mostrou que a $A O L$ não foi afetada pela suplementação com ALC. Com relação aos genótipos, as carcaças positivas tiveram maior $\mathrm{AOL}\left(45,02 \mathrm{~cm}^{2}\right)$ e as carcaças negativas, menor $\left(40,76 \mathrm{~cm}^{2}\right)$. A pontuação subjetiva para cor não foi afetada pelo ALC, mas a cor foi diferente entre os genótipos, com pontuações de 1,50,2,40 e 3,10 para genótipos positivo, carregador e negativo, respectivamente. De acordo com Wiegand et al. (2001), o marmoreio aumentou em todos os genótipos com a suplementação.

Dunshea et al. (2002) conduziram dois estudos para avaliar o efeito do ALC sob condições comerciais utilizando suínos modernos. Os autores reportaram que a carne de suínos tratados com ALC tendeu a ser mais escura 
e com maior $\mathrm{pH} 24 \mathrm{~h}$. Desta forma, os dados sugerem que sob condições comerciais, a suplementação com ALC pode melhorar a performance de crescimento e diminuir a espessura de gordura em suínos com genótipo melhorado, particularmente as fêmeas.

Berg et al. (2003) avaliaram a relação entre concentrações séricas do hormônio leptina com o crescimento e as características de carcaça em 6 diferentes raças suínas (Berkshire, Chester White, Duroc, Landrace, Poland China e Yorkshire .Concluíram que existiram diferenças entre as raças de uma maneira coerente com as características específicas das raças para crescimento, quantidade de carne magra e qualidade. Desta forma, a leptina pode servir como um marcador útil para a seleção ou a identificação de características específicas de crescimento e de carcaça.

Chiba et al. (2002) investigaram o efeito da utilização de dietas de restrição durante a fase de crescimento em genótipo selecionado para eficiência na deposição de carne magra. Segundo os autores, não houve efeito do genótipo na performance de crescimento, mas o genótipo selecionado apresentou melhor qualidade de carcaça e a utilização de aminoácidos para o crescimento foi mais eficiente que os animais do controle. De acordo com Chiba et al. (2002), durante a fase de crescimento, os suínos que receberam maior quantidade de aminoácidos na dieta de crescimento cresceram mais rápido e apresentaram menor espessura de gordura que os animais submetidos à dieta com baixo teor de aminoácidos. Os autores relataram também que embora tenham sido observadas algumas interações entre as dietas de crescimento e de terminação, não houve indicações de que os animais submetidos a uma restrição mais precoce de aminoácidos tivessem exibido um ganho de peso compensatório, ou tivessem diferentes requerimentos de aminoácidos na fase seguinte. A taxa de acréscimo de carne magra foi similar entre os suínos alimentados com dietas de crescimento com alto ou baixo conteúdo de aminoácidos independente do genótipo, indicando que o crescimento de tecido magro compensatório pode ocorrer em suínos submetidos a restrições 
precoces de aminoácidos. Além disso, os autores relataram que os suínos submetidos à restrição tiveram uma melhor eficiência alimentar na fase seguinte, o que pode ter um impacto positivo no meio ambiente devido à redução da excreção de nutrientes inutilizados. Os suínos selecionados, alimentados com uma dieta de crescimento contendo baixo teor de aminoácidos tiveram menor ganho de peso comparado com os outros grupos. Desta forma, os resultados apresentados pelos por Chiba et al. (2002) dão a entender que os suínos selecionados para eficiência na deposição de carne magra podem ser menos tolerantes à restrição precoce de aminoácidos e que fornecer uma dieta de crescimento contendo quantidades adequadas de aminoácidos pode ser importante para otimizar a performance de crescimento.

\subsubsection{Sistemas de produção I manejo / genótipo / sexo}

Embora pouco difundida nas condições brasileiras, a criação de suínos com separação de sexo deve ser vista como estratégica, considerando as diferenças de exigências nutricionais a que Ihes são atribuídas. Sabe-se que as respostas para desempenho e qualidade de carcaça diferem entre machos castrados e fêmeas, como decorrência das variações dos níveis nutricionais exigidos (Ekstrom, 1991). De acordo com o autor, machos castrados consomem mais alimentos e têm maior ganho de peso. Ao mesmo tempo, as fêmeas ingerem menos alimentos e são mais eficientes na deposição de carne na carcaça (comparadas a machos castrados), embora as exigências em aminoácidos possam ser maiores. Experimento realizado por Cromwell et al. (1993) mostrou que os machos castrados consumiam mais dieta e produziam carcaças com maior teor de gordura e menos músculo do que as fêmeas. Aumentando o nível de proteína na dieta, ocorria na fêmea, aumento da

gordura dorsal na carcaça, área de olho de lombo e musculosidade, porém no macho castrado o aumento protéico na dieta tinha pouco efeito. Os autores 
encontraram para espessura de gordura na $10^{\mathrm{a}}$ costela a média de $3,11-3,38$ para machos castrados e 2,67-2,91 para fêmeas, e para área de olho de lombo $\left(\mathrm{cm}^{2}\right)$ valores de $29,1-32,6$ e 30,5-36,3, para machos e fêmeas, respectivamente com adição de lisina na dieta de 12 para 16\%. A porcentagem de carne encontrada foi de $51,3-53,1 \%$ para os machos castrados e $53,9-56,1 \%$ para as fêmeas.

Dentro dos genótipos, diferenças no sexo resultam em alterações no desempenho do crescimento, acréscimo de proteína e requerimentos de lisina. Stahly et al. (1991) sugeriram que machos e fêmeas requerem maior ingestão de lisina para facilitar o aumento no acréscimo de proteína. Além disto, fêmeas possuem decréscimo na ingestão da dieta, necessitando de uma maior quantidade de lisina / $\mathrm{kg}$ de dieta para otimizar o acréscimo de proteína. A seleção para redução da espessura da gordura e aumento da utilização do alimento tem resultado em suínos com aumento no ganho potencial. Os genótipos caracterizados como tendo um alto potencial para ganho de tecido muscular têm resultado em uma melhor performance e crescimento comparado com genótipos com médio potencial para ganho de peso (Friesen et al., 1994).

D'Souza et al. (2002) estudaram a influência do genótipo, sexo e estratégias de manejo na qualidade da carne de suínos de genótipos A (50\% Duroc) e B (<25\% Duroc). Constataram que os animais do genótipo A obtiveram menor espessura de gordura, maior porcentagem de gordura intramuscular, maior $\mathrm{pH}_{24 \mathrm{~h}}$ e perda por exsudação, além de apresentarem uma carne mais dura e com menor aceitabilidade comparada com o genótipo B. D'Souza relataram que, com relação ao sexo, as fêmeas tiveram menor $\mathrm{pH}_{24 \mathrm{~h}}$, maior perda por exsudação e carne mais dura comparadas com os machos. Com relação às estratégias de manejo, os animais submetidos à dieta controle apresentaram menor $\mathrm{pH}_{24 \mathrm{~h}}$ e maior perda por exsudação comparado com os animais cuja dieta foi suplementada com ALC ou que receberam somatrotofina suína. Além disso, o estudo mostrou que os animais submetidos à dieta 
controle obtiveram maior aceitação do consumidor em relação aos atributos sensoriais de suculência, sabor e maciez. Desta forma, os autores concluíram que as características de qualidade da carne suína dependem de uma complexa interação entre genótipo e sexo. Concluíram também que as estratégias de manejo, como a administração de STs e a suplementação com ALC, enquanto mostram-se efetivas na redução da espessura de gordura, podem gerar um impacto negativo na qualidade da carne suína.

\subsubsection{Peso de abate / sexo}

No passado, os atributos de qualidade de carne eram geralmente considerados independentes do peso do animal vivo ou do peso da carcaça (Sather et al., 1991). Obviamente, o aumento do peso da carcaça aumenta, concomitantemente, a idade de abate. É difícil obter suínos de diferentes pesos com a mesma idade de abate e vice-versa, sem alterações no genótipo ou na alimentação. Esses fatores, entretanto, possuem uma grande influência nos parâmetros que afetam a qualidade de carne, como a concentração de colágeno no músculo (Touraille et al., 1989) e o conteúdo de gordura intramuscular (Wood et al., 1990). Martin et al. (1980) e Unruh et al. (1996) mostraram significantes transformações na cor da carne com o aumento do peso da carcaça, enquanto Shuler et al. (1970) e Sutton et al. (1997) relataram não haver relação entre cor de carne e peso de carcaça.

O aumento do peso de carcaça é uma maneira de aumentar o volume e a eficiência do processo de produção de suínos, onde os custos por unidade de peso são significativamente reduzidos (Beattie et al., 1999). Além disso, o aumento da oferta de $\mathrm{Kg}$ de suínos ou carcaças, e não do número de animais vivos, é importante, pois contribui para estabilização do preço numa faixa satisfatória para o produtor, evitando um aumento desenfreado e reduzindo o risco de importação pelas indústrias. Porém, existem algumas dificuldades na criação de suínos mais pesados. Para Roppa (2004), a principal delas é a piora 
da conversão alimentar, o que representa aumento no custo de produção. Isto se deve ao aumento na produção de gordura proporcionalmente à produção de carne na carcaça exigindo maior quantidade de ração por $\mathrm{Kg}$ de suíno produzido. Este aumento de deposição de gordura implica em menor rendimento de carcaça, e em abatedouros com tipificação de carcaça há queda no pagamento de bonificações. Além disso, maior peso de abate requer mais tempo de permanência dos animais nas instalações, e conseqüentemente, mais área de criação e aumento nos custos de mão de obra. Roppa (2004) sugere o uso de restrição alimentar, iniciada na fase final da recria, para se melhorar a conversão alimentar dos suínos mais pesados. Reconhece, porém, que não é tão simples assim fazer restrição alimentar, face à diversidade de rações e genéticas disponíveis no mercado, dificultando estabelecer um manejo alimentar específico para a criação de suínos mais pesados.

Candek-Potokar (1998) avaliou o efeito da dieta e/ou peso de abate (100 e $130 \mathrm{Kg}$ ) sobre o músculo Longissimus dorsi com alimentação ad libitum (A) e restrita (R). Os autores puderam observar que com a restrição de alimentação e com o aumento da idade nos dois pesos de abate, resultava em melhor eficiência alimentar e ganho de carne magra. A gordura intramuscular era reduzida pela restrição de dieta. Aumento em ambos parâmetros de idade e peso de abate dos suínos resultava em menor teor de umidade, maior concentração de proteína e maior conteúdo de gordura intramuscular (IMF).

De acordo com Beattie et al. (1999), o aumento no peso da carcaça aumenta o volume de carne magra por suíno por ano para a produção. Para Ellis \& Horsfield (1998), as mudanças nos perfis de demanda do consumidor têm também facilitado o uso de cortes suínos mais pesados. A desvantagem dessa tendência é que os consumidores exigem carne mais magra, mas, tradicionalmente, o aumento no peso da carcaça foi associado com um aumento da quantidade de gordura. Entretanto, para Bettie et al. (1999), a intensa seleção genética para uma maior deposição de carne magra vem alterando, dramaticamente, a composição da carcaça suína, desde a década de 
50, diminuindo a taxa de gordura: carne que passou de 0,87 na década de 60 (Adam \& Smith, 1966) para 0,24 na década de 90 (Beattie et al. 1999). Além disso, segundo os mesmos autores, os suínos modernos possuem maior quantidade de carne magra e o aumento no peso da carcaça exerce um menor impacto na composição da carcaça que nos seus antepassados.

Beattie et al. (1999) estudaram o efeito do aumento do peso de abate (92, 105, 118 e 131Kg) de machos e fêmeas de terminação na composição da carcaça e qualidade de carne. Relataram que com o aumento do peso da carcaça, houve um aumento significante na $\mathrm{AOL}\left(36,9 ; 42,6 ; 44,5 ; 45,6 \mathrm{~cm}^{2}\right)$ e no conteúdo de gordura subcutânea $\left(117 ; 132 ; 161 ; 169 \mathrm{~g} . \mathrm{Kg}^{-1}\right)$. Por outro lado, o conteúdo de carne magra diminuiu com o aumento do peso da carcaça (654; $652 ; 625 ; 612 \mathrm{~g} \mathrm{Kg}^{-1}$ ), enquanto que o conteúdo de gordura intramuscular não foi afetado $\left(44 ; 40 ; 44 ; 44 \mathrm{~g} . \mathrm{Kg}^{-1}\right)$. Os mesmos autores encontraram uma interação significante entre peso da carcaça e sexo com porcentagem de perda por exsudação na carne das fêmeas suínas abatidas aos $131 \mathrm{Kg}$, que apresentaram valores maiores para esta característica que os machos $(6,26 \% \mathrm{x}$ $6,18 \%)$ e as fêmeas dos outros pesos de abate $(6,68 \% ; 6,08 \% ; 6,23 \% ; 5,88 \%$, para os respectivos pesos de abate, em ordem crescente). Os autores encontraram uma pequena, porém significante redução do $\mathrm{pH}_{24 \mathrm{~h}}$ com $\mathrm{O}$ aumento do peso de abate $(5,51 ; 5,51 ; 5,49 ; 5,48)$. Neste trabalho, a perda por cozimento também foi reduzida nos animais mais pesados (26,1\%; $25,2 \%$; $24,4 \% ; 23,5 \%$ ). Desta forma, Beattie et al. (1999) concluíram que a qualidade da carne pode ser melhorada quando se aumenta o peso de abate de 92 para $131 \mathrm{Kg}$.

Com relação à deposição de carne magra na carcaça, os machos são mais apropriados para o aumento de peso de abate. Beattie et al. (1999) relataram em seu estudo que as fêmeas, apesar de apresentarem maior deposição de carne magra, depositaram mais gordura que os machos. Similares diferenças entre os sexos foram reportadas em menores pesos de abate por McCracken et al. (1997). 
Candek-Potokar et al. (1998) encontraram valores de área de olho de lombo em suínos castrados de 34,7 e 44,1 cm² nos pesos de abate de 100 e $130 \mathrm{~kg}$, respectivamente. Os autores também avaliaram a espessura de gordura, observando valores de 27,3 a 34,2 mm, o que corrobora com o estudo realizado por Miller et al. (1990), que encontrou espessura de gordura na $10^{\mathrm{a}}$ costela de 29,9 mm, porém para a área de olho de lombo o valor encontrado foi inferior (29 $\mathrm{cm}^{2}$ ).

Os valores das avaliações das carcaças encontrados por Warnants et al. (1996) foram, para a porcentagem de carne magra, 56,3\% e 59,1\% para macho castrado e fêmea, respectivamente, e quanto à espessura de gordura do lombo, foi encontrado $22 \mathrm{~mm}$ para macho castrado e $17 \mathrm{~mm}$ para fêmea.

Wagner et al. (1999) reportaram para fêmea e macho castrado, no peso de abate de $100 \mathrm{~kg}, 2,52$ e 2,80 espessura de gordura $(\mathrm{cm})$ na $10^{\mathrm{a}}$ costela respectivamente, porém no peso de $84 \mathrm{~kg}$ a espessura de gordura $(\mathrm{cm})$ foi inferior tanto no macho $(2,49)$ quanto na fêmea $(1,99)$, sem diferença significativa entre os pesos. Os autores também avaliaram a área de olho de lombo $\left(\mathrm{cm}^{2}\right)$, encontrando no peso de $84 \mathrm{~kg}$ os valores de 29,93 e 31,49 para macho castrado e fêmea, respectivamente, e no peso de $100 \mathrm{~kg}$, os valores de 29,14 para macho castrado e 34,97 para fêmea. Beattie et al. (1999) encontraram valores para a área de olho de lombo ( $A O L)$ nas fêmeas superior ao macho castrado, e carcaças mais pesadas apresentaram maiores valores da AOL. Engeseth et al. (1992) também avaliaram o efeito da idade (2 a 6 semanas) na composição da carcaça em suínos. Pôde-se notar que a espessura de gordura $(\mathrm{mm})$ foi de 15,2 a 25,6, e a área de olho de lombo variou de 27,2 para 31,9 entre a $2^{\mathrm{a}}$ e $6^{\mathrm{a}}$ semana.

\subsubsection{Peso de abate I sexo I raça}


Gonzalez et al. (2001) investigaram o efeito do peso de abate, sexo e raça (Large White $x$ Landrace $x$ Pietrain e $(L W \times$ Landrace) $x$ LW) na composição carcaça suína. Constataram que os machos abatidos com pesos entre 25 - 105Kg tiveram valores significativamente maiores de ganho diário, quantidade de alimento ingerido e eficiência na conversão alimentar que as fêmeas do mesmo grupo de idade, enquanto que as fêmeas abatidas aos 105 $\mathrm{Kg}$ de peso vivo apresentaram menor espessura de gordura e maior porcentagem de carne magra que os machos. Nesse estudo, os autores verificaram que houve um aumento no conteúdo de proteína e de lipídio na carcaça com o aumento no peso do animal e que as carcaças de fêmeas e de cruzamentos Pietran tiveram menores níveis de lipídios e maiores níveis de proteína.

\subsubsection{Raça / gordura intramuscular}

O conteúdo de gordura intramuscular (GI) pode ser modificado por seleção do genótipo, pois a hereditariedade para o nível de gordura intramuscular varia entre 0,4-0,6. Correlações encontradas por Casteels et al. (1995) entre o nível de GI, o ganho de peso e espessura de gordura, indicou que é possível aumentar o nível de Gl por seleção de programas, sem conseqüências negativas para o crescimento e espessura da gordura dos animais.

Huff - Lonergan et al. (2002) encontraram uma correlação significante entre gordura intramuscular e espessura de gordura em suínos Berkshire $\mathrm{x}$ Yorkshire. Lonergan et. al. (2001) compararam uma linha Duroc tradicional com uma linha selecionada para eficiência na deposição de carne magra durante cinco gerações e encontraram que a porcentagem de gordura intramuscular foi maior na linha não melhorada. Latorre et al. (2003) observaram que a progênie de animais Duroc tiveram espessura de gordura similar (21,9 e 22,5), porém, mais gordura intramuscular $(3,4 \% \times 2,7 \%)$ que a progênie de Pietran $\times$ Large White. Além disso, o conteúdo de umidade foi menor na carne da progênie de 
Duroc que de Large White, o que está de acordo com Blanchard et al. (1999), que observaram uma diminuição da umidade e um aumento da gordura intramuscular quando a proporção de Duroc no produto final aumentou de 0 a $50 \%$ ás custas de Large White.

Tradicionalmente, um maior conteúdo de gordura intramuscular tem sido associado a uma maior suculência e a uma maior aceitabilidade da carne (Barton - Gade, 1987; Ellis et al., 1996). Entretanto, diversos autores não encontraram nenhuma vantagem na qualidade sensorial da carne suína com a inclusão de suínos Duroc (Edwards et al., 1992; McGloughlin et al., 1988). Blanchard et al. (1999) concluíram que pelo menos 50\% de Duroc foi requerida para uma aceitável melhora na qualidade sensorial da carne. Similarmente, em uma avaliação da raça Duroc (Meat \& Livestock Commission, 1992), foi encontrado que pelo menos $75 \%$ de inclusão de Duroc foi requerida para melhorar a qualidade da carne em termos sensoriais. 


\section{MATERIAL E MÉTODOS}

\subsection{Animais}

$\mathrm{Na}$ fase experimental do presente estudo, foram avaliados suínos, machos castrados e fêmeas, provenientes dos genótipos Excel (Pietrain $x$ Large White), Linha 21 (Pietrain puro), Maximus (L23 puro - linha sintética $=$ Pietrain $x$ Large White) e Optimus (macho híbrido Large White $x$ fêmea Linha $23=$ Pietrain $x$ Large White) do tipo híbrido comercial (Seghers Genetics do Brasil).

Segundo dados fornecidos pela empresa Seghers Genetics do Brasil, todos os genótipos foram selecionados para alto ganho de carne magra, sendo que a Linha 21 apresenta maior potencial para isto, seguida da Linha 23.

Com relação ao gene Halotano, os genótipos Máximus e Optimus são homozigotos dominantes ( $\mathrm{NN}_{\mathrm{M}}$ e $\mathrm{N} \mathrm{N}_{\mathrm{O}}$, respectivamente); o genótipo Excel é portador do gene ( $\mathrm{Nn})$ e o genótipo Linha 21 é homozigoto recessivo (nn). O gene $\mathrm{RN}^{-}$não é encontrado em nenhum genótipo.

\subsubsection{Dieta}

Os suínos receberam, durante seu crescimento e desenvolvimento, uma alimentação padrão composta por ração balanceada em nutrientes até os pesos aproximados de $95-100 \mathrm{~kg}$ (leve) e $115-120 \mathrm{~kg}$ (pesado). 
A composição da dieta recebida pelos animais do presente experimento, nas diversas fases do seu crescimento, encontra-se nas Tabelas 3 e 4.

Tabela 3. Composição das dietas oferecidas aos suínos na fase de 7 a 46 dias

\begin{tabular}{lcccc}
\hline INGREDIENTES $(\mathrm{kg})$ & R.SU.PR1 & R.SU.PR2 & R.SU.PR2 & R SU.IN1 \\
\hline Multimaternidade 600 & 300,0 & --- & --- & -- \\
Multimaternidade 400 com ADO & --- & 200,0 & 200,0 & --- \\
Multicreche & --- & --- & --- & 125,0 \\
Multidesmame & --- & 2,5 & --- & -- \\
Oleo Vegetal & 12,5 & 10,0 & 10,0 & 17,5 \\
Milho Moído (8,2\% PB) & 112,5 & 167,5 & 170,0 & 222,5 \\
Farelo de Soja (45,5\%PB) & 75,0 & 120,0 & 120,0 & 135,0 \\
TOTAL (Kg) & 500,0 & 500,0 & 500,0 & 500,0 \\
\hline
\end{tabular}

Nota 1: (R.SU.PR1) Ração Pré-Inicial- 1: Fornecido de 07 a 24 dias de idade

Nota 2: (R.SU.PR2) Ração Pré-Inicial- 2: Fornecido de 25 a 35 dias de idade

Nota 3: (R.SU.IN1) Ração Inicial- 1: Fornecido de 36 a 46 dias de idade

Nota 4: Multimaternidade 600: Composto de farelo de glúten de milho, milho prégelatinizado, farelo de soja, fosfato bicálcio, DL-metionina, L-lisina, L-treonina, aditivo acidificante, aditivo flavorizante, aditivo palatabilizante, aditivo promotor de crescimento, soro de leite em pó, açúcar, cloreto de sódio, lactose, milho pré-gelatinizado, premix mineral, premix vitamínico,cloreto de colina

Nota 5: Multimaternidade 400 com ADO: farelo de glúten de milho, milho prégelatinizado, farelo de soja, fosfato bicálcio, DL-metionina, L-lisina, L-treonina, aditivo acidificante, aditivo flavorizante, aditivo palatabilizante, aditivo promotor de crescimento, soro de leite em pó, açúcar, cloreto de sódio, lactose, premix mineral, premix vitamínico,cloreto de colina 
Nota 6: Multicreche: Composto de farelo de glúten de milho, farelo de soja, milho prégelatinizado, fosfato bicálcio, DL-metionina, L-lisina, soro de leite em pó, Ltreonina, aditivo acidificante, aditivo flavorizante, aditivo palatabilizante, aditivo promotor de crescimento, premix mineral, premix vitaminico, cloreto de sódio, cloreto de colina

Nota 7: Multidesmame: Composto de vitamina A, óxido de zinco, DL-metionina, Llisina, aditivo promotor de crescimento

Tabela 4. Composição das dietas oferecidas aos suínos na fase de 47 a 175 dias

\begin{tabular}{lccc}
\hline INGREDIENTES (kg) & R.SU.IN2 & R.SU.CRE & R.SU.TER \\
\hline Multisuíno inicial & 2,0 & --- & -- \\
Multisuíno Crescimento & --- & 2,0 & --- \\
Multisuíno Terminação & --- & --- & 2,0 \\
Multimineral Suínos & 0,5 & 0,5 & 0,5 \\
Óleo Vegetal & 9,0 & 6,0 & -- \\
Açúcar & 20,0 & --- & --- \\
Milho Moído (8,2\% PB) & 270,0 & 320,0 & 365,0 \\
Farelo de soja (45,5\%PB) & 186,0 & 159,0 & 20,0 \\
Farelo de Trigo & --- & 30,0 & --- \\
Fosfato de cálcio & 7,0 & 6,0 & 5,0 \\
Calcário (37\% Ca) & 3,0 & 4,0 & 5,0 \\
Sal Moído & 2,5 & 2,5 & 2,5 \\
TOTAL (Kg) & 500,0 & 500,0 & 500,0 \\
\hline
\end{tabular}

Nota 1: (R.SU.IN2) Ração Inicial-2: Fornecido de 47 a 70 dias de idade Nota 2: (R.SU.CRE) Ração Crescimento: Fornecido de 71 a 120 dias de idade 
Nota 3: (R.SU.TER) Ração Terminação: Fornecido de 121 a 175 dias de idade

Nota 4: Multisuíno inicial: suplemento vitamínico para suíno composto de vitamina A, vitamina D3, vitamina E, vitamina K3, vitamina B1, Vitamina B2, Vitamina B6, vitamina B12, niacina, ácido fosfórico, pantotenato de cálcio, cloreto de colina, biotina, aditivo promotor de crescimento, aditivo antioxidante

Nota 5: Multisuíno crescimento: suplemento vitamínico para suíno composto de vitamina $A$, vitamina $D 3$, vitamina $E$, vitamina $K 3$, vitamina $B 1$, Vitamina $B 2$, Vitamina B6, vitamina B12, niacina, pantotenato de cálcio, cloreto de colina, aditivo promotor de crescimento, aditivo antioxidante

Nota 6: Multisuíno terminação: suplemento vitamínico para suíno composto de vitamina A, vitamina D3, vitamina E, vitamina K3, vitamina B1, Vitamina B2, vitamina B12, niacina, pantotenato de cálcio, cloreto de colina, aditivo promotor de crescimento, aditivo antioxidante

Nota 7: Multimineral suíno: suplemento mineral para suíno composto de sulfato de ferro, sulfato de magnésio, óxido de zinco, sulfato de cobre, iodato de cálcio, selenito de sódio

\subsection{Abate}

Os ensaios de desempenho foram realizados na Granja MULTIMIX em Patrocínio (MG), onde 96 suínos foram distribuídos em dezesseis tratamentos, variando o genótipo, sexo e peso de abate.

O transporte dos animais da granja para o abatedouro foi feito em caminhões de carroceria simples, no período da noite, percorrendo uma distância aproximada de $25 \mathrm{~km}$. Os animais foram abatidos no dia seguinte mantendo um período de jejum de 14 a 16 horas. Foi empregada a insensibilização elétrica com tensão variando na faixa entre $220 \pm 20 \mathrm{~V}$ e $60 \mathrm{~Hz}$ de freqüência. A insensibilização foi aplicada com o animal no limitador e um tempo de contato dos eletrodos na cabeça do animal (posicionados na base 
das orelhas) entre 1 a 2 segundos. $O$ abate foi efetuado com animais entre 145 e 175 dias de idade, com um peso do animal vivo próximo a 100 (peso leve) e $120 \mathrm{~kg}$ (peso pesado), respectivamente.

A sangria foi realizada imediatamente após a insensibilização com o animal posicionado na horizontal, sendo que o mesmo permaneceu nesta posição durante um período equivalente a 2 minutos e a seguir foi suspenso até o trilho para prosseguirem as outras operações de abate. Após o espotejamento e desossa, os cortes (lombo, coxão mole) provenientes do lado esquerdo da carcaça foram utilizados para a determinação dos preditores de qualidade $\mathrm{pH}$, capacidade de retenção de água e perda por exsudação. O lombo da meia carcaça direita foi usado para a determinação da cor.

As avaliações referentes à composição de carcaça corresponderam às medidas das espessuras de músculo (EM) e de gordura costo-lombar (EG) realizadas com o auxílio de instrumentação ótica bem como às medidas de área de olho de lombo ( $A O L)$, comprimento de olho do lombo ( $C O L)$, profundidade de toucinho (PT), peso da carcaça resfriada (PCR). A quantidade de carne presente na carcaça foi obtida pelo método da desossa dos cortes primários (paleta, sobrepaleta, carré, barriga e pernil), obtendo-se, desta maneira, a porcentagem de carne magra da carcaça (\%CM). As características de qualidade da carne executadas na empresa PIF PAF, em Minas gerais, foram o $\mathrm{pH}$ medido 1 hora $\left(\mathrm{pH}_{1}\right)$ e 24 horas post mortem $\left(\mathrm{pH}_{24}\right)$, perda por exsudação (PE) e capacidade de retenção de água (CRA). A composição da cor ( $L^{*}=$ luminosidade; $\mathrm{a}^{\star}=$ teor de vermelho; $\mathrm{b}^{*}=$ teor de amarelo), executada com o auxílio do colorímetro Minolta e a leitura da CRA com o planímetro foram as avaliações de qualidade realizadas no Centro de Tecnologia de Carnes do ITAL em Campinas.

O fluxograma do processo de abate está ilustrado na Figura 7 e o mesmo permite visualizar as amostragens e medições realizadas neste experimento. 
Recepção dos animais

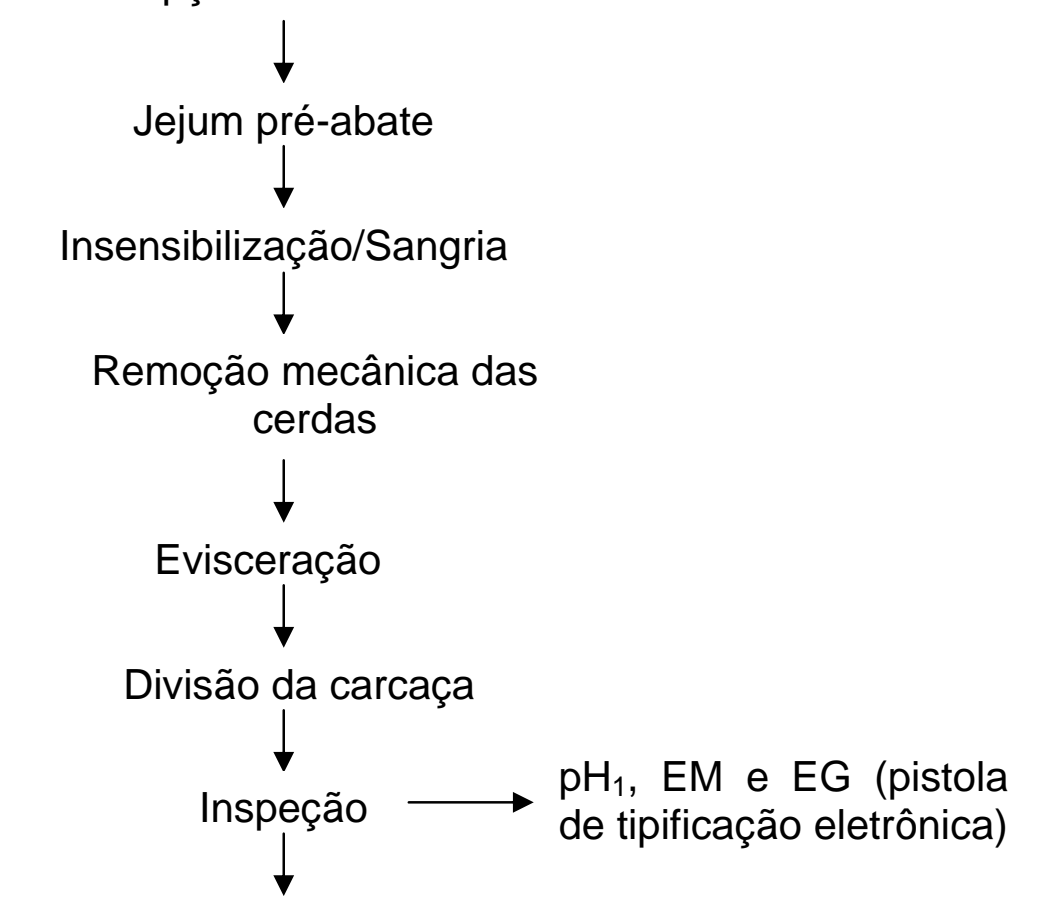

Tipificação eletrônica/pesagem
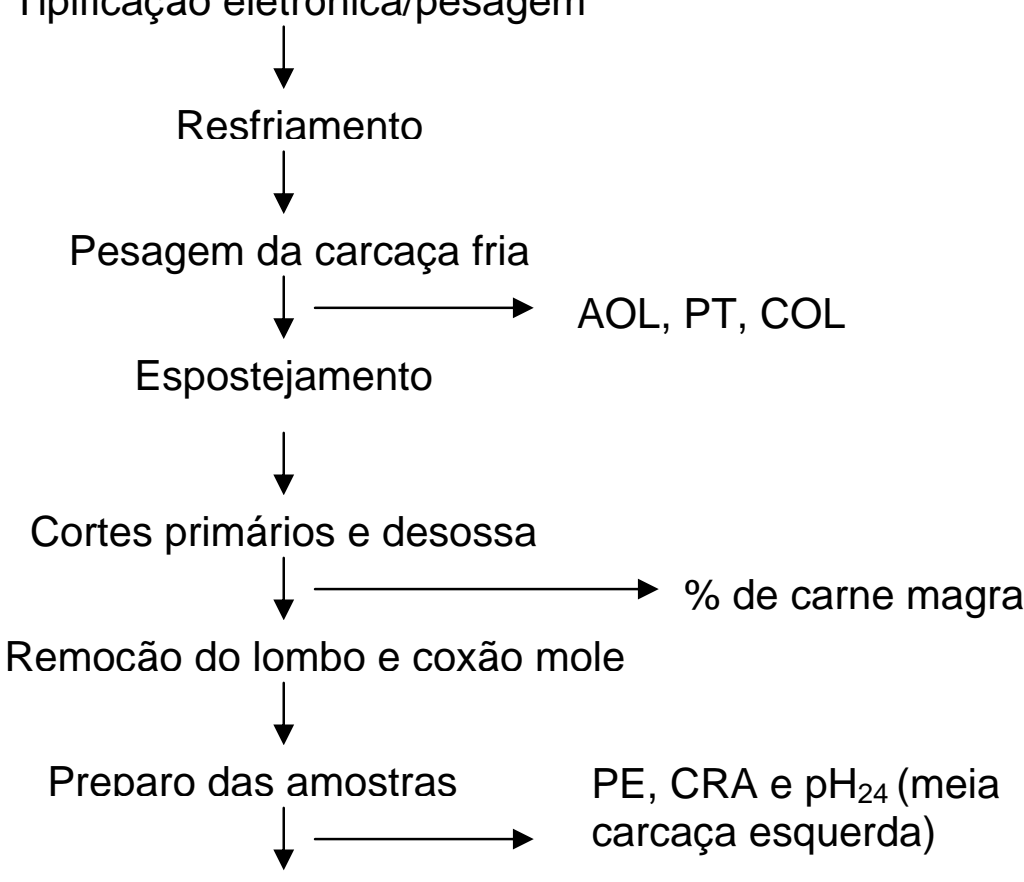

Acondicionamento a vácuo do lombo (meia carcaça direita)

Congelamento e posterior envio das amostras ao ITAL

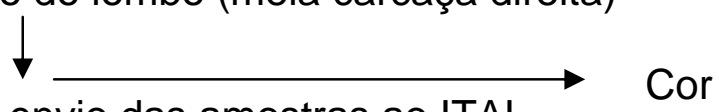

Figura 7 - Fluxograma do processo de abate 
O delineamento experimental foi inteiramente casualizado, com tratamentos em esquema fatorial $4 \times 2 \times 2$ (4 genótipos $\times 2$ sexos $\times 2$ pesos) e 6 repetições.

Os tratamentos investigados estão descritos a seguir:

Tratamento 1. Nesse tratamento, foram destinados 6 leitões do genótipo $\mathrm{Nn}$ machos castrados desmamados pesando em média $5 \mathrm{~kg}$ de peso vivo. Os animais receberam ração balanceada em nutrientes até atingirem o peso de abate de $100 \mathrm{~kg}$.

Tratamento 2. Nesse tratamento foram destinados 6 leitões do genótipo $\mathrm{Nn}$ machos castrados desmamados pesando em média $5 \mathrm{~kg}$ de peso vivo. Os animais receberam ração balanceada em nutrientes até atingirem o peso de abate de $120 \mathrm{~kg}$.

Tratamento 3. Nesse tratamento foram destinados 6 leitões do genótipo $\mathrm{Nn}$ fêmeas desmamadas pesando em média $5 \mathrm{~kg}$ de peso vivo. Os animais receberam ração balanceada em nutrientes até atingirem o peso de abate de $100 \mathrm{~kg}$.

Tratamento 4. Nesse tratamento foram destinados 6 leitões do genótipo $\mathrm{Nn}$ fêmeas desmamadas pesando em média $5 \mathrm{~kg}$ de peso vivo. Os animais receberam ração balanceada em nutrientes até atingirem o peso de abate de $120 \mathrm{~kg}$.

Tratamento 5. Nesse tratamento foram destinados 6 leitões do genótipo nn machos castrados desmamados pesando em média $5 \mathrm{~kg}$ de peso vivo. Os animais receberam ração balanceada em nutrientes até atingirem o peso de abate de $100 \mathrm{~kg}$.

Tratamento 6. Nesse tratamento foram destinados 6 leitões do genótipo nn machos castrados desmamados pesando em média $5 \mathrm{~kg}$ de peso vivo. Os 
animais receberam ração balanceada em nutrientes até atingirem o peso de abate de $120 \mathrm{~kg}$.

Tratamento 7. Nesse tratamento foram destinados 6 leitões do genótipo nn fêmeas desmamadas pesando em média $5 \mathrm{~kg}$ de peso vivo. Os animais receberam ração balanceada em nutrientes até atingirem o peso de abate de $100 \mathrm{~kg}$.

Tratamento 8. Nesse tratamento foram destinados 6 leitões do genótipo nn fêmeas desmamadas pesando em média $5 \mathrm{~kg}$ de peso vivo. Os animais receberam ração balanceada em nutrientes até atingirem o peso de abate de $120 \mathrm{~kg}$.

Tratamento 9. Nesse tratamento foram destinados 6 leitões do genótipo $\mathrm{NN}_{\mathrm{M}}$ machos castrados desmamados pesando em média $5 \mathrm{~kg}$ de peso vivo. Os animais receberam ração balanceada em nutrientes até atingirem o peso de abate de $100 \mathrm{~kg}$.

Tratamento 10. Nesse tratamento foram destinados 6 leitões do genótipo $N_{M}$ machos castrados desmamados pesando em média $5 \mathrm{~kg}$ de peso vivo. Os animais receberam ração balanceada em nutrientes até atingirem o peso de abate de $120 \mathrm{~kg}$.

Tratamento 11. Nesse tratamento foram destinados 6 leitões do genótipo $N N_{M}$ fêmeas desmamadas pesando em média $5 \mathrm{~kg}$ de peso vivo. Os animais receberam ração balanceada em nutrientes até atingirem o peso de abate de $100 \mathrm{~kg}$.

Tratamento 12. Nesse tratamento foram destinados 6 leitões do genótipo $N N_{M}$ fêmeas desmamadas pesando em média $5 \mathrm{~kg}$ de peso vivo. Os animais receberam ração balanceada em nutrientes até atingirem o peso de abate de $120 \mathrm{~kg}$.

Tratamento 13. Nesse tratamento foram destinados 6 leitões do genótipo $\mathrm{NN}_{\mathrm{O}}$ machos castrados desmamados pesando em média $5 \mathrm{~kg}$ de peso vivo. Os 
animais receberam ração balanceada em nutrientes até atingirem o peso de abate de $100 \mathrm{~kg}$.

Tratamento 14. Nesse tratamento foram destinados 6 leitões do genótipo $N_{\circ}$ machos castrados desmamados pesando em média $5 \mathrm{~kg}$ de peso vivo. Os animais receberam ração balanceada em nutrientes até atingirem o peso de abate de $120 \mathrm{~kg}$.

Tratamento 15. Nesse tratamento foram destinados 6 leitões do genótipo $\mathrm{NN}_{\mathrm{O}}$ fêmeas desmamadas pesando em média $5 \mathrm{~kg}$ de peso vivo. Os animais receberam ração balanceada em nutrientes até atingirem o peso de abate de $100 \mathrm{~kg}$.

Tratamento 16. Nesse tratamento foram destinados 6 leitões do genótipo $\mathrm{NN}_{\mathrm{O}}$ fêmeas desmamadas pesando em média $5 \mathrm{~kg}$ de peso vivo. Os animais receberam ração balanceada em nutrientes até atingirem o peso de abate de $120 \mathrm{~kg}$.

\subsection{Medidas de composição da carcaça}

\subsubsection{Peso da carcaça resfriada (PCR)}

As carcaças foram identificadas de acordo com o tratamento realizado e conduzidas a uma câmara de resfriamento $\left(0^{\circ}\right.$ a $\left.2^{\circ} \mathrm{C}\right)$ onde permaneceram por um período de 16 a 20 horas. Procedeu-se, a seguir, a pesagem na balança do frigorífico situada junto à plataforma de tipificação de carcaça. 


\subsection{2 Área de olho de lombo (AOL), comprimento de olho de lombo (COL) e profundidade de toucinho (PT)}

Esses preditores de quantidade de carne foram avaliados na meia-carcaça esquerda através de um corte realizado entre a $10^{\mathrm{a}}$ e a $11^{\mathrm{a}}$ costela, expondo, dessa forma, uma secção transversal do músculo Longissimus dorsi (LD).

O comprimento de olho de lombo ( $\mathrm{COL}$ ), representado por uma reta imaginária correspondente ao maior diâmetro da superfície exposta do LD, foi medido com o auxílio do paquímetro.

O local exato para medir a profundidade de toucinho (PT) é imaginar outra reta que corte a primeira utilizada na avaliação do $\mathrm{COL}$ a 3/4 de distância de sua extremidade dorsal, medindo-se perpendicularmente à pele até o ponto onde a segunda reta cruza o contorno do LD.

A área de olho de lombo ( $A O L$ ) foi medida utilizando-se uma matriz plástica formada por quadrados com uma área de $1 \mathrm{~cm}^{2}$ cada, obtendo-se a área total a partir da contagem dos quadrados que se encontram na superfície da carne.

\subsubsection{Tipificação eletrônica}

A tipificação eletrônica foi realizada a partir de uma sonda óptica inserida perpendicularmente a linha mediana da divisão da carcaça, obtendo-se, dessa forma, em milímetros, medidas de espessura de músculo (EM) e gordura (EG). Esta medida foi realizada na linha de matança, em três posições da meia carcaça esquerda: na altura da última costela (1), entre a última e a penúltima costela (2) e entre a terceira e a quarta últimas costelas (3). As leituras obtidas resultaram da inserção da sonda, 6 e $8 \mathrm{~cm}$ distantes da linha de divisão da 
carcaça (EM1,6, EG1,6, EM1,8, EG1,8, EM2,6, EG2,6, EM2,8, EG2,8, EM3,6, EG3,6, EM3,8, EG3,8).

\subsubsection{Desossa}

Inicialmente, a carcaça foi desossada em seus cortes primários: paleta, sobrepaleta, carré, barriga e pernil. Após a pesagem desses cortes, foi realizada a desossa dos mesmos, com exceção da barriga e da costela, separando-se, assim, a carne e a gordura de cada corte e realizando, posteriormente, a pesagem dos mesmos.

\subsubsection{Determinação da porcentagem de carne magra (\%CM)}

A determinação da porcentagem de carne foi obtida a partir dos cortes primários desossados obtidos das duas meias carcaças resfriadas. Para tanto, utilizou-se a soma do peso da carne do pernil, da paleta, da sobrepaleta, do lombo e do filezinho e este valor foi dividido pelo peso da carcaça resfriada. Como a barriga e as costelas não foram desossadas, separando a carne e a gordura correspondentes, foi adicionado o valor 4,5 na porcentagem final de carne com base em estudos de dissecações anteriores.

\subsection{Avaliações da qualidade de carne}

\subsection{1 pH}

Os valores de $\mathrm{pH}$ foram potenciometricamente mensurados utilizando-se pHmetro INGOLD WTW pH 91. 
As mensurações foram realizadas em triplicata nos músculos Semispinalis capitis e Semimembranosus das meias carcaças esquerdas, nos períodos de 1 e 24 horas post mortem.

\subsubsection{Cor}

A cor foi realizada nas amostras descongeladas do lombo, após 1 mês de estocagem congeladas, com o auxílio de um espectrofotômetro portátil MINOLTA, modelo CM 508d, diâmetro de abertura de $8 \mathrm{~mm}$, ângulo de leitura de $10^{\circ}$, iluminante D65 e componente especular incluído.

As mensurações foram realizadas em triplicata no músculo Longissimus dorsi das meias carcaças direitas, no sistema $L^{*} a^{*} b^{*}$, onde $L^{*}$ corresponde à luminosidade da carne, $a^{\star}$ ao teor de vermelho e $b^{\star}$ ao teor de amarelo.

\subsubsection{Perda por exsudação (PE)}

A perda por exsudação foi determinada nas amostras do músculo Longissimus dorsi das meias carcaças esquerdas, livres de gordura externa e tecida conectivo, conforme a metodologia descrita por Honikel (1987).

As amostras foram pesadas ( $\cong 100 \mathrm{~g})$ e suspensas numa rede de nylon no interior de um saco plástico. O conjunto foi mantido em câmara fria a $4^{\circ} \mathrm{C}$ por 48horas. Expressou-se o valor da perda por exsudação em porcentagem, obtida através da diferença dos pesos inicial e final, dividido pelo peso inicial da amostra e multiplicado por 100.

\subsubsection{Capacidade de retenção de água (CRA)}

A capacidade de retenção de água foi realizada empregando-se a metodologia descrita por Grau \& Hamm (1954) e modificada por Hofmann et al (1982). 
Amostras de 0,500+/- 0,0005 do músculo Semimenbranosus foram retiradas das meias carcaças esquerdas no período de 24horas post mortem, sendo posteriormente colocadas entre dois papéis de filtro Wathman $n^{\circ} 1$, entre placas de plexiglass. Esse conjunto foi colocado numa prensa hidráulica e aplicou-se a pressão equivalente a $500 \mathrm{lb} / \mathrm{pol}^{2}$, durante 2 minutos. A leitura da CRA foi realizada com o auxílio de um planímetro e o valor de G encontrado corresponde a área da carne/área do exsudato.

\subsection{Análise estatística}

Com o objetivo de verificar a influência do genótipo, sexo e peso de abate nas características de carcaça, qualidade e quantidade de carne, foi realizada análise de variância (ANOVA). A comparação entre as médias dos genótipos estudados foi realizada mediante o teste de Tukey a um nível de significância de 5\%, utilizando o Programa SAS-STATISTICS (1985). Não foi utilizado o teste de Tukey para testar diferenças entre duas médias, já que o $\mathrm{F}$ da análise de variância, nesses casos, é igual a t2 (t de Student). 


\section{RESULTADOS E DISCUSSÃO}

Os resultados da composição da carcaça (Tabelas 5, 6, 7, 8, 9, 10, 11, 12) e qualidade de carne (Tabelas 13, 14, 15, 16), provenientes do abate de 96 suínos, estão apresentados e discutidos a seguir.

\subsection{Influência do genótipo, sexo e peso de abate na composição da carcaça}

A Tabela 5 contém os resultados estatísticos do PCR, AOL, PT, COL e \%CM em função dos tratamentos estudados.

Os resultados do presente estudo indicam que os genótipos nn e $\mathrm{NN}_{\mathrm{O}}$ apresentaram os maiores pesos de carcaça resfriada (PCR) comparados com $\mathrm{Nn}$ e $\mathrm{NN}_{\mathrm{M}}$. Resultados diferentes foram relatados por Leach et. al., (1996), que reportaram maior PCR para os animais carregadores do gene halotano $(\mathrm{Nn})$ do que os negativos (NN) para gene (91,6 x 90,4, respectivamente). No entanto, Cisneros et. al., (1996) não encontraram efeito do genótipo no PCR. Na presente investigação, os machos apresentaram maior PCR que as fêmeas. Beattie et. al., (1999), Suzuki et. al., (2003) e Cisneros et. al., (1996) não encontraram diferença significativa entre os sexos com relação a esta característica. O PCR dos animais pesados, no presente estudo, foi 16\% maior que dos animais leves. Valores superiores foram relatados por Beattie et. al., (1999), onde animais leves $(105 \mathrm{Kg})$ e pesados (118 Kg) apresentaram médias de PCR de 89 e $100 \mathrm{Kg}$, respectivamente. 
Entre as características de carcaça avaliadas, destacam-se a Área de Olho de Lombo (AOL) e a Profundidade de Toucinho (PT), as quais, normalmente, têm alta correlação com a quantidade de carne presente na carcaça (Felício, 1986).

Nesse sentido, os suínos nn apresentaram valor de $\mathrm{AOL}$ significativamente maior do que os animais $\mathrm{Nn}, \mathrm{NN}_{\mathrm{M}}$ e $\mathrm{NN}_{\mathrm{O}}$. Esse resultado evidencia a maior musculosidade de nn e corrobora com os estudos conduzidos por Fischer et. al., (2000), Jones et. al., (1988) e Simpson e Webb, (1989) que também reportaram valores maiores de $\mathrm{AOL}$ para o genótipo nn, intermediários para Nn e menores para NN. Resultados similares foram também apresentados por Leach et. al., (1996), Murray et. al., (1989), Fischer (1995), Pommier et. al., (1992) e Sather et. al., (1991). Na presente investigação, constatou-se que os animais pesados tiveram um aumento de 9,12\% na AOL em relação aos animais leves. Beattie et. al., (1999) e Sutton et. al., (1997) reportaram valores inferiores para esta característica, sendo $42,6 \mathrm{~cm}^{2}$ e $41,5 \mathrm{~cm}^{2}$ para animais leves e $44,5 \mathrm{~cm}^{2}$ e $47,17 \mathrm{~cm}^{2}$ para animais pesados, respectivamente.

Quanto à Profundidade de Toucinho (PT), os animais nn apresentaram o menor valor, diferindo significativamente de $\mathrm{NN}_{\mathrm{M}}$ e do $\mathrm{NN}_{\mathrm{O}} \mathrm{O}$ O genótipo $\mathrm{Nn}$ mostrou uma PT que não diferiu dos genótipos em estudo. Resultados similares foram relatados por Leach et. al., (1996), Pommier et. al., (1992), Sather et. al., (1991) e Bowker et. al., (1999). Sutton et. al., (1997), Webb et. al., (1994) e Pommier et. al., (1993) também não encontraram diferenças entre os genótipos NN e Nn quanto a PT. No presente estudo, os machos apresentaram uma PT $26 \%$ maior que a das fêmeas. Resultados superiores para essa característica foram encontrados por Berg et. al., (2003), onde os machos apresentaram maior PT $(2,76 \mathrm{~cm})$ que as fêmeas $(2,27 \mathrm{~cm})$. Candek-Potokar et. al., (2002) também relataram serem as carcaças dos machos mais gordas que as das fêmeas. Com relação ao peso de abate, é esperado que os animais pesados depositem mais gordura na carcaça, como foi constatado neste trabalho, onde a PT aumentou 13\% nos animais pesados em relação aos animais leves. Sutton 
et. al., (1997) encontraram maiores valores para essa medida, sendo 1,94cm e $2,48 \mathrm{~cm}$ para animais leves e pesados, respectivamente.

Em relação à porcentagem de carne magra na carcaça (\%CM), os genótipos nn e $\mathrm{Nn}$ mostraram valores significativamente maiores aos obtidos pelos genótipos $\mathrm{NN}_{\mathrm{M}}$ e $\mathrm{NN}_{\mathrm{O}}$, que apresentaram valores de \%CM 3,08\% e $4,61 \%$ menores do que o genótipo $\mathrm{nn}$, respectivamente. Resultados similares foram relatados por Fisher et. al., (2000) e De Smet et. al., (1996). Apesar dos valores de \% de CM dos genótipos nn e $\mathrm{Nn}$, encontrados no presente estudo, não diferirem significativamente, o acréscimo de 1,3\% de carne magra observado no genótipo nn em relação ao Nn é expressivo quando se considera o abate anual de suínos. Constatou-se, ainda, que os animais leves apresentaram 1,26\% a mais de CM que os animais pesados. Estes resultados corroboram com os reportados por Beattie et. al. (1999), onde a proporção de carne magra foi menor nos animais pesados (90 e 100Kg) em relação aos leves (70 e $80 \mathrm{Kg}$ ). 
Tabela 5. Médias dos tratamentos na composição da carcaça

\begin{tabular}{|c|c|c|c|c|c|c|c|c|c|c|c|c|}
\hline \multirow[b]{2}{*}{ Variável } & \multicolumn{4}{|c|}{ Genótipo } & \multicolumn{2}{|c|}{ Sexo } & \multicolumn{2}{|c|}{ Peso } & \multicolumn{3}{|c|}{ valor $p$} & \multirow{2}{*}{ Interações $^{a}$} \\
\hline & $\mathrm{Nn}$ & $\mathrm{nn}$ & $\mathrm{NN}_{\mathrm{M}}$ & $\mathrm{NN}_{\mathrm{O}}$ & $\mathrm{F}$ & $\mathrm{M}$ & L & $\mathrm{P}$ & G & $\mathrm{S}$ & $\mathrm{P}$ & \\
\hline PCR & $84,22 b$ & $86,06 a b$ & $83,69 b$ & $87,76 a$ & $82,68 d$ & $88,18 \mathrm{c}$ & $79,02 f$ & $91,84 \mathrm{e}$ & 0,0041 & 0,0001 & 0,0001 & $\mathrm{GxS}^{*} ; \mathrm{GxP}^{*} ; \mathrm{SxP}^{*}$ \\
\hline AOL & $46,17 b$ & $52,10 a$ & $46,79 b$ & $46,46 b$ & $47,35 c$ & $48,40 c$ & $45,79 f$ & $49,97 e$ & 0,002 & 0,3915 & 0,001 & $G x P^{*}$ \\
\hline $\mathrm{T}$ & $1,78 a b$ & $1,53 b$ & $2,16 a$ & $2,08 a$ & $1,67 d$ & $2,11 c$ & $1,77 f$ & $2,01 \mathrm{e}$ & 0,001 & 0,0003 & 0,0392 & $G \times P^{*}$ \\
\hline COL & $8,70 b$ & $9,66 a$ & $9,43 a$ & $9,28 a$ & $9,27 c$ & $9,27 c$ & $9,15 f$ & $9,39 e$ & 0,0001 & 0,9701 & 0,0756 & $G \times P^{*}$ \\
\hline$\% \mathrm{CM}$ & $50,59 a$ & $51,83 a$ & $48,75 b$ & $47,22 \mathrm{~b}$ & $49,74 \mathrm{c}$ & $49,42 c$ & $50,20 \mathrm{e}$ & $48,94 f$ & 0,0001 & 0,584 & 0,0165 & GxS*; GxP* \\
\hline
\end{tabular}

Nota 1: F: fêmeas; M: machos; L: leves; P: pesados; G: genótipo; S: sexo; P: peso

Nota 2: Médias dentro de uma mesma linha, seguidas de letras diferentes (a-b), são estatisticamente diferentes para genótipo, no nível de $5 \%$ de significância $(p<0,05)$.

Nota 3: Médias dentro de uma mesma linha, seguidas de letras diferentes (c-d), são estatisticamente diferentes para sexo, no nível de $5 \%$ de significância $(p<0,05)$.

Nota 4: Médias dentro de uma mesma linha, seguidas de letras diferentes (e-f), são estatisticamente diferentes para peso, no nível de $5 \%$ de significância $(p<0,05)$.

${ }^{a} p<0,05$. 
Os dados estatísticos obtidos na tipificação eletrônica estão contidos nas Tabelas 6 e 7.

A análise dos dados apresentados na Tabelas 6 revelou que houve uma tendência dos animais pertencentes ao genótipo $\mathrm{NN}_{\mathrm{M}}$ apresentarem as maiores $\mathrm{EM}$, sendo que os animais do genótipo $\mathrm{NN}_{\mathrm{O}}$ obtiveram os menores valores para essa característica. Com relação aos valores de EG (Tabela 7), os maiores foram apresentados pelo genótipo $\mathrm{NN}_{\mathrm{O}}$ e os menores, por $\mathrm{Nn}$, para todas as posições onde foram realizadas as medidas.

Pela análise dos resultados obtidos para EM e EG, os suínos pertencentes ao genótipo $\mathrm{Nn}$ apresentaram uma maior proporção de músculo/gordura na carcaça, sendo esta proporção menor nas carcaças dos animais do genótipo $\mathrm{NN}_{\mathrm{O}}$, os quais mostraram carcaças mais gordas. Latorre et. al., (2003) avaliaram o genótipo proveniente do cruzamento de Pietrain $x$ Large White e encontraram valores similares de espessuras de gordura $(22,5 \mathrm{~mm}$ e $18,6 \mathrm{~mm}$ ) aos encontrados no presente estudo para os genótipos $\mathrm{Nn}, \mathrm{NN}_{\mathrm{M}}$ e $\mathrm{NN}_{\mathrm{O}}$, também provenientes de cruzamento entre Pietrain e Large White.

A avaliação da EM e EG a $6 \mathrm{~cm}$ e $8 \mathrm{~cm}$ da divisão longitudinal da carcaça mostrou uma coerência na tendência das faixas de valores obtidas, desde que EG menor resultou em EM maior. Assim, medidas obtidas a $6 \mathrm{~cm}$ situam-se numa faixa de EG menor e EM maior do que a $8 \mathrm{~cm}$.

Com relação ao peso de abate, os animais pesados apresentaram valores significativamente maiores em relação aos leves para as espessuras de gordura e de músculo nas posições EM1,6, EG1,8, EM1,8, EM2,6, EM2,8, EM3,6, EM3,8. Beattie et. al., (1999) reportaram aumento nas espessuras de gordura com o aumento do peso de abate. Os valores de EG1,6, EG1,8, $E G 2,6, E G 2,8, E G 3,6$ e EG3,8, encontrados no presente estudo, foram significativamente maiores para os machos, indicando que eles apresentaram mais gordura na carcaça que as fêmeas. Resultados similares foram encontrados por Latorre et. al. (2003), D'Souza et. al. (2002), Fisher et. al. 
(2000), Fortin (1980), Leach et. al. (1996), Cisneros et. al. (1996), Friesen et. al. (1994) e Nieuwhof et. al. (1991). 
Tabela 6. Médias dos tratamentos nas espessuras de músculo (EM) obtidas pela tipificação eletrônica

\begin{tabular}{|c|c|c|c|c|c|c|c|c|c|c|c|c|}
\hline \multirow[b]{2}{*}{ Variável } & \multicolumn{4}{|c|}{ Genótipo } & \multicolumn{2}{|c|}{ Sexo } & \multicolumn{2}{|c|}{ Peso } & \multicolumn{3}{|c|}{ valor $p$} & \multirow[b]{2}{*}{ Interações } \\
\hline & $\mathrm{Nn}$ & $\mathrm{nn}$ & $\mathrm{NN}_{\mathrm{M}}$ & $\mathrm{NN}_{\mathrm{O}}$ & $\mathrm{F}$ & $\mathrm{M}$ & $\mathrm{L}$ & $\mathrm{P}$ & G & $\mathrm{S}$ & $\mathrm{P}$ & \\
\hline EM1,6 & $64,46 a$ & $66,06 a$ & $66,18 a$ & $62,99 a$ & $63,94 \mathrm{c}$ & $65,90 \mathrm{c}$ & $61,14 \mathrm{f}$ & $68,71 \mathrm{e}$ & 0,2938 & 0,1482 & 0,0001 & - \\
\hline EM1,8 & $60,77 a$ & $59,52 a$ & $62,13 a$ & $56,89 a$ & $59,89 c$ & $59,76 c$ & $55,80 \mathrm{f}$ & $63,86 \mathrm{e}$ & 0,1217 & 0,9317 & 0,0001 & - \\
\hline EM2,6 & $63,53 a b$ & $62,02 \mathrm{ab}$ & $65,38 a$ & $60,46 b$ & $62,67 c$ & $63,03 c$ & $58,85 \mathrm{f}$ & $66,85 e$ & 0,0493 & 0,7797 & 0,0001 & - \\
\hline EM2,8 & $60,05 a b$ & $55,52 b$ & $61,72 a$ & $55,30 b$ & $58,24 c$ & $58,05 c$ & $53,33 \mathrm{f}$ & $62,96 \mathrm{e}$ & 0,007 & 0,9051 & 0,0001 & - \\
\hline EM3,6 & $62,66 a b$ & $59,10 b$ & $63,52 a$ & $58,93 b$ & $60,41 c$ & $61,70 \mathrm{c}$ & $56,57 \mathrm{f}$ & $65,53 e$ & 0,01 & 0,2799 & 0,0001 & - \\
\hline EM3,8 & $58,70 a b$ & $55,27 a b$ & $60,55 a$ & $53,66 b$ & $56,14 c$ & $57,95 c$ & $52,43 \mathrm{f}$ & $61,66 \mathrm{e}$ & 0,0086 & 0,2428 & 0,0001 & - \\
\hline
\end{tabular}

Nota 1: F: fêmeas; M: machos; L: leves; P: pesados; G: genótipo; S: sexo; P: peso.

Nota 2: Médias dentro de uma mesma linha, seguidas de letras diferentes (a-b), são significativamente diferentes para genótipo, no nível de $5 \%$ de significância $(p<0,05)$.

Nota 3: Médias dentro de uma mesma linha, seguidas de letras diferentes (c-d), são significativamente diferentes para sexo, no nível de $5 \%$ de significância $(p<0,05)$.

Nota 4: Médias dentro de uma mesma linha, seguidas de letras diferentes (e-f), são significativamente diferentes para peso, no nível de $5 \%$ de significância $(p<0,05)$.

${ }^{\mathrm{a}} \mathrm{p}<0,05$. 
Tabela 7. Médias dos tratamentos nas espessuras de gordura (EG) obtidas pela tipificação eletrônica

\begin{tabular}{|c|c|c|c|c|c|c|c|c|c|c|c|c|}
\hline \multirow[b]{2}{*}{ Variável } & \multicolumn{4}{|c|}{ Genótipo } & \multicolumn{2}{|c|}{ Sexo } & \multicolumn{2}{|c|}{ Peso } & \multicolumn{3}{|c|}{ valor $p$} & \multirow[b]{2}{*}{ Interações $^{a}$} \\
\hline & $\mathrm{Nn}$ & $\mathrm{nn}$ & $\mathrm{NN}_{\mathrm{M}}$ & $\mathrm{NN}_{\mathrm{O}}$ & $\mathrm{F}$ & $\mathrm{M}$ & $\mathrm{L}$ & $\mathrm{P}$ & G & $\mathrm{S}$ & $P$ & \\
\hline EG1,6 & $16,97 \mathrm{a}$ & $18,84 \mathrm{a}$ & $18,53 a$ & $20,06 a$ & $16,93 d$ & $20,27 c$ & $18,09 e$ & $19,11 \mathrm{e}$ & 0,0832 & 0,0001 & 0,2253 & - \\
\hline EG1,8 & $18,17 b$ & $21,21 \mathrm{a}$ & $20,47 a b$ & $21,62 a$ & $18,75 d$ & $21,98 c$ & $19,42 \mathrm{f}$ & $21,31 \mathrm{e}$ & 0,0142 & 0,0001 & 0,0195 & - \\
\hline EG2,6 & $16,28 \mathrm{~b}$ & $16,97 a b$ & $18,07 a b$ & $19,45 a$ & $15,83 d$ & $19,55 c$ & $17,15 e$ & $18,23 e$ & 0,0349 & 0,0001 & 0,1772 & - \\
\hline EG2,8 & $17,32 \mathrm{~b}$ & $18,48 a b$ & $19,62 a b$ & $21,52 a$ & $17,74 \mathrm{~d}$ & $20,91 c$ & $18,59 e$ & $20,06 e$ & 0,0054 & 0,0002 & 0,0773 & - \\
\hline EG3,6 & $16,23 \mathrm{~b}$ & $17,09 a b$ & $17,63 a b$ & $19,26 a$ & $16,39 d$ & $18,71 \mathrm{c}$ & $17,17 \mathrm{e}$ & $17,93 e$ & 0,0468 & 0,0034 & 0,3212 & - \\
\hline EG3,8 & $16,63 \mathrm{~b}$ & $18,69 \mathrm{ab}$ & $19,10 a b$ & $20,96 a$ & $17,12 \mathrm{~d}$ & $20,57 \mathrm{c}$ & $18,49 \mathrm{e}$ & $19,20 \mathrm{e}$ & 0,0024 & 0,0001 & 0,3696 & - \\
\hline
\end{tabular}

Nota 1: F: fêmeas; M: machos; L: leves; P: pesados; G: genótipo; S: sexo; P: peso.

Nota 2: Médias dentro de uma mesma linha, seguidas de letras diferentes (a-b), são significativamente diferentes para genótipo, no nível de $5 \%$ de significância $(p<0,05)$.

Nota 3: Médias dentro de uma mesma linha, seguidas de letras diferentes (c-d), são significativamente diferentes para sexo, no nível de $5 \%$ de significância $(p<0,05)$.

Nota 4: Médias dentro de uma mesma linha, seguidas de letras diferentes (e-f), são significativamente diferentes para peso, no nível de $5 \%$ de significância $(p<0,05)$.

${ }^{\mathrm{a}} \mathrm{p}<0,05$. 
As interações estatisticamente significativas para a composição da carcaça estão apresentadas nas Tabelas 8, 9, 10, 11 e 12.

Houve interação significativa entre genótipo e sexo no PCR (Tabela 8) e \%CM (Tabela 9). As fêmeas pertencentes ao genótipo $\mathrm{NN}_{\mathrm{O}}$ apresentaram valor de PCR significativamente maior do que as fêmeas dos genótipos nn, Nn e $\mathrm{NN}_{\mathrm{M}}$, aproximando-se muito dos valores de PCR obtidos para os machos, conflitando com o que acontece geralmente na prática. Fisher et. al., (2000) não encontraram interação estatisticamente significativa entre genótipo e sexo para nenhuma característica de composição de carcaça. Em relação à \%CM, os resultados apresentados pelas fêmeas dos genótipos nn e $\mathrm{Nn}$ foram significativamente maiores que $\mathrm{NN}_{\mathrm{M}}$ e $\mathrm{NN}_{\mathrm{O}}$. No caso dos machos, a \%CM dos suínos $\mathrm{NN}_{\mathrm{M}}$ não diferiu significativamente de $\mathrm{nn}$ e $\mathrm{Nn}$.

Houve interação entre genótipo e peso para as características PCR (Tabela 8), \%CM (Tabela 9), PT (Tabela 10), AOL (Tabela 11), e COL (Tabela 12). Os dados estatísticos dessa interação confirmam o efeito do gene halotano em homozigose no incremento da musculosidade tanto dos animais leves como dos animais pesados do genótipo nn, que apresentaram maiores valores de AOL e menores de PT que os outros genótipos estudados.

A porcentagem de carne magra $(\% \mathrm{CM})$ foi significativamente maior nos animais leves do genótipo nn que nos demais genótipos. Com relação aos animais pesados, os genótipos nn e $\mathrm{Nn}$ apresentaram os maiores valores, sendo que o genótipo nn não diferiu significativamente de $\mathrm{NN}_{\mathrm{O}}$. Foi verificado que somente os animais dos genótipos $\mathrm{Nn}$ e $\mathrm{NN}_{\mathrm{O}}$ se beneficiaram com o aumento do peso de abate, uma vez que os animais pesados dos genótipos $\mathrm{nn}$ e $\mathrm{NN}_{\mathrm{M}}$ apresentaram $6,76 \%$ e $7,24 \%$, respectivamente, a menos de carne magra na carcaça, em relação aos animais leves. 
Tabela 8. Médias das interações entre genótipo e sexo, genótipo e peso e sexo e peso no peso da carcaça resfriada (PCR)

\begin{tabular}{|c|c|c|c|c|c|c|c|c|c|}
\hline & & \multicolumn{4}{|c|}{ Genótipo } & \multirow{2}{*}{$\begin{array}{c}\text { Significância } \\
\text { (interação) }\end{array}$} & \multicolumn{2}{|c|}{ Peso } & \multirow{2}{*}{$\begin{array}{r}\text { Significância } \\
\text { (interação) }\end{array}$} \\
\hline & & $\mathrm{Nn}$ & $\mathrm{nn}$ & $\mathrm{NN}_{\mathrm{M}}$ & $\mathrm{NN}_{\mathrm{O}}$ & & L & $\mathrm{P}$ & \\
\hline \multirow{2}{*}{ Sexo } & $\mathrm{F}$ & $80,58 \mathrm{~b}$ & $82,37 b$ & $80,34 \mathrm{~b}$ & $87,42 a$ & * & $77,73 \mathrm{f}$ & $87,63 e$ & $*$ \\
\hline & $M$ & $87,86 \mathrm{a}$ & $89,75 \mathrm{a}$ & $87,03 \mathrm{a}$ & $88,09 a$ & ns & $80,31 \mathrm{f}$ & $96,05 e$ & * \\
\hline \multirow{2}{*}{ Peso } & $\mathrm{L}$ & $78,91 \mathrm{~cd}$ & $78,46 \mathrm{~cd}$ & $76,03 d$ & $82,66 c$ & * & & & \\
\hline & $\mathrm{P}$ & $89,52 \mathrm{c}$ & $93,65 \mathrm{c}$ & $91,34 \mathrm{c}$ & $92,85 \mathrm{c}$ & ns & & & \\
\hline
\end{tabular}

Nota 1: F: fêmeas; M: machos; L: leves; P: pesados; * : $p<0,05$; ns: não significativo

Nota 2: Médias dentro de uma mesma linha, seguidas de letras diferentes (a-b), são significativamente diferentes para interação genótipo $x$ sexo, no nível de $5 \%$ de significância $(p<0,05)$

Nota 3: Médias dentro de uma mesma linha, seguidas de letras diferentes (c-d), são significativamente diferentes para interação genótipo $x$ peso, no nível de $5 \%$ de significância $(p<0,05)$

Nota 4: Médias dentro de uma mesma linha, seguidas de letras diferentes (e-f), são significativamente diferentes para interação sexo x peso, no nível de $5 \%$ de significância $(p<0,05)$

Segundo informações fornecidas pela empresa Seghers Genetics do Brasil, todos os genótipos foram selecionados para alta deposição de carne magra na carcaça. Além disso, de acordo com essas informações, os genótipos Linha 21 (nn) e Linha $23\left(\mathrm{NN}_{\mathrm{M}}=\right.$ Linha 23 puro) são os que apresentam as maiores porcentagens de carne. Uma explicação para o fato de os animais pesados pertencentes aos genótipos nn e $\mathrm{NN}_{\mathrm{M}}$, conforme verificado no presente estudo, terem apresentado menores valores de \% $\mathrm{CM}$ que os 
animais leves pode ser que esses genótipos tenham alcançado um teto de deposição de CM com peso entre $95-100 \mathrm{Kg}$, não sendo beneficiados com o aumento do peso para $115-120 \mathrm{Kg}$ na deposição de carne magra na carcaça.

Tabela 9. Médias das interações entre genótipo e sexo e genótipo e peso na porcentagem de carne magra $(\% \mathrm{CM})$

\begin{tabular}{ccccccc}
\hline & & \multicolumn{4}{c}{ Genótipo } & Significância \\
\cline { 3 - 6 } & & $\mathrm{Nn}$ & $\mathrm{nn}$ & $\mathrm{NN} \mathrm{N}_{\mathrm{M}}$ & $\mathrm{NN}$ & (interação) \\
\hline \multirow{2}{*}{ Sexo } & $\mathrm{F}$ & $51,18 \mathrm{a}$ & $52,25 \mathrm{a}$ & $47,16 \mathrm{~b}$ & $48,17 \mathrm{~b}$ & $*$ \\
& $\mathrm{M}$ & $50,01 \mathrm{a}$ & $51,37 \mathrm{a}$ & $50,15 \mathrm{a}$ & $46,29 \mathrm{~b}$ & $*$ \\
\multirow{2}{*}{ Peso } & $\mathrm{L}$ & $49,51 \mathrm{de}$ & $53,56 \mathrm{c}$ & $50,58 \mathrm{~d}$ & $47,14 \mathrm{e}$ & $*$ \\
& $\mathrm{P}$ & $51,68 \mathrm{c}$ & $49,94 \mathrm{~cd}$ & $46,92 \mathrm{e}$ & $47,30 \mathrm{de}$ & $*$ \\
\hline
\end{tabular}

Nota 1: F: fêmeas; M: machos; L: leves; P: pesados; * $p<0,05$

Nota 2: Médias dentro de uma mesma linha, seguidas de letras diferentes (ab), são significativamente diferentes para interação genótipo $x$ sexo, no nível de $5 \%$ de significância $(p<0,05)$

Nota 3: Médias dentro de uma mesma linha, seguidas de letras diferentes (ce), são significativamente diferentes para interação genótipo x peso, no nível de $5 \%$ de significância $(p<0,05)$

Com relação à PT dos animais pesados, os genótipos $\mathrm{NN}_{\mathrm{M}}$ e $\mathrm{NN}_{\mathrm{O}}$ apresentaram valor significativamente maior que $\mathrm{Nn}$ e nn. Houve uma redução na PT dos animais pesados em relação aos leves, de 21,6\% e 5,96\% nos genótipos $\mathrm{Nn}$ e nn, respectivamente. Por outro lado, nos genótipos $\mathrm{NN}_{\mathrm{M}}$ e $\mathrm{NN}_{\mathrm{O}}$, os suínos pesados apresentaram um aumento no valor dessa característica em relação aos animais leves, sendo $44 \%$ no genótipo $\mathrm{NN}_{\mathrm{M}} \mathrm{e}$ $41,24 \%$ no genótipo $\mathrm{NN}_{\mathrm{O}}$. 
Tabela 10. Médias da interação entre genótipo e peso na profundidade de toucinho $(\mathrm{PT})$

\begin{tabular}{ccccccc}
\hline & & \multicolumn{4}{c}{ Genótipo } & \multirow{2}{*}{$\begin{array}{c}\text { Significância } \\
\text { (interação) }\end{array}$} \\
\cline { 2 - 6 } Peso & $\mathrm{Nn}$ & $\mathrm{nn}$ & $\mathrm{NN}_{\mathrm{M}}$ & $\mathrm{NN}$ & & $\mathrm{ns}$ \\
& $\mathrm{P}$ & $1,99 \mathrm{a}$ & $1,58 \mathrm{a}$ & $1,77 \mathrm{a}$ & $1,72 \mathrm{a}$ & \\
\hline
\end{tabular}

Nota 1: L: leves; P: pesados; ${ }^{*}: p<0,05 ;$ ns: não significativo

Nota 2: Médias dentro de uma mesma linha, seguidas de letras diferentes (ab), são significativamente diferentes para interação genótipo x peso, no nível de $5 \%$ de significância $(p<0,05)$

A análise dos dados referentes à interação entre genótipo e peso na $\mathrm{AOL}$ mostra que os animais leves do genótipo nn apresentaram maior valor para essa característica, não diferindo significativamente do genótipo $\mathrm{NN}_{\mathrm{O}}$. Esta mesma análise aponta um benefício no aumento do peso de abate no incremento da $\mathrm{AOL}$ nos genótipos $\mathrm{Nn}$, nn e $\mathrm{NN}_{\mathrm{M}}$. Porém, esse efeito benéfico não ocorreu nos animais do genótipo $\mathrm{NN}_{\mathrm{O}}$, que apresentaram o menor valor para essa característica.

Com relação ao COL, os animais pesados do genótipo nn apresentaram maior valor para essa característica, não diferindo significativamente do genótipo $\mathrm{NN}_{\mathrm{M}}$. Esta mesma análise aponta um benefício no aumento do peso de abate no incremento do COL nos genótipos $\mathrm{Nn}$, nn e $\mathrm{NN}_{\mathrm{M}}$. Porém, esse efeito benéfico não ocorreu nos animais do genótipo $\mathrm{NN}_{\mathrm{O}}$, que apresentaram o menor valor para essa característica. 
Tabela 11. Médias da interação entre genótipo e peso na área de olho de lombo $(\mathrm{AOL})$

\begin{tabular}{|c|c|c|c|c|c|c|}
\hline & & \multicolumn{4}{|c|}{ Genótipo } & \multirow{2}{*}{$\begin{array}{c}\text { Significância } \\
\text { (interação) }\end{array}$} \\
\hline & & $\mathrm{Nn}$ & $\mathrm{nn}$ & $\mathrm{NN}_{\mathrm{M}}$ & $\mathrm{NN}_{\mathrm{O}}$ & \\
\hline \multirow{2}{*}{ Peso } & $\mathrm{L}$ & $42,33 \mathrm{~b}$ & $51,00 \mathrm{a}$ & $42,58 \mathrm{~b}$ & $47,25 a b$ & * \\
\hline & $\mathrm{P}$ & $50,00 \mathrm{ab}$ & $53,20 a$ & $51,00 \mathrm{ab}$ & 45,66 b & * \\
\hline
\end{tabular}

Nota 1: L: leves; P: pesados; *: $p<0,05$

Nota 2: Médias dentro de uma mesma linha, seguidas de letras diferentes (ab), são significativamente diferentes para interação genótipo $x$ peso, no nível de $5 \%$ de significância $(p<0,05)$

Tabela 12. Médias da interação entre genótipo e peso no comprimento do olho de lombo (COL)

\begin{tabular}{ccccccc}
\hline & & \multicolumn{4}{c}{ Genótipo } & \multicolumn{2}{c}{ Significância } \\
& & $\mathrm{Nn}$ & $\mathrm{nn}$ & $\mathrm{NN}_{\mathrm{M}}$ & $\mathrm{NN} /$ & (interação) \\
\hline \multirow{2}{*}{ Peso } & $\mathrm{L}$ & $8,51 \mathrm{c}$ & $9,28 \mathrm{ab}$ & $9,12 \mathrm{abc}$ & $9,69 \mathrm{a}$ & $*$ \\
& $\mathrm{P}$ & $8,90 \mathrm{~b}$ & $10,05 \mathrm{a}$ & $9,73 \mathrm{a}$ & $8,87 \mathrm{~b}$ & $*$ \\
\hline
\end{tabular}

Nota 1: L: leves; P: pesados; *: $p<0,05$

Nota 2: Médias dentro de uma mesma linha, seguidas de letras diferentes (ac), são significativamente diferentes para interação genótipo $\times$ peso, no nível de $5 \%$ de significância $(p<0,05)$

A interação estatisticamente significativa entre sexo e peso é encontrada para o PCR e ocorre diferença de peso tanto no grupo de animais machos como fêmeas. Os valores de PCR encontrados, no presente estudo, para fêmeas (leves e pesadas) e machos (leves e pesados) são inferiores aos 
relatados por Beattie et. al., (1999), comparando-se animais abatidos na mesma faixa de peso vivo, sendo $90 \mathrm{Kg}$ para fêmeas leves, $97 \mathrm{Kg}$ para fêmeas pesadas, $88 \mathrm{Kg}$ para machos leves e $104 \mathrm{Kg}$ para machos pesados.

\subsection{Influência do genótipo, sexo e peso de abate nas características de qualidade de carne}

A Tabela 13 contém as médias das características de qualidade de carne dos tratamentos estudados.

Os dados estatísticos do efeito do genótipo para a Capacidade de Retenção de Água (CRA) e Perda por Exsudação (PE) indicam, claramente, o efeito negativo da presença do gene halotano nos genótipos $\mathrm{Nn}$ e nn nessas características de qualidade de carne avaliadas.

Nesse contexto, o genótipo nn apresentou uma redução na CRA e um aumento na PE comparado com os outros genótipos, atingindo valores correspondentes a carne PSE (pálida, flácida e exsudativa), conforme classificação proposta por Ring \& Kortmann (1988) e Sakata et. al., (1989) para CRA ( $(\mathrm{<}<0,400$ e 0,412) e Kim et. al., (1995) para PE $(8,8 \pm 2,0)$. Os genótipos $\mathrm{NN}_{\mathrm{M}}$ e $\mathrm{NN}_{\mathrm{O}}$ apresentaram valores de CRA correspondentes a carne normal $(0,40<G<0,60)$ e de PE entre carne normal e RSE (róseo - avermelhada, flácida e exsudativa; $\mathrm{PE}=7,2 \pm 0,4)$. Enquanto isso, o genótipo $\mathrm{Nn}$ apresentou valor de CRA correspondente a faixa crítica de carne PSE $(<0,400)$ e de PE $(6,45)$ entre carne normal e RSE $(7,2 \pm 0,4)$, segundo classificação proposta pelos autores citados anteriormente.

Os dados para PE obtidos no presente experimento mostraram que não houve diferença significativa entre os genótipos $N N\left(N_{M}\right.$ e $\left.N N_{O}\right)$ e $N n$. Resultados diferentes foram apresentados por Leach et, al., (1996), que constataram uma PE para os animais NN $(3,4 \%)$ significativamente menor em relação aos suínos $\mathrm{Nn}$ (5,2\%). De Smet et. al., (1996) reportaram que os 
animais homozigotos recessivos (nn) apresentaram maior PE, os heterozigotos $(\mathrm{Nn})$, valor intermediário e os dominantes (NN), o menor valor.

No presente estudo, a PE não diferiu com o peso de abate, onde os valores encontrados para animais leves e pesados são considerados como carne RSE (róseo - avermelhada, flácida e exsudativa) ou PSE (> 5\%) por Warner et. al., (1996), como carne PSE $(8,8 \pm 2,0)$ por Honickel et. al., (1987) e Lopez-Bote \& Warris (1988) e como carne RSE (> 5\%) por Joo et. al., (1995). Sutton et. al., (1997) e Beattie et. al., (1999) também relataram não haver diferença significativa entre os pesos de abate para a PE, sendo encontrados por Sutton et. al., (1997) os valores de 4,55 para animais leves e 4,74 para animais pesados. Beattie et. al., (1999) encontraram os valores 5,88, 6,23, 6,08 e 6,68 para os pesos de 70, 80, 90 e $100 \mathrm{Kg}$, respectivamente.

Em relação à composição da cor ( $\left(\mathrm{L}^{*} \mathrm{a}^{*} \mathrm{~b}^{\star}\right)$ do músculo Longissimus dorsi, o gene halotano presente nos genótipos $\mathrm{Nn}$ e $\mathrm{nn}$ expressou seu efeito negativo no incremento da luminosidade $\left(L^{*}\right)$, contribuindo para uma coloração mais clara, a qual não é desejável sob o ponto de vista de aparência da carne. Houve uma diferença estatística para luminosidade $\left(L^{*}\right)$ e teor de vermelho $\left(a^{*}\right)$ entre os genótipos estudados, sendo que os genótipos $N N\left(N_{M}\right.$ e $\left.N N_{O}\right)$ apresentaram valores de $L^{*}$ e $a^{*}$ significativamente menores do que $\mathrm{Nn}$ e $\mathrm{nn}$. Os valores de luminosidade para os genótipos $\mathrm{Nn}$ e nn correspondem a carne PSE, de acordo com a classificação proposta por Garrido et. al., (1995), quando $L^{*}>49,12$. No entanto, Kim et. al., (1995) e Warner et. al., (1997) consideram valores de $L^{*}=48,1 \pm 0,7$ próximos de carne RSE (róseo - avermelhada, flácida e exsudativa). Considerando ainda os valores de luminosidade $\left(L^{\star}\right)$ para os genótipos $\mathrm{NN}_{\mathrm{M}}$ e $\mathrm{NN}_{O}$, pode-se dizer que estes apresentam uma cor correspondente a carne DFD, conforme classificação sugerida por van der Wal et. al., (1988). Tam et. al., (1997) relataram resultados similares para valor de luminosidade ao encontrado no presente estudo para nn $(51,40)$, porém, estes autores não encontraram diferença significativa para $L^{*}, a^{*}$ e b* entre NN e Nn. Sutton et. al., (1997) e Fernandez et. al., (2002) não encontraram diferenças na 
cor entre os genótipos $N N\left(L^{*}=41,62 ; a^{*}=9,35, b^{*}=6,59\right.$ por Sutton et. al., (1997) e $L^{*}=53,6 ; a^{*}=5,9 ; b^{*}=4,1$ por Fernandez et. al., (2002)) e $\mathrm{Nn}\left(L^{*}=44,77\right.$; $a^{\star}=9,21 ; b^{\star}=6,56$ por Sutton et. al., (1997) e $L^{\star}=54,7 ; a^{\star}=6,3$ e $b^{\star}=3,9$ por Fernandez et. al., (2002)). De Smet et. al., (1996) relataram que os animais nn apresentaram valor significativamente maior para $L^{*}$ que os animais $\mathrm{Nn}(54,7 \mathrm{X}$ 51,0 , respectivamente), sendo que os animais heterozigotos não diferiram significativamente dos animais NN (50,8). Por outro lado, Leach et. al., (1996), reportaram que os suínos carregadores do gene halotano $(\mathrm{Nn})$ apresentaram maiores valores de $L^{*}, a^{*}$ e $b^{*}$ que os animais homozigotos (NN). No presente estudo e nos estudos citados anteriormente, ocorreu uma tendência dos animais $\mathrm{Nn}$ apresentarem uma carne mais pálida que NN.

Os valores de $L^{*}$ e $b^{*}$ foram maiores para os machos, indicando uma carne mais pálida que a das fêmeas, porém, ambos os valores foram considerados como cor de carne normal ( $L^{*}$ entre 43 e 50 ), por Warner et. al., (1996) e Joo et. al., (1995). Resultados similares foram reportados por De Smet et. al., (1996), onde os machos apresentaram valores de 52,6 para $L^{*}$ e 14,3 para $b^{*}$, significativamente maiores que nas fêmeas( 51,8 e 14,1 para $L^{*} e b^{*}$, respectivamente) e por Suzuki et. al., (2003), ( $L^{*}=48,86$ e $b^{*}=5,92 ; L^{*}=47,94$ e $b^{\star}=5,29$, para para machos e fêmeas, respectivamente). Latorre et. al., (2003), Fisher et. al., (2000), Murray et. al., (1989) e Sather et. al., (1991) não encontraram diferença significativa entre os sexos para $L^{*}$ ou $b^{*}$, mas relataram que os machos tiveram carne mais vermelha $\left(a^{*}=4,58\right)$ que as fêmeas $\left(a^{*}=\right.$ 4,02). Suzuki et. al., (2003) encontraram menores valores de $a^{*}(3,08 \times 3,12$ para machos e fêmeas, respectivamente) que no presente estudo, onde não houve diferença estatisticamente significativa entre os sexos.

$\mathrm{O} \mathrm{pH}_{1 h} \mathrm{SC}$ foi maior nos suínos do genótipo $\mathrm{Nn}$ e menor nos do genótipo $\mathrm{NN}_{\mathrm{M}}$. Entretanto, as condições DFD, favorecida por $\mathrm{pH}_{1}>6,4$ (Barton - Gade, 1980) e PSE, por $\mathrm{pH}_{1}<5,8$ (Joo et. al., 1995) não foram observadas no presente estudo. Com relação ao $\mathrm{pH}_{24 h} \mathrm{SM}$, os animais dos genótipos $\mathrm{Nn}$ e $\mathrm{NN}_{\mathrm{M}}$ apresentaram valores significativamente maiores que os outros genótipos, 
enquanto que o menor valor, mostrado pelo genótipo nn, diferiu significativamente dos demais e apresentou-se no limite considerado para carne PSE $\left(\mathrm{pH}_{24 h}<5,5\right)$, segundo Joo et. al., (1995). Fernandez et. al., (2002) não encontraram efeito do genótipo ( $\mathrm{NN}, \mathrm{Nn}$ e nn) no $\mathrm{pH}_{24 h} \mathrm{SM}$. $\mathrm{O}_{\mathrm{pH}} \mathrm{pH}_{24} \mathrm{SC}$, no presente estudo, foi significativamente maior no genótipo $\mathrm{Nn} e$ significativamente menor no genótipo $\mathrm{NN}_{\mathrm{M}}$. No entanto, as diferenças de $\mathrm{pH}_{24 \mathrm{~h}} \mathrm{SC}$ constatadas entre os animais investigados neste experimento correspondem às variações ocorrentes dentro da faixa de $\mathrm{pH}_{24 h}$, classificada como carne que não apresenta as anomalias PSE ou DFD. Dessa forma, todos os genótipos apresentaram valores de $\mathrm{pH}_{24 h} \mathrm{SC}$ dentro da faixa considerada como carne normal $(5,6-5,9)$ por Joo et. al., (1995). Diferente do encontrado no presente estudo, onde os suínos $\mathrm{Nn}$ apresentaram maiores valores de $\mathrm{pH}_{1 \mathrm{~h}} \mathrm{SC}, \mathrm{pH}_{24 h} \mathrm{SM}$ e $\mathrm{pH}_{24 h} \mathrm{SC}$ do que os animais $\mathrm{NN}$ (genótipos $\mathrm{NN}_{\mathrm{M}}$ e $\mathrm{NN}_{\mathrm{O}}$ ), Leach et. al., (1996) encontraram menores valores de $\mathrm{pH}_{1 \mathrm{~h}}$ e $\mathrm{pH}_{24 h}$ para suínos carregadores do gene halotano $(\mathrm{Nn})$, comparados com animais $N N(6,4 \times 6,6$, para $\mathrm{pH}_{1 \mathrm{~h}}$ e 5,6 × 5,7 para $\mathrm{pH}_{24 \mathrm{~h}}$ ). Resultados similares para $\mathrm{pH}_{1 \mathrm{~h}}$ foram encontrados por Jensen e Barton Gade, (1985) e Channon et. al., (2000); Sather et. al., (1991b); Murray et. al., (1992) e Tam et. al., (1997) e para $\mathrm{pH}_{24 h}$, reportados por Pommier e Houde, (1993) e Jones et. al., (1994), quando compararam os genótipos NN e Nn. Entretanto, Klont et. al., $(1993,1994)$ não encontraram diferença significativa no $\mathrm{pH}_{1 \mathrm{~h}}$ entre suínos carregadores e negativos e Lundstrom et. al., (1989), Pommier et. al., (1993), NPPC, (1994) não encontraram diferença entre animais carregadores e negativos para o $\mathrm{pH}_{24 h}$. De Smet et. al., (1996) relataram que o genótipo nn apresentou o menor valor de $\mathrm{pH}_{1 \mathrm{~h}} \mathrm{SM}(5,93), \mathrm{Nn}$, valor intermediário $(6,18)$ e $\mathrm{NN}$, maior valor $(6,30)$, não sendo encontrada esta diferença com relação ao $\mathrm{pH}_{24 h} \mathrm{SM}$. Sutton et. al., (1997) relataram que $0 \mathrm{pH}_{1 \mathrm{~h}}$ e $0 \mathrm{pH}_{24 h}$ não diferiram entre as carcaças $\mathrm{NN}$ e $\mathrm{Nn}$.

$\mathrm{Na}$ maioria dos estudos, as diferenças entre $\mathrm{NN}$ e $\mathrm{Nn}$ dependem das características consideradas. Lundstrom et. al., (1989) não encontraram 
diferenças na cor, mas uma diferença significativa na PE entre animais homozigotos negativos $(N N)$ e heterozigotos $(N n)$. Similarmente, Jensen e Barton-Gade (1985) não encontraram diferenças na cor, porém, quanto aos valores de $\mathrm{pH}_{1}$ e CRA entre $\mathrm{NN}$ e $\mathrm{Nn}$, foram evidentes as diferenças. Sather et. al., (1991c) encontraram diferenças significativas tanto para cor como para PE. Portanto, a herança do alelo $\mathrm{n}$ com relação à qualidade de carne não é absolutamente ou parcialmente recessiva, mas pode variar de acordo com uma característica específica. $\mathrm{Na}$ maioria dos estudos que mencionam similares características de qualidade de carne, uma posição intermediária dos suínos heterozigotos ou uma posição mais próxima dos animais homozigotos dominantes (NN) foi reportada (Sellier, 1987), embora Murray et. al., (1989) concluíram, a partir de seus resultados, que o genótipo Nn mostrou-se mais próximo do genótipo nn para todas as medidas objetivas de qualidade.

No presente estudo, as fêmeas apresentaram maior valor de $\mathrm{pH}_{1 \mathrm{~h}}$ medido no músculo Semispinalis capitis (SC), indicando uma menor velocidade glicolítica nesse músculo em relação aos machos $(6,15$ × 6,03). De acordo com Latorre et. al., (2003), Cisneros et. al., (1996) e Leach et. al., (1996), o sexo não influenciou o $\mathrm{pH}$ da carne. A maioria dos estudos que comparou a qualidade de carne entre machos e fêmeas mostrou haver pouca diferença entre eles (Barton-Gade, 1987 e Ellis et. al., 1996). Beattie et. al., (1999), Channon et. al., (2000) e Cisneros et. al., (1996) relataram não haver efeito estatisticamente significante do sexo para qualquer um dos parâmetros de qualidade de carne avaliados.

Houve um efeito do peso na qualidade de carne para o $\mathrm{pH}_{1 \mathrm{~h}} \mathrm{SC}$, onde os animais pesados tiveram maior valor que os animais leves. Entretanto, não houve efeito para qualquer outra característica de qualidade de carne avaliada. Em outros estudos, o aumento do peso de abate foi associado a reduções na cor e na firmeza do músculo Longissimus thoracis e diminuição do $\mathrm{pH}_{24 \mathrm{~h}}$, maciez e umidade no músculo Longissimus lumborum, sem alteração na $\mathrm{PE}(\%)$ e no conteúdo de gordura (Cisneros et. al., 1996). Martin et. al., (1981) não 
encontraram essas alterações com o aumento do peso de abate entre 73 e 137Kg e Sutton et. al.,(1997) não encontraram efeito do peso no $\mathrm{pH}_{45} \mathrm{e} \mathrm{pH}_{\text {final. }}$

Diante das observações acima, o presente trabalho de pesquisa evidenciou que a qualidade da carne suína foi negativamente afetada pelo genótipo nn nesse estudo. O genótipo nn, que é Pietran puro e homozigoto recessivo (nn), apresentou valores de $\mathrm{pH}_{24 \mathrm{~h}}, \mathrm{~L}{ }^{*} \mathrm{D}$ e PE que o classificam como carne PSE $\left(\mathrm{pH}_{24 h} \mathrm{SM}<5,5\right.$; PE > 8,0\% e $\left.L^{*} \mathrm{D}>50\right)$, por Joo et. al., (1995) Os demais genótipos apresentaram valores para carne normal, sendo que o genótipo $\mathrm{Nn}$ foi inferior ao $\mathrm{NN}\left(\mathrm{NN}_{\mathrm{M}}\right.$ e $\left.\mathrm{NN} \mathrm{N}_{\mathrm{O}}\right)$ somente com relação ao valor de luminosidade $\left(L^{*} D\right)$. A maior incidência de carne PSE em animais homozigotos recessivos comparada com suínos homozigotos dominantes e heterozigotos observada no presente estudo é consistente com as observações de de Smet et. al., (1996), Fisher et. al., (2000) e Fernandez et. al., (2002). Channon et. al., (2000) encontraram uma maior proporção de carne PSE nos suínos Nn, comparado com animais NN (24/38 x 6/37).

Uma rápida queda do $\mathrm{pH}$ após o abate no músculo suíno pode resultar na desnaturação das proteínas miofibrilar e sarcoplasmática, afetando, subseqüentemente, a CRA da carne suína (Bendall \& Wismer-Pederson, 1962). Suínos homozigotos positivos para o gene halotano são, geralmente, mais susceptíveis ao estresse pré-abate, resultando numa maior incidência de carne PSE. A maior incidência de carne PSE observada em suínos nn, comparado com suínos Nn e NN foi suportada pelo aumento da porcentagem de PE e de L* na carne dos animais nn. Joo et. al., (1999) mostraram que a cor pálida e a elevada porcentagem de PE do músculo PSE foram altamente correlacionadas com uma menor concentração de proteína sarcoplasmática solúvel.

Carcaças que apresentam uma taxa normal de glicólise post mortem combinada com altos níveis iniciais de glicogênio podem produzir carne suína com um baixo pH final e elevada perda por exsudação (Bendal \& Swatland, 1988). Esta é, possivelmente, a causa da carne suína RSE. Warner et. al., (1996) propuseram que a alta PE observada na carne suína RSE é causada por 
um baixo pH final, associado à deposição de fosforilase e creatina quinase na miofibrila, não ocorrendo nenhuma transformação na solubilidade protéica ou desnaturação da proteína.

Valores mais altos para o teor de vermelho $\left(a^{*}\right)$ encontrados no genótipo nn no presente estudo, devem-se, provavelmente, à umidade perdida (elevada $\% \mathrm{PE}$ ), aumentando, deste modo, a concentração de pigmento muscular. Os valores de reflectância apresentados no presente estudo estão de acordo com estudos prévios (Fisher et. al., 2000; Leach et. al., 1996; Murray et. al., 1989), confirmando o aumento na dispersão da luz associado com carne PSE, o qual ocorre devido a desnaturação das proteínas sarcoplasmáticas (Fisher et. al., 2000). Os fatores que contribuem para a variação na opacidade da carne crua são a taxa de resfriamento, a taxa de declínio do $\mathrm{pH}$ e a disponibilidade de substrato (glicogênio) para a conversão em ácido lático. Van der Wal et. al., (1987) também indicaram que a cor da carne não é constante ao longo do músculo Longissimus dorsi, onde a parte cranial do músculo é menos susceptível a alterações na qualidade de carne do que a região lombar do músculo.

Conforme observado no presente estudo, a presença do gene halotano está associada com um aumento na reflectância, o qual é percebido por um aumento da palidez do músculo. Apesar de somente $25 \%$ da carne suína ser consumida na forma fresca, transformações negativas na qualidade da carne acabam por aumentar a resistência do consumidor. Embora a indústria brasileira da carne suína esteja consciente dos problemas associados com a carne PSE, não existe, atualmente, nos frigoríficos, um sistema de classificação que permita discriminar as carnes com qualidade inferior. 
Tabela 13. Médias dos tratamentos nas características de qualidade de carne

\begin{tabular}{|c|c|c|c|c|c|c|c|c|c|c|c|c|}
\hline \multirow[b]{2}{*}{ Variável } & \multicolumn{4}{|c|}{ Genótipo } & \multicolumn{2}{|c|}{ Sexo } & \multicolumn{2}{|c|}{ Peso } & \multicolumn{3}{|c|}{ valor $p$} & \multirow[b]{2}{*}{ Interações ${ }^{a}$} \\
\hline & $\mathrm{Nn}$ & $\mathrm{nn}$ & $\mathrm{NN}_{\mathrm{M}}$ & $\mathrm{NN}_{\mathrm{O}}$ & $\mathrm{F}$ & $\mathrm{M}$ & $\mathrm{L}$ & $\mathrm{P}$ & $\mathrm{G}$ & $\mathrm{S}$ & $\mathrm{P}$ & \\
\hline CRA & $0,38 \mathrm{~b}$ & $0,35 \mathrm{~b}$ & $0,46 a$ & $0,39 \mathrm{~b}$ & $0,39 d$ & $0,39 d$ & $0,39 \mathrm{f}$ & $0,40 \mathrm{f}$ & 0,0001 & 0,9561 & 0,4313 & - \\
\hline PE(\%) & $6,45 b$ & $9,48 \mathrm{a}$ & $7,60 \mathrm{~b}$ & $6,64 \mathrm{~b}$ & $7,45 \mathrm{~d}$ & $7,63 \mathrm{~d}$ & $7,35 \mathrm{f}$ & $7,73 \mathrm{f}$ & 0,0001 & 0,5716 & 0,2442 & $G \times P^{*}$ \\
\hline$L * D$ & $49,87 a$ & $51,62 \mathrm{a}$ & $44,09 \mathrm{~b}$ & $44,18 b$ & $46,66 \mathrm{e}$ & $48,21 d$ & $47,89 \mathrm{f}$ & $46,99 \mathrm{f}$ & 0,0001 & 0,0084 & 0,1215 & - \\
\hline$a * D$ & $5,39 \mathrm{~b}$ & $6,22 \mathrm{a}$ & $2,76 \mathrm{c}$ & $2,65 \mathrm{c}$ & $4,17 \mathrm{~d}$ & $4,34 \mathrm{~d}$ & $4,08 \mathrm{f}$ & $4,43 \mathrm{f}$ & 0,0001 & 0,375 & 0,0836 & - \\
\hline$b * D$ & $5,17 \mathrm{a}$ & $5,30 a$ & $5,03 \mathrm{a}$ & $5,66 a$ & $4,75 \mathrm{e}$ & $5,33 d$ & $5,12 \mathrm{f}$ & $4,96 \mathrm{f}$ & 0,2564 & 0,0165 & 0,4966 & - \\
\hline $\mathrm{pH}_{1} \mathrm{SM}$ & $5,86 a$ & $6,03 \mathrm{a}$ & $5,97 \mathrm{a}$ & $5,94 \mathrm{a}$ & $6,00 \mathrm{~d}$ & $5,91 d$ & $5,96 \mathrm{f}$ & $5,94 \mathrm{f}$ & 0,0801 & 0,0567 & 0,687 & - \\
\hline $\mathrm{pH}_{1} \mathrm{SC}$ & $6,22 \mathrm{a}$ & $6,06 \mathrm{~b}$ & $5,99 \mathrm{~b}$ & $6,10 a b$ & $6,15 \mathrm{~d}$ & $6,03 \mathrm{e}$ & $6,04 \mathrm{~g}$ & $6,14 \mathrm{f}$ & 0,0001 & 0,0022 & 0,008 & - \\
\hline $\mathrm{pH}_{24} \mathrm{SM}$ & $5,85 \mathrm{a}$ & $5,57 \mathrm{c}$ & $5,83 a$ & 5,75 b & $5,74 \mathrm{~d}$ & $5,76 d$ & $5,74 \mathrm{f}$ & $5,76 \mathrm{f}$ & 0,0001 & 0,2584 & 0,2507 & SxP* \\
\hline $\mathrm{pH}_{24} \mathrm{SC}$ & $5,98 \mathrm{a}$ & $5,89 \mathrm{~b}$ & $5,76 \mathrm{c}$ & $5,87 \mathrm{~b}$ & $5,86 \mathrm{~d}$ & $5,89 \mathrm{~d}$ & $5,87 \mathrm{f}$ & $5,88 \mathrm{f}$ & 0,0001 & 0,1971 & 0,7893 & $G \times P^{*}$ \\
\hline
\end{tabular}

Nota 1: F: fêmeas; M: machos; L: leves; P: pesados; G: genótipo; S: sexo; P: peso

Nota 2: Médias dentro de uma mesma linha, seguidas de letras diferentes (a-c), são significativamente diferentes para genótipo, no nível de $5 \%$ de significância $(p<0,05)$.

Nota 3: Médias dentro de uma mesma linha, seguidas de letras diferentes (d-e), são significativamente diferentes para sexo, no nível de $5 \%$ de significância $(p<0,05)$.

Nota 4: Médias dentro de uma mesma linha, seguidas de letras diferentes (f-g), são significativamente diferentes para peso, no nível de $5 \%$ de significância $(p<0,05)$.

${ }^{\mathrm{a}} \mathrm{p}<0,05$ 
As interações estatisticamente significativas verificadas no presente estudo, nas características de quantidade de carne, estão apresentadas nas Tabelas 14, 15 e 16.

Não houve evidência de interação estatisticamente significativa entre genótipo e sexo para nenhuma das características estudadas, sugerindo que as diferenças de qualidade de carne entre os quatro genótipos foram mantidas através dos sexos.

Houve interação entre genótipo e peso para PE (Tabela 14) e $\mathrm{pH}_{24} \mathrm{SC}$ (Tabela 15). A perda por exsudação para os animais leves e pesados foi significativamente maior para o genótipo nn $(8,75 \times 10,22)$, verificando que o efeito negativo do gene halotano foi mantido com o aumento do peso de abate. $\mathrm{O} \mathrm{pH}_{24} \mathrm{SC}$ para os animais leves e pesados foi significativamente maior para o genótipo $\mathrm{Nn}(5,96 \times 6,01)$ e menor para o genótipo $\mathrm{NN}_{\mathrm{M}}(5,81 \times 5,72)$, porém, em ambos os casos, os valores correspondem a carne normal, de acordo com Joo et. al., (1995). Leach et. al., (1996) não encontraram evidência de interação entre genótipo e peso de abate para qualquer característica de carne avaliada.

Tabela 14. Médias da interação entre genótipo e peso na perda por exsudação (PE)

\begin{tabular}{ccccccc}
\hline & & \multicolumn{4}{c}{ Genótipo } & \multirow{2}{*}{$\begin{array}{c}\text { Significância } \\
\text { (interação) }\end{array}$} \\
\cline { 2 - 5 } & & $\mathrm{Nn}$ & $\mathrm{nn}$ & $\mathrm{NN}_{\mathrm{M}}$ & $\mathrm{NN}$ & \\
\hline \multirow{2}{*}{ Peso } & $\mathrm{L}$ & $6,84 \mathrm{bc}$ & $8,75 \mathrm{a}$ & $8,13 \mathrm{ab}$ & $5,68 \mathrm{c}$ & $*$ \\
& $\mathrm{P}$ & $6,05 \mathrm{~b}$ & $10,22 \mathrm{a}$ & $7,07 \mathrm{~b}$ & $7,59 \mathrm{~b}$ & $*$ \\
\hline
\end{tabular}

Nota 1: L: leves; P: pesados; * $: p<0,05$

Nota 2: Médias dentro de uma mesma linha, seguidas de letras diferentes (ac) são significativamente diferentes para a interação genótipo x peso, no nível de $5 \%$ de significância $(p<0,05)$ 
Tabela 15. Interação entre genótipo e peso no $\mathrm{pH}_{24} \mathrm{SC}$

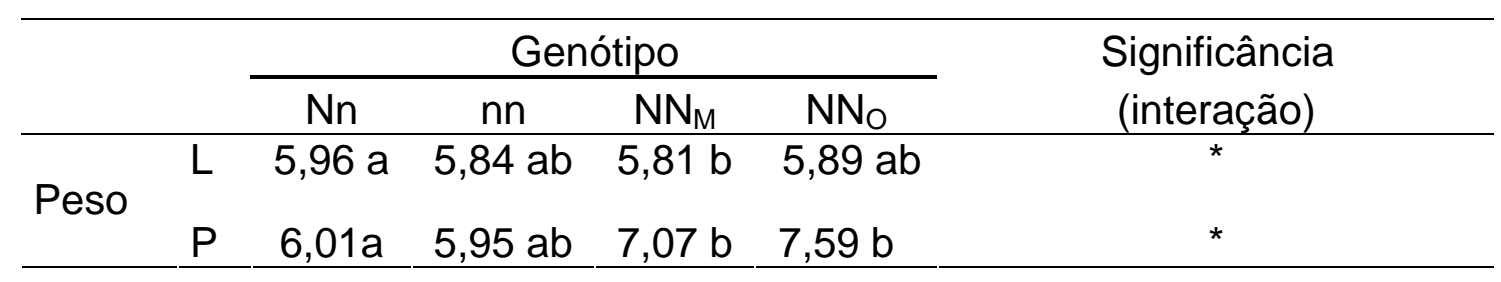

Nota 1: L: leves; P: pesados; * $p<0,05$

Nota 2: Médias dentro de uma mesma linha, seguidas de letras diferentes (ab), são significativamente diferentes para interação genótipo x peso, no nível de $5 \%$ de significância $(p<0,05)$

Houve interação estatisticamente significativa entre sexo e peso para o $\mathrm{pH}_{24} \mathrm{SM}$ (Tabela 16), onde as fêmeas pesadas apresentaram maior valor que as fêmeas leves, ambos os valores considerados normais de acordo com a classificação proposta por Joo et. al., (1995). Beattie et. al., (1999) reportaram não existir interação estatisticamente significante para $\mathrm{pH}_{24}$ ou PE entre sexo e peso.

Tabela 16. Interação entre genótipo e peso no $\mathrm{pH}_{24} \mathrm{SM}$

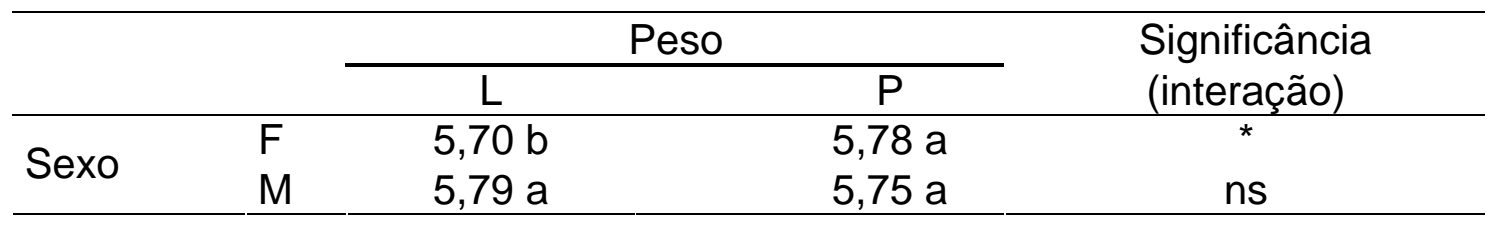

Nota 1: L: leves; P: pesados; * $p<0,05$; ns: não significativo

Nota 2: Médias dentro de uma mesma fileira seguidas de letras diferentes (a-b) são significativamente diferentes para interação sexo x peso, no nível de $5 \%$ de significância $(p<0,05)$ 


\section{CONCLUSÕES}

Esta investigação confirmou que a inclusão do gene halotano em um plantel de suínos resultou em vantagens na musculosidade da carcaça, visto que o genótipo nn obteve maiores valores para AOL e COL e menor PT. No entanto, essa vantagem na obtenção de uma carcaça mais musculosa e com maior quantidade de carne é limitada com relação à qualidade da carne, pois ocorreu maior incidência de carne PSE, conhecida por estar associada a este gene. Uma redução na qualidade de carne pode também resultar em produtos processados de qualidade inferior, como, por exemplo, menor rendimento de produtos curados, resultando, desta forma, numa fonte potencial de perda econômica para o processamento de carne. Além disso, este trabalho mostra que as desvantagens na utilização de animais nn, verificadas na qualidade de carne, são mantidas através do aumento do peso de abate.

A análise comparativa entre os preditores de quantidade de carne obtidos com o auxílio da instrumentação óptica (EG e EM) e a AOL e PT, mostra que ocorreu uma tendência semelhante dos resultados quando o sexo foi considerado, ou seja, as fêmeas apresentaram uma carcaça mais magra que a dos machos. Verificou-se, também, que os machos apresentaram uma carne mais pálida e com maior teor de amarelo que a das fêmeas.

As características da composição carcaça aumentaram com o incremento do peso de abate, fato este, visto como vantajoso, já que os animais pesados apresentaram uma maior musculosidade em relação aos animais leves. Além disso, os resultados desse estudo sugerem que não foram observadas mudanças nos parâmetros de qualidade do músculo com o 
aumento no peso de abate. Por outro lado, constatou-se que o aumento no peso de abate somente incrementou a porcentagem de carne magra nos genótipos $\mathrm{Nn}$ e $\mathrm{NN}_{\mathrm{O}}$. Nos suínos $\mathrm{NN}_{\mathrm{M}}$ e nn, o aumento no peso de abate não favoreceu uma maior deposição de carne magra na carcaça, já que, nesses casos, os animais leves apresentaram os maiores valores para essa característica. Apesar desses resultados, os animais pesados do genótipo nn continuaram apresentando uma maior \%CM que os genótipos $\mathrm{NN}_{\mathrm{O}}$ e $\mathrm{NN}_{\mathrm{M}}$.

Deve-se ressaltar que a quantidade da carne real foi obtida neste experimento através da desossa comercial. Este processo fornece um valor aproximado do conteúdo de carne que o animal depositou na carcaça durante as fases de crescimento e terminação. A realização de um trabalho de dissecação permitiria obter uma quantidade de carne mais próxima da realidade e, nesse sentido, as conclusões refletiriam melhor as possíveis diferenças entre os genótipos avaliados. Deve-se mencionar, ainda, que o investimento no melhoramento genético para o incremento de carne na carcaça é elevado e, nesse contexto, a diferença de $1 \%$ de carne deve ser ressaltada principalmente pelo fato de tornar-se um valor expressivo quando o abate anual de suínos é considerado.

O desafio das empresas de genética está na busca de um animal que possua uma adequada relação entre qualidade e quantidade de carne, pois esse binômio é responsável pelo sucesso econômico da indústria de carne.

Finalmente, a presente investigação sugere que se deva dar uma maior atenção ao abate de animais mais pesados. É importante entender que o peso de abate ideal está relacionado, principalmente, com o mercado atingido e com o custo de produção. Um animal com até $120 \mathrm{Kg}$ resulta em mais cortes, agrega valor a carne e traz rendimentos para o produtor e opções ao consumidor. $O$ principal mito a ser vencido é o de que suíno pesado é sinônimo de gordura. A utilização de rações separadas por sexo, altos níveis de aminoácidos e outras estratégias de manejo têm, certamente, melhorado a conversão do alimento em músculo. Este tipo de tecnologia tem sido amplamente utilizada para aumentar 
a produção de carne suína em uma mesma estrutura, sem a necessidade de investimentos em ampliação de rebanho ou instalações. 


\section{REFERÊNCIAS BIBLIOGRÁFICAS}

AALHUS, J.L.; JONES, S.D.M.; ROBERTSON, W.M.; TONG, A.K.; SATHER, A.P. Growth characteristics and carcass composition of pigs with known genotypes for stress susceptibility over a weight range of 70 to 120 Kg. Animal Production, v.52, p.347-353, 1991.

AASLYNG, M.D.; BARTON-GADE, P. Low stress pre-slaughter handling: effect of lairage time on the meat quality of pork. Meat Science, v.57, p.87-92, 2001.

ADAM, J.L.; SMITH, W.C. The use of sample joints in predicting the composition of pig carcass. Animal Production, v.8, p.85-94, 1966.

ADEOLA, O.; BALL, R.O. Hypothalamic neurotransmitter concentrations and meat quality in stressed pigs offered excess dietary tryptophan and tyrosine. Journal of Animal Science, v.70, p.1888-1892, 1992.

ALLEN, C.E.; FOEGEDING, E.A. Some lipid characteristics and interactions in muscle foods: a review. Food Technology, v.35, p.253-257, 1981. 
ANDERSEN, H.J. What is pork quality? In: ANNUAL MEETING OF THE EUROPEAN ASSOCIATION FOR ANIMAL PRODUCTION, 50., Zurich, 1999. Proceedings. Zurich: CAB International, 1999. p.15-28.

ANDERSSON, L. Genetic dissection of phenotypic diversity in farm animals. Nature Review. Genetics, v.2, p.130-138, 2001.

APPLE, J.K.; MAXWELL, C.V.; DERODAS, B.; WATSON, H.B.; JOHNSON, Z. $B$. Effect of magnesium mica on performance and carcass quality of growingfinishing swine. Journal of Animal Science, v.78, p.2135-2143, 2000.

APPLE, J.K.; MAXWELL, C.V.; STIVARIUS, M.R.; RAKES, L.K.; JOHNSON, Z.B. Effects of dietary magnesium and halothane genotype on performance and carcass traits of growing-finishing swine. Livestock Production Science, v.76, n.1-2, p.103-113, 2002.

ASGHAR, A.; GRAY, J.I.; BOOREN, A.M.; GOMAA, E.A.; ABOUZIED, M.M.; MILLER, E.R.; BUCKLEY, D.J. Influence of supranutritional dietary vitamin E levels on subcellular deposition of alpha-tocopherol in the muscle and on pork quality. Journal of the Science of Food and Agriculture, v.57, p.3141, 1991.

AUGUSTINI, C. Ursachen unerwünschter. Fleischbeschaffenheit, v.3, p.165186, 1982. 
BARTON-GADE, P. Further investigations into relationships between measurements carried out on the slaughter line and pig meat quality the day after slaughter. In: EUROPEAN MEETING OF MEAT RESEARCH WORKERS, 26., Colorado Springs, 1980. Proceedings. Colorado Springs: s. ed., 1980. v.1, p.50-53.

BARTON-GADE, P. Meat and fat quality in boars, castrates, and gilts. Livestock Production Science, v.16, p.187, 1987.

BARTON-GADE, P. Live handling, stunning and slaughter of red meat species. Rolskilde: Danish Meat Research Institute, 1993. p.43-58. (Internal report)

BARTON-GADE, P.A. Developments in the pre-slaughter treatment of slaughter animals. In: EUROPEAN MEETING MEAT RESEARCH WORKERS, Madrid, 1985. Proceedings. Madrid: MSC, 1985. p.31-39.

BARTON-GADE, P. Danish experience in meat quality improvement. In: WORLD CONGRESS ON GENETICS APPLIED TO LIVESTOCK PRODUCTION, 4., Edinburgh, 1990. Proceedings. Edinburgh: CAB Interantional, 1990. p.511-520.

BARTON-GADE, P. The effect of pre-slaugther handling on meat quality of pigs. In: CRANWELL, P.D. (Ed.). Manupulating pig production. Melbourne: Frankland, 1997. cap.6, p.100-123. 
BASTOS, R.G.; FEDERIZZI, J.; DESCHAMPS, J.C.; CARDELLINO, R.A.; DELLAGOSTIN, O.A. Efeito do gene do estresse suino sobre caracteristicas de quantidade e qualidade de carcaça. Revista Brasileira de Zootecnia, v.30, n.1, p.37-40, 2001.

BEATTIE, V.E.; WEATHERUP, R.N.; MOSS, B.W.; WALKER, N. The effect of increasing carcass weight of finishing boars and gilts on joint composition and meat quality. Meat Science, v.52, p.205-211, 1999.

BEE, G. Muscle glycogen and lactate content and pork quality traits as affected by available dietary carbohydrate in pigs. Journal of Animal Science, v.79, p.19, 2001. Supplement 1.

BENDALL, J.R.; WISMER-PEDERSEN, J. Some properties of the fibrillar proteins of normal and watery pork muscle. Journal of Food Science, v.27, p.144-158, 1962.

BENDALL, J.R. Post mortem changes in muscle. In: Bourne, G.H. (Ed.). Structure and function of muscle. Newcastle: STA, 1973. v.2, p.243-309.

BENDALL, J.R.; SWATLAND, H.J. A review of the relationships of $\mathrm{pH}$ with physical aspects of pork quality. Meat Science, v.24, p.85-126, 1988.

BERG, E.P.; ALLEE, G.L. Creatine monohydrate supplemented in swin finishing diets and fresh pork quality. I. A controlled laboratory experiment. Journal of Animal Science, v.79, p.3075-3080, 2001. 
BERG, E.P.; MCFADIN, E.L.; MADDOCK, K.R.; GOODWIN, R.N.; BAAS, T.J.; KEISLER, D.H. Serum concentrations of leptin in six genetic lines of swine and relationship with growth and carcass characteristics. Journal of Animal Science, v.81, p.167-171, 2003.

BERTRAM, H.C.; PETERSEN, J.S.; ANDERSEN, H.J. Relationship between $\mathrm{RN}^{-}$genotype and drip loss in meat from Danish pigs. Meat Science, v.56, p.49-55, 2000.

BERTRAM, H.C.; DONSTRUP, S.; KARLSSON, A.H.; ANDERSEN, H.J.; STODKILD-JOGERSEN, H. Post mortem energy metabolism and pH development in porcine $\mathrm{M}$. Iongissimus dorsi as affected by two diferents cooling regimes. A ${ }^{31} \mathrm{P}-\mathrm{NMR}$ spectroscopic study. Magnetic Resonance Imaging, v.9, p.993-1000, 2001.

BLANCHARD, P.J.; WARKUP, C.C.; ELLIS, M.; WILLIS, M.B.; AVERY, P. The influence of the proportion of Duroc genes on growth, carcass and pork esting quality characteristics. Animal Science, v.68, p.495-501, 1999.

BOHAC, C.E.; RHEE, K. Influence of animal diet and muscle location on cholesterol content of beef and pork muscles. Meat Science, v.23, p.71, 1988.

BORCHERT, L.L.; BRISKEY, E.J. Prevention of pale, soft, exudative porcine muscle through partial freezing with liquid nitrogen post-mortem. Journal of Food Science, v.29, p.203-209, 1964. 
BRISKEY, E.J. Etiological status and associated studies of pale, soft, exsudative porcine musculature. Advances in Food Research, v.13, p.89-178, 1964.

BRISKEY, E.J.; BRAY, R.W.; HOEKSTRA, W.G.; PHILLIPS, P.H.; GRUMMER, R.H. The effect of exhaustive exercise and high sucrose regimen on certain chemical and physical pork ham muscle characteristics. Journal of Animal Science, v.18, p.173-177, 1959.

BRISKEY, E.J.; BRAY, R.W.; HOEKSTRA, W.G.; PHILLIPS, P.H.; GRUMMER, R.H. Effect of high protein, high fat and high sucrose rations on the water binding and associated properties of pork muscle. Journal of Animal Science, v.19, p.404-411, 1960.

BOWKER, B.C.; WYNVEEN, E.J.; GRANT, A.L.; GERRARD, D.E. Effects of electrical stimulation on early post mortem muscle $\mathrm{pH}$ and temperature declines in pigs from different genetic lines and halothane genotypes. Meat Science, v.53, p.125-133, 1999.

BUCKLEY, D.J.; MORRISSEY, P.A.; GRAY, J.I. Influence of dietary vitamin E on the oxidative stability and quality of pig meat. Journal of Animal Science, v.73, p.3122-3130, 1995.

BUEGE, D.R.; HENDERSON, D.W.; WATTERS, S.H.; BOERCHERT, L.L.; HENTGES, E.J. A nationwide audit of the composition of pork and poultry cuts and retails of Wisconsin - Madison. Journal of Animal Science, v.75, p.7, 1997. Supplement 1. 
CAMERON, N.D.; WARRIS, P.D.; PORTER, S.J.; ENSER, M.B. Comparision of Duroc and British Landrace pigs for meat and eating quality. Liverstock Production Science, v.26, p.119-135, 1990.

CAMERON, N.D.; ENSER, M.; NUTE, G.R.; WHITTNGTON, F.M.; PENMANN, J.C.; FISKEN, A.C.; PERRY, A.M.; WOOD, J.D. Genotype with nutrition interaction on fatty acid composition of intramuscular fat and the relationship with flavour of pig meat. Meat Science, v.55, p.187-195, 2000.

CAMERON, N.D.; PENMAN, J.C.; FISKEN, A.C.; NUTE, G.R.; PERRY, A.M.; WOOD, J.D. Genotype with nutrition interactions for carcass composition and meat quality in pig genotypes selected for components of efficient lean growth rate. Animal Science, v.69, p.69-80, 1999.

CAMPBELL, R.G.; TAVERNER, M.R. Genotype and sex effects on the relationship between energy intake and protein deposition in growing pigs. Journal of Animal Science, v.66, p.676, 1988.

CANDEK-POTOKAR, M.; ZLENDER, B.; BONNEAU, M. Effects of breed and slaughter weight on longissimus muscle biochemical traits and sensory quality in pigs. Annales de Zootechnie, v.47, p.3-16, 1998.

CANDEK-POTOKAR, M.; MONIN, G.; ZLENDER, B. Pork quality, processing, and sensory characteristics of dry-cured hams as influenced by Duroc crossing and sex. Journal of Animal Science, v.80, p.988-996, 2002. 
CANNON, J.E.; MORGAN, J.B.; SCHMIDT, G.R.; TATUM, J.D.; SOFOS, J.N.; SMITH, G.C.; DELMORE, R.J.; WILLIAMS, S.N. Growth and fresh meat quality characteristics of pigs supplemented with vitamin $E$. Journal of Animal Science, v.74, p.98-105, 1996.

CARROLL, A.L.; EGGERT, J.M.; SCHINCKEL, A.P.; RICHERT, B.T. Effects of high oil corn and duration of conjugated linoleic acid (CLA) supplementation on pig growth, pork quality and carcasss composition. Purdue Swine Day, 1999. http://www.ansc.Purdue.Edu/swine/swineday99/psd06-99.htm (27 July 2004)

CASTEELS, M.J.; VAN OECKEL, M.J.; BOSCHAERTS, G.; SPINCEMAILLE, G.; BOUCQUÉ, C.V. The relationship between carcass, meat and eating quality of three pig genotypes. Meat Science, v.40, p.253-269, 1995.

CHANNON, H.A.; PAYNE, A.M.; WARNER, R.D. Halothane genotype, preslaughter handling and stunning method all influence pork quality. Meat Science, v.56, p.291-299, 2000.

CHANNON, H.A.; PAYNE, A.M.; WARNER, R.D. Comparision of CO2 stunning with manual electrical stunning $(50 \mathrm{~Hz})$ of pigs on carcass and meat quality. Meat Science, v.60, p.63-68, 2002.

CHEAH, K.S.; CHEAH, A.M.; KRAUSGRILL, D.I. Effect of dietary supplementation of vitamin E on pig meat quality. Meat Science, v.39, p.255-264, 1995. 
CHIBA, L.I.; KUHLERS, D.L.; FROBISH, L.T.; JUNGST, S.B.; HUFF, E.J.; LONERGAN, S.M.; CUMMINS, K.A. Effect of dietary restrictions on growth performance and carcass quality of pigs selected for lean growth efficiency. Livestock Production Science, v.74, p.93-102, 2002.

CHRISTIAN, L.L. A review of the role of genetics in animal stress susceptibility and meat quality. In: PORK QUALITY SYMPOSIUM, Wiscosin, 1972. Proceedings. Wiscosin: University Wiscosin, 1972. p.91-115.

CISNEROS, F.; ELLIS, M.; MCKEITH, F.K.; MCGRAW, J.; HYUN, Y. Influence of slaughter weight on carcass cutting yields and meat quality in pigs. Journal of Animal Science, v.72, p.378, 1994. Supplement 1.

CISNEROS, F.; ELLIS, M.; MCKEITH, F.K.; MCGRAW, J.; FERNANDO, R.L. Influence of slaughter weight on growth and carcass characteristics, commercial cutting and curing yields, and meat quality of barrows and gilts from two genotypes. Journal of Animal Science, v.74, p.925-933, 1996.

COOK, M.E.; JEROME, D.L.; CRENSHAW, T.D.; BUEGE, D.R.; PARIZA, M.W.; ALBRIGHT, K.J.; SCHMIDT, S.P.; SCIMECA, J.A.; LOFGREN, P.A.; HENTGES, E.J. Feeding conjugated linoleic acid improves feed efficiency and reduces carcass fat in pigs. Experimental Biology, v.98, p.836, 1998.

COSTA, L.N.; FIEGO, D.P.; DALL'OLIO, S.; DAVOLI, R.; RUSSO, V.; FIEGO, D.P. Combined effects of pre-slaughter treatments and lairage time on carcass and meat quality in pigs of different halothane genotype. Meat Science, v.61, p.41-47, 2002. 
CROMWELL, G.L.; CLINE, T.R.; CRENSHAW, J.D.; CRENSHAW, T.D.; EWAN, R.C.; HAMILTON, C.R.; LEWIS, A.J.; MAHAN, D.C.; MILLER, E.R.; PETTIGREW, J.E.; TRIBBLE, L.F.; VEUM, T.L.; The dietary protein and (or) lysine requeriments of barrows and gilts. Journal of Animal Science, v.71, p.1510-1519, 1993.

CULAU, P.D.O.; LOPEZ, J.; RUBENSAM, J.M.; LOPES, R.F.F.; NICOLAIEWSKY, S. Influencia do gene halotano sobre a qualidade da carne suina. Revista Brasileira de Zootecnia, v.31, p.954-961, 2002.

DE SMET, S.M.; PAUWELS, H.; DE BIE, S.; DEMEYER, D.I.; CALLEWIER, J.; EECKHOUT, W. Effect of halothane genotype, breed, feed withdrawal, and lairage on pork quality of Belgian slaughter pigs. Journal of Animal Science, v.74, p.1854-1863, 1996.

DEVOL, D.L.; McKEITH, F.K.; BECHTEL, P.J.; NOVAKOFSKI, J.; SHANKS, R.D.; CARR, T.R. Variation in composition and palatability traits and relationships between muscle characteristics and palatability in a random sample of pork carcasses. Journal of Animal Science, v.66, p.385-395, 1988.

DE VRIES, A.G.; VAN DER WAL, P.G.; LONG, T.; EIKELENBOOM, G.; MERKS, J.W.M. Genetic parametres of pork quality and production traits in Yorkshire populations. Livestock Production Science, v.40, p.277-289, 1994. 
DENG, Y.; ROSENVOLD, K.; KARLSSON, A.H.; HORN, P.; HEDEGAARD, J.; STEFFENSEN, C.L.; ANDERSEN, H.J. Relationship between thermal denaturation of porcine muscle proteins and water holding capacity. Journal of Food Science, v.67, p.1642-1647, 2002.

DRANSFIELD, E.; LEDWITH, M.J.; TAYLOR, A.A. Effect of electrical stimulation, hip suspension and ageing in chilled pig meat. Meat Science, v.29, p.129-139, 1991.

D'SOUZA, D.N.; MULLAN, B.P. The effect of genotype, sex and management strategy on the eating quality of pork. Meat Science, v.60, p.95-101, 2002.

D'SOUZA, D.N.; WARNER, R.D.; LEURY, B.J.; DUNSHEA, F.R. The effect of dietary magnesium aspartate supplementation on pork quality. Meat Science, v.76, p.104-109, 1998.

DUGAN, M.E.R.; AALHUS, J.L.; JEREMIAH, L.E.; KRAMER, J.K.G.; SCHAEFER, A.L. The efects of feeding conjugated linoleic acid on subsequent pork quality. Canadian Journal of Animal Science, v.77, p.4551, 1999.

DUNSHEA, F.R. Nutrient requirements of pigs treated with metabolic modifiers. In: NUTRITION SOCIETY OF AUSTRALIA ANNUAL SCIENTIFIC MEETING, Newcastle, 1994. Proceedings. Newcastle: STA, 1994. p.102113. 
DUNSHEA, F.R.; OSTROWSKA, E. Conjugated linoleic acid: snake oil or wonder fat? In: RECENT ADVANCES IN ANIMAL NUTRITION IN AUSTRALIA, 12., Armidale, 1999. Proceedings. Armidale: New England Publishers, 1999. p.159-166.

DUNSHEA, F.R.; OSTROWSKA, E.; MURALITHARAN, M.; CROSS, R.; BAUMAN, D.E.; PARIZA, M.W.; SKARIE, C. Dietary conjugated linoleic acid decreases backfat in growing gilts. Journal of Animal Science, v.76, p.131, 1998.

DUNSHEA, F.R.; OSTROWSKA, E.; LUXFORD, B.; SMITS, R.J.; CAMPBELL, R.G.; D'SOUZA, D.N.; MULLAN, B.P. Dietary conjugated linoleic acid can decrease backfat in pigs housed under commercial conditions. Asian Australasian Journal of Animal Sciences, v.15, p.1011-1017, 2002.

EDWARDS, S.A.; WOOD, J.D.; MONCRIEFF, C.B.; PORTER, S.J. Comparision of the Duroc and Large White as terminal sire breeds and their effect on pig meat quality. Animal Production, v.54, p.289-297, 1992.

EGGERT, J.M.; SHEISS, E.B.; SCHINCKEL, A.P.; FORREST, J.C.; GRANT, A.L.; MILLS, S.E.; WATKINS, B.A. Effects of genotype, sex, slaughter weight and dietary fat on pig growth, carcass composition and pork quality. Purdue Swine Day, 1996. http://www.ansc.purdue.edu/swine/swineday/sday96/psd12-96.htm (26 April 2004) 
EGGERT, J.M.; FARRAND, E.J.; SCHINCKEL, A.P.; MILLS, S.E. The effects of genotype on fat deposition and carcass quality. Purdue Swine Day, 1997. http://www.ansc.purdue.edu/swine/swineday/sday97/psd82-84.htm (26 April 2004)

EIKELENBOOM, G.; MINKEMA, D. Prediction of pale, soft, exsudative muscle with a non-lethal test for the halotane-induced porcine malignant hyperthermia syndrome. Tijdschrift voor Diergeneeskunde, v.99, p.421426, 1974.

EIKELENBOOM, G.; BOLINK, A.H.; SYSBESMA, W. Effect of fasting before delivery on pork quality and carcass yield. In: INTERNATIONAL CONGRESS OF MEAT SCIENCE AND TECHNOLOGY, 37., Copenhagen, 1989. Proceedings. Copenhagen: s. ed., 1989. v.3, p.999-1005.

EIKELENBOOM, G.; BOLINK, A.H.; SYSBESMA, W. Effect of feed withdrawal before delivery on pork quality and carcass yield. Meat Science, v.29, p.2520, 1991.

EKSTROM, K.E. Genetic and sex considerations in swine nutrition. In: MILLER, E.R.; ULLREY, D.E.; LEWIS, A.J. (Ed.). Swine nutrition. Stonehan: British Library, 1991. p.415-424.

ELLIS, M.; WEBB, A.J.; AVERY, P.J.; BROWN, I. The influence of terminal sire genotype, sex, slaughter weight, feeding regime and slaughter-house on growth performance and carcass and meat quality in pigs and on the organoleptic qulities of fresh pork. Animal Science, v.62, p.521-530, 1996. 
ELLIS, M.; HORSFIELD, S.V.K. The potential for increasing slaughter weights for bacon pigs in the United Kingdom. Pig News and Information, v.9, p.3134, 1998.

ENDER, K.; NUERNBERG, K.; REHFELDT, C. Meat quality traits affected by the use of porcine somatotrophin (STs). In: INTERNATIONAL CONGRESS OF MEAT SCIENCE AND TECHNOLOGY, 38., Clermont-Ferrand, 1992. Proceedings. Clermont-Ferrand: Francis, 1992. p.37-40.

ENFÄLT, A.C.; LUNDSTRÖM, K.; HANSSON, I.; JOHANSEN, S.; NYSTRÖM, P.E. Comparision of non-carriers and heterozygous carriers of $\mathrm{RN}^{-}$allele for carcass composition, muscle distribuition and technological meat quality in Hampshire-sired pigs. Livestock Production Science, v.47, p.221-229, 1997a.

ENFÄLT, A.C.; LUNDSTRÖM, K.; HANSSON, I. Estimated frequency of the RN ${ }^{-}$ allele in Swedish Hampshire pigs and comparison of glycolytic potencial, carcass composition, and technological meat quality among Swedish Hampshire, Landrace, and Yorkshire pigs. Journal of Animal Science, v.75, p.2924-2935, 1997b.

ENGESETH, K.O.L.; BERGEN, W.G.; HELFERICH, W.G.; KNUDSON, B.K.; MERKEL, R.A. Fatty acid profiles of lipid depots and cholesterol concentration in muscle tissue of finishing pigs ractopamine. Journal of Food Science, v.57, p.1060-1062, 1992.

ESTRADE, M.; VIGNON, X.; MONIN, G. Effect of the $\mathrm{RN}^{-}$gene on ultrastucture and protein fractions in pig muscle. Meat Science, v.35, p.313-319, 1993. 
FAUCITANO, L. Causes of skin damage to pig carcasses. Canadian Journal of Animal Science, v.81, p.39-45, 2001.

FAUSTMAN, C.; CASSENS, R.G. The biochemical basis for discoloration in fresh meat: a review. Journal of Muscle Foods, v.1, p.217-243, 1990.

FELÍCIO, P.E; CORTE, O.O.; FÁVERO, J.A.; FREITAS, A.R. Equações de predição da porcentagem de carne magra em carcaças suínas. Ciência e Tecnologia de Alimentos, v.6, n.1, p.17-30, 1986.

FERNANDES, T.H.; SMITH, W.C.; ARMSTRONG, D.G. The administration of sugar solutions to pigs immediately prior to slaughter. I. Effect on carcass yield and some muscle and liver characteristics. Animal Production, v.29, p.213-221, 1979.

FERNANDEZ, X.; NEYRAUD, E.; ASTRUC, T.; SANTE, V. Effects of halothane genotype and pre-slaughter treatment on pig meat quality. Part I. Post mortem metabolism, meat quality indicators and sensory traits of $\mathrm{m}$. Longissimus lumborum. Meat Science, v.62, p.429-437, 2002.

FERNANDEZ, X.; TORNBERG, E.; MAGARD, M.; GORANSSON, L. Effect of feeding a high level of sugar in the diet for the last 12 days before slaughter on muscle glycolytic potencial and meat quality traits in pigs. Journal of the Science and Food Agriculture, v.60, p.135-138, 1992.

FERNANDEZ, X.; MEUNIER-SALAUN, M.C.; ECOLAN, P.; MORMED, P. Interactive effect of food deprivation and agonistic behavior on blood parameters and muscle glycogen in pigs. Physiology and Behavior, v.58, p.337-345, 1995. 
FERNANDEZ, X.; MONIN, G.; TALMANT, A.; MOUROT, J.; LEBRET, B. Influence of intramuscular fat contento $\mathrm{n}$ the quality of pig meat. I. Composition of the lipid fraction and sensory characteristics of $\mathrm{m}$. Longissimus lumborum. Meat Science, v.53, p.59-65, 1999.

FISCHER, K. Quallitätsabweichungen bei Rindfleisch. Kulmbacher Reihe Band, v.7, p.235-268, 1987.

FISHER, P. Carcass and meat quality characteistics of three halothane genotypes in pigs. Republic of South Africa, 1995. 170p. Thesis (M.S) University of Stellenbosch.

FISHER, P.; MELLETT, F.D.; HOFFMAN, L.C. Halothane genotype and pork quality. 1. Carcass and meat quality characteistics of three halothane genotypes. Meat Science, v.54, p.9-105, 2000.

FORTIN, A. The effect of slaughter weight on the carcass characteristics of Yorkshire barrows and gilts. Canadian Journal of Animal Science, v.60, p.265, 1980.

FOUILLAUX, M.N.; LE ROY, P.; GRUSAND, J.; RENARD, C.; SELLIER, P.; BONNEAU, M. Support for single major genes influencing fat androstenone level and development of bulbo-urethral glands in young boars. Genetics Selection Evolution, v.29, p.357-366, 1997.

FRANK, J.W.; RICHERT, B.T.; SCHINCKEL, A.P.; BELSTRA, B.A.; ELLIS, M.; $\begin{array}{lllll}\text { GRANT, A.L. } & \text { Purdue } & \text { Swine } & \text { Day, } & \end{array}$ http://www.ansc.purdue.edu/swine/swineday/sday97/psd13-22.htm. (26 April 2004) 
FRIESEN, K.G.; NELSSEN, J.L.; UNRUH, J.A.; GOODBAND, R.D.; TOKACH, M.D. Effects of the interrelationship between genotype, sex, dietary lysine on growth performance and carcass composition in finishing pigs fed either 104 or 127 Kilograms. Journal of Animal Science, v.72, p.946-954, 1994.

FUJII, J.; OTSU, K.; ZORZATO, F.; DE LEON, S.; KHANNA, V.K.; WEILER, J.E.; O'BRIEN, P.J.; MACLENNAN, D.H. Identification of a mutation in porcine ryanodine receptor associated with malignant hypertermia. Science, v.253, p.448-451, 1991.

FULLER, M.F.; FRANKLIN, M.F.; MCWILLIAM, R.; PENNIE, K. The responses of growing pigs, of diferents sex and genotype, to dietary energy and protein. Animal Science, v.60, p.291-298, 1995.

GARCÍA-MACÍAS, J.A.; GISPERT, M.; OLIVER, M.A.; DIESTRE, A.; ALONSO, P.; MUÑOZ-LUNA, A.; SIGGENS, K.; CUTHBERT-HEAVANS, D. The effects of cross, slaughter weight and halothane genotype on leanness and meat and fat quality in pig carcasses. Animal Science, v.63, p.487-496, 1996.

GARNIER, J.P.; KLONT, R.; PLASTOW, G. The potential impact of current animal research on the meat industry and consumer attitudes towards meat. Meat Science, v.64, p.219-237, 2003.

GARRIDO, D.; PEREZ, A.; SANCHEZ-FERRER, A. Meat pigment determination by phase partitioning in Triton X-114 and oxidation with sodium nitrite. Journal of Science Food and Agriculture, v.64, p.327-329, 1995.

GIGIEL, A.; BUTLER, F.; HUDSON, B. Alternative methods of pig chilling. Meat Science, v.26, p.67-83, 1989. 
GONZALEZ, J.; SOLER, J.; GISPERT, M.; PUIGVERT, X.; TIBAU, J. Composicion quimica de la canal porcina: efecto del peso, sexo y genotipo. In: JORNADAS SOBRE PRODUCCION ANIMAL, 9., Zaragoza, 2001. Proceedings. Zaragoza: s. ed., 2001. p.661-663.

GREGORY, N.G. Preslaughter handling, stunning and slaughter. Meat Science, v.36, p.45-56, 1994.

GREGORY, N.G.; GRANDIN, T. Animal welfare and meat science. London: CAB International, 1998. 286p.

GU, Y.; SCHINCKEL, A.P.; MARTIN, T.G. Growth, development, and carcass composition in five genotypes of swine. Journal of Animal Science, v.70, p.1719-1729, 1992.

GUISE, H.J.; PENNY, R.H. Factors influencing the welfare and carcass and meat quality of pigs. 2. Mixing unfamiliar pigs. Animal Production, v.49, p.511-515, 1989.

HAMILTON, D.N.; ELLIS, M.; MILLER, K.D.; MCKEITH, F.K.; PARRETT, D.F. The effect of the Halothane and Rendement Napole genes on carcass and meat quality characteristics of pigs. Journal of Animal Science, v.78, p.2862-2867, 2000.

HAMM, R. Biochemistry of meat hydration. Advances in Food Research, v.10, p.355, 1960. 
HASTY, J.L.; VAN-HEUGTEN, E.; SEE, M.T.; LARICK, D.K. Effect of vitamin E on improving fresh pork quality in Berkshire and Hampshire sired pigs. Journal of Animal Science, v.80, p.3230-3237, 2002.

HENCKEL, P.; KARLSSON, A.H.; JENSEN, M.T.; OKSBJERG, N.; PETERSEN, J.S. Metabolic conditions in porcine longissimus muscle immediately pre-slaughter and its influence on peri and post mortem energy metabolism. Meat Science, v.62, p.145-155, 2002.

HERFORT PEDERSEN, P.; OKSBJERG, N.; KARLSSON, A.H.; BUSK, H.; BENDIXEN, E.; HENCKEL, P. A within litter comparision of muscle fibre characteristics and growth of Halothane carriers and halothane free crossbreed pigs. Livestock Production Science, v.73, p.15-24, 2001.

HERTZMAN, C.; GÖRANSSON, L.; RUDÉRUS, H. Influence of fishmeal, rapeseed, and rape-seed meal in feed at the fatty acid composition and storage stability of porcine body fat. Meat Science, v.23, p.37-53, 1988.

HONIKEL, K.O. The water binding of meat. Fleischwirtschaft, v.67, p.418-452, 1987.

HONIKEL, K.O.; KIM, C.J. Causes of the development of PSE pork. Fleischwirts, v.66, p.349-353, 1986.

HOVENIER, R.; KANIS, E.; ASSELDONK, T.; WESTERINK, N.G. Genetic parameters of pig meat quality traits in a halothane negative population. Livestock Production Science, v.32, p.309-321, 1992. 
HUFF-LONERGAN, E.; BASS, T.J.; MALEK, M.; DEKKERS, J.C.M.; PRUSA, K.; ROTHSCHILD, M.F. Correlations among selected pork quality traits. Journal of Animal Science, v.80, p.617-627, 2002.

IRVING, T.C.; SWATLAND, H.J.; MILLMAN, B.M. Journal of Animal Science, v.67, p.152, 1989.

JAKOBSEN, K. Dietary modifications of animal fats: status and future perspectives. European Journal of Lipid Science and Technology, v.101, p.475-483, 1999.

JANSS, L.L.; VAN ARENDONK, J.A.; BRASCAMP, E.W. Bayesian statistical analyses for presence of single genes affecting meat quality traits in a crossed pig population. Genetics, v.145, p.395-408, 1997.

JENSEN, P.; BARTON-GADE, P.A. Performance and carcass characteristics of pigs with known genotypes for halothane susceptibility. In: COMMISSION ON ANIMAL MANAGEMENT AND HEALTH AND COMMISSION OF PIG PRODUCTION, Wageningen, 1985. Proceedings. Wageningen: s. ed., 1985. p.80-93.

JONES, S.D.M.; MURRAY, A.C.; SATHER, A.P.; ROBERTSON, W.M. Body proportions and carcass composition of pigs with known genotypes for stress susceptibility fasted for different periods of time prior to slaughter. Canadian Journal of Animal Science, v.68, p.139, 1988.

JONES, S.D.M.; JEREMIAH, L.E.; ROBERTSON, W.M. The effects of spray and blast-chilling on carcass shrinkage and pork muscle quality. Meat Science, v.34, p.351-362, 1993. 
JONES, S.D.M.; CLIPLEF, R.L.; FORTIN, A.F.; MCKAY, R.M.; MURRAY, A.C.; POMMIER, S.A.; SATHER, A.P.; SCHAEFER, A.L. Production and antemortem factors influencing pork quality. Pig News Information, v.15, n.1, p.15, 1994.

JOO, S.T.; KAUFFMAN, R.G.; KIM, B.C.; KIM, C.J. The relationship between color and water holding capacity in postrigor porcine Longissimus muscle. Journal of Muscle Foods, v.6, p.211-226, 1995.

JOO, S.T.; KAUFFMAN, R.G.; KIM, B.C.; PARK, G.B. The relationship of sarcoplasmatic and myofibrillar protein solubility to colour and water holding capacity in porcine longissimus muscle. Meat Science, v.52, p.291-297, 1999.

JOO, S.T.; LEE, J.I.; HA, Y.L.; PARK, G.B. Effects of dietary conjugated linoleic acid on fatty acid composition, lipid oxidation, colour, and water holding capacity of pork loin. Journal of animal science, v.80, p.108-112, 2002.

JOSELL, A.; MARTINSSON, L.; BORGGAARD, C.; ANDERSEN, J.R.; TORNBERG, E. Determination of $\mathrm{RN}^{-}$phenotype in pigs at slaughter-line using visual and near-infrared spectroscopy. Meat Science, v.55, p.273-278, 2000.

KANIS, E.; NIEUWHOF, G.J.; DE GREEF, K.H.; VAN DER HEL, W.; VESTERGEN, M.W.A.; HUISMAN, J.; VAN DER WAL, P. Effect of recombinant porcine somatotrophin on growth and carcass quality in growing pigs: interactions with genotype, gender and slaughter weight. Journal of Animal Science, v.68, p.1193-1200, 1990. 
KAUFFMAN, R.G.; CASSENS WACHHOLZ, D.; HENDERSON, D.; LOCHNER, J.V. Shrinkage of PSE, normal and DFD hams during transit and processing. Journal of Animal Science, v.46, p.1236-1240, 1978.

KAUFFMAN, R.G.; CASSENS, R.G.; SCHERER, A.; MEEKER, D. L. Variations in pork quality. Des Moines: National Pork Producers Council Publication, 1992. 56p.

KIM, B.C.; KAUFFMAN, R.G.; NORMAN, J.M.; JOO, S.T. Measuring water holding capacity in pork musculature with a Tensiometer. Meat Science, v.39, p.363-374, 1995.

KLONT, R.E.; LAMBOOY, E.; VAN LOGTESTIJN, J.G. Effect of preslaughter anesthesia on muscle metabolism and meat quality of pigs of different halothane genotypes. Journal of Animal Science, v.71, p.1477, 1993.

KLONT, R.E.; LAMBOOY, E.; VAN LOGTESTIJN, J.G. Effect of dantrolene treatment on muscle metabolism and meat quality of pigs of anesthetized pigs of different halothane genotypes. Journal of Animal Science, v.72, p.2008, 1994.

KRICK, B.J.; RONEKER, K.R.; BOYD, R.D.; BEERMANN, P.J.; MEISINGER, D.J. Influence of genotype and sex on the response of growing pigs to recombinant porcine somatotrophin. Journal of Animal Science, v.70, p.3024-3034, 1992.

LAACK, R.L.J.M. van.; SMULDERS, F.J.M. The combined effects of skinning ang hot boning on meat quality. Fleischwirtsch, v.71, p.303-306, 1991. 
LAN, Y.H.; MCKEITH, F.K.; NOVAKOFSKI, J.; CARR, T.R. Carcass and muscle characteristics of Yorkshire, Meishan, Yorkshire $x$ Meishan, Meishan $x$ Yorkshire, Fengjing $x$ Yorkshire, and Minzhu $x$ Yorkshire pigs. Journal of Animal Science, v.71, p.3344-3349, 1993.

LARZUL, C.; LE ROY, P.; GUEBLEZ, R.; TALMANT, A.; GOGUE, J.; SELLIER, P.; MONIN, G. Effect of halothane genotype (NN, Nn e nn) on growth, carcass and meat quality traits of pigs slaughtered at $95 \mathrm{Kg}$ or $125 \mathrm{Kg}$ live weight. Journal of Animal Breeding and Genetics, v.114, p.309-320, 1997.

LATORRE, M.A.; LÁZARO, R.; GRACIA, M.I.; NIETO, M.; MATEOS, G.G. Effect of sex and terminal sire genotype on performance, carcass characteristics and meat quality of pigs slaughtered at $117 \mathrm{Kg}$ body weight. Meat Science, v.65, p.1369-1377, 2003.

LAURIDSEN, C.; NIELSEN, J.H.; HENCKEL, P.; SORENSEN, M.T. Antioxidative and oxidative status in muscles of pigs fed rapeseed oil, vitamin E and copper. Journal of Animal Science, v.77, p.105-115, 1999.

LAWRIE, R.A. Lawrie's meat science. Cambridge: Woodhead Publisher, 1988. $312 p$.

LEACH, L.M.; ELLIS, M.; SUTTON, D.S.; MCKEITH, F.K.; WILSON, E. R. The growth performance, carcass characteristics, and meat quality of halothane carrier and negative pigs. Journal of Animal Science, v.74, p.934-943, 1996. 
LEDWARD, D. A. Metamyoglobin formation in beef muscles as influenced by water content and anatomical location. Journal of Food Science, v.36, p.138-140, 1971.

LEFAUCHEUR, L.; MISSOHOU, A.; ECOLAN, P.; MONIN, G.; BONNEAU, M. Performance, plasma hormones, histochemical and biochemical muscle traits, and meat quality of pigs administered exogenous somatotrophin between 30 e $60 \mathrm{Kg}$ e $100 \mathrm{Kg}$ body weight. Journal of Animal Science, v.70, p.3401-3411, 1992.

LEHESKA, J.M.; WULF, D.M.; CLAPPER, J.A.; THALER, R.C.; MADDOCK, R.J. Effects of high protein/low carbohydrate swine diets during the final finishing phase on pork muscle quality. Journal of Animal Science, v.80, p.137-142, 2002.

LENGERKEN, G.; PFEIFFER, H.; HENNEBACH, H. Endogene und exogenem Einflusse auf die Fleischbeschaffenheit beim Schwein und Möglichkeiten der züchterischen Selection. Berlim: CAB International, 1980. $147 p$.

LE ROY, P.; MORENO, C.; ELSEN, J.M.; CARITEZ, J.C.; BILLON, Y.; LAGANT, H.; TALMANT, A.; VERNIN, P.; AMIGUES, Y.; SELLIER, P.; MONIN, G. Interactive effects of the HAL and RN major genes on carcass quality traits in pigs: preliminary results. In: ANNUAL MEETING OF THE EUROPEAN ASSOCIATIONS FOR ANIMAL PRODUCTION, 50., Zurich, 1999. Proceedings. Zurich: s. ed., 1999. p.38-52.

LE ROY, P.; NAVEAU, J.; ELSEN, J.M.; SELLIER, P. Evidence for a new major gene influencing meat quality in pigs. Genetic Research, v.55, p.33-40, 1990. 
LE ROY, P.; ELSEN, J.M.; CARITEZ, J.C.; TALMANT, A.; JUIN, H.; SELLIER, P.; MONIN, G. Comparison between the three porcine RN genotypes for grown, carcass composition and meat quality traits. Genetics Selection Evolution, v.32, p.165-186, 2000.

LOCKER, R.H.; HAGYARD, C.J. A cold shortening effect in beef muscles. Journal of the Science of Food and Agriculture, v.14, p.787-793, 1963.

LONERGAN, S.M.; HUFF-LONERGAN, E.; ROWE, L.J.; KUHLERS, D.L.; JUNGS, S.B. Selection for lean growth efficiency in Duroc pigs influences pork quality. Journal of Animal Science, v.79, p.2075-2085, 2001.

LOPEZ-BOTE, WARRIS, P.D. A note on the relationships between measures of water holding capacity in the muscle Longissimus dorsi and total drip loss from butchered pig carcasses during storage. Meat Science, v.23, p.227234, 1988.

LUNDSTRÖM, K.; ANDERSSON, A.; HANSSON, I. Effect of the RN gene on technological and sensory meat quality in crossbred pigs with Hampshire as terminal sire. Meat Science, v.42, p.145-153, 1996.

LUNDSTRÖM, K.; ESSEN-GUSTAVSSON, B.; RUNDGREN, M.; EDFORSLILJA, I.; MALMFORS, G. Effect of halothane genotype on muscle metabolism at slaughter and its relationship with meat quality: a within-litter comparision. Meat Science, v.25, p.251-264, 1989.

LUDVIGSEN, J. Undersogelser over den sakaldte "muskeldegeneration" hos svin. Beretning fra Forsogslaboratoriet, v.272, p.1-122, 1954. 
MADDOCK, R.J.; BIDNER, B.S.; CARR, S.N.; MCKEITH, F.K.; BERG, E.P.; SAVELL, J.W. Creatine monohydrate supplementation and the quality of fresh pork in normal and halothane carrier pigs. Journal of Animal Science, v.80, p.997-1004, 2002.

MALOVRH, S.; KOVAC, M. Ocena mesnatosti prasicev na Klavni liniji v Irtih 1996-1999 = Evaluation of lean meat content in slaughter pigs during 19961999. Sodobno Kmetijstvo, v.33, p.320-325, 2000.

MARTIN, A.H.; SATHER, A.P.; FREDEEN, H.T.; JOLLY, R.W. Alternative market weights for swine. II. Carcass composition and meat quality. Journal of Animal Science, v.50, p.699-705, 1980.

MARTIN, A.H.; FREDEEN, H.T.; WEISS, G.M.; FORTIN, A.; SIM, S. Yield of trimmed pork products in relation to weight and back fat thickness of the carcass. Canadian Journal of Animal Science, v.61, p.299, 1981.

MCCRAKEN, K.J.; BEATTIE, V.E.; WEATHERUP, R.N.; MCLIROY, S.G.; HENRY, R.W. Effects of diet energy density and protein (amino acid) content on intake, body composition and energy metabolism of boars and gilts fed at libitum from 22-46Kg. In: SYMPOSIUM ON ENERGY METABOLISM OF FARM ANIMALS, 14., Newcastle, 1997. Proceedings. Newcastle: STA, 1997. p.237-240.

MCGLOUGHGLIN, P.; ALLEN, P.; TARRANT, P.V.; JOSEPH, R.L. Growth and carcass quality of crossbred pigs sired by Duroc, Landrace and Large White boars. Livestock Production Science, v.18, p.275-288, 1988. 
MCPHEE, C.P.; DANIELS, L.J.; KRAMER, H.L.; MACBETH, G.M.; NOBLE, J.W. The effects of selection for lean growth and the halothane allele on growth performance and mortality of pigs in a tropical environment. Livestock Production Science, v.38, p.117-123, 1994.

MCPHEE, C.P.; TROUT, G.R. The effects of selection for lean growth and the halothane allele on carcass and meat quality of pigs transported long and short distances to slaughter. Livestock Production Science, v.42, p.55-62, 1995.

MEAT AND LIVESTOCK COMISSION. Stotfold pig development unit second trial results. Milton Keynes, 1992. 78p.

MILLER, M.F.; SHACKEIFORD, S.D.; HAYDEN, K.D.; REAGAN, J.O. Determination of the alteration in fatty acid profiles, sensory characteristics and carcass traits of swine fed elevated levels of monounsaturated fats in the diet. Journal of Animal Science, v.68, p.1624-1631, 1990.

MITTCHEL, G.; HEFFRON, J.J.A. Porcine stresse syndromes. Advances in Food Research, v.28, p.167-230, 1982.

MOELLER, S.J.; BAAS, T.J.; LEEDS, T.; EMNETT, R.S.; IRVIN, K.M. Effects of the Rendement Napole gene in Hampshire-sired pigs. In: WORLD CONGRESS ON GENETICS APPLIED TO LIVESTOCK PRODUCTION, 7., Montpellier, 2002. Proceedings. Montpellier, 2002. Session 3, p.1-4. 
MOELLER, S.J.; BAAS, T.J.; LEEDS, T.D.; EMNETT, R.S.; IRVIN, K.M. Rendement Napole gene effects and a comparison of glycolytic potential and DNA genotyping for classification of Rendement Napole status in Hampshiresired pigs. Journal of Animal Science, v.81, p.402-410, 2003.

MONIN, G.; SELLIER, P. Pork of low technological quality with a normal rate of muscle $\mathrm{pH}$ fall in the immediate post mortem period: the case of the Hampshire breed. Meat Science, v.13, p.49-63, 1985.

MORGAN, J.B.; SMITH, G.C.; CANNON, J.; MCKEITH, F.K.; HEAVNER, J. Pork chain quality audit: pork distribution channel audit report. Des Moines: National Pork Producers Council, 1994. 90p.

MOSS, M.; HOELDEN, J.M.; ONO, K.; CROSS, R.; SLOVER, H.; BERRY,B.; LANZA, E.; THOMPSON, R; WOLF, W.; VANDERSLICE, J.; JOHNSON, H.; STEWART, K. Nutrient composition of fresh retail pork. Journal of Food Science, v.48, p.1767-1771, 1983.

MURRAY, A.C.; JONES, S.D.M. The effect of mixing, feed restriction and genotype with respect to stress susceptibility on pork carcass and meat quality. Canadian Journal of Animal Science, v.74, p.587-594, 1994.

MURRAY, A.C.; JONES, S.D.M.; SATHER, P. The effect of preslaughter feed restriction and genotype for stress susceptibility on pork lean quality and composition. Canadian Journal of Animal Science, v.69, p.83, 1989. 
MURRAY, A.C.; JONES, S.D.M. The effect of mixing, fasting and genotype on carcass shrinkage and pork quality. In: INTERNATIONAL CONGRESS OF MEAT SCIENCE AND TECHNOLOGY, 1992. Proceedings. s.l.: s. ed., 1992. p.205-218.

NANNI, C.L.; LO FIEGO, D.P.; DALL'OLIO, S.; DAVOLI, R.; RUSSO, V. Combined effects of pre-slaughter treatments and lairage time on carcass and meat quality in pigs of different halothane genotype. Meat Science, v.61, p.41-47, 2002.

NAVEAU, J. The genetic determination of meat quality in pigs. Heritability of the technological yield of meat prepared by the "Napole" method. Journees de la Recherche Porcine en France, v.18, p.265-276, 1986.

NIEUWHOF, G.J.; KANIS, E.; VAN DER HEL, W.; VERSTEGEN, M.W.A.; HUIAMAN, J.; VAN DER WAL, P. Effect of recombinant porcine somatotropin on body composition and meat quality in growing pigs; Interactions with genotype, Sex and Slaughter Weight. Meat Science, v.30, p.265-278, 1991.

NIELSEN, N.J. The influence of pre-slaughter treatment on meat quality in pigs. Roskilde: Danish Meat Research Institute, 1977. 14p. (Slagterierns Forsknings institute Svin Kodvalitet MS, 561E)

NILZÉN, V.; BABOL, J.; DUTTA, P.C.; LUNDEHEIM, N.; ENFALT, A.C.; LUNDSTROM, K. Free range of pigs with access to pasture grazing: effect on fatty acid composition and lipid oxidation products. Meat Science, v.58, p.267-275, 2001. 
NOVAKOFSKI, J.; PARK, S.; BECHTEL, P.J.; McKEITH, F.K. Composition of cooked pork chops: effect of removing subcutaneous fat before cooking. Journal of Food Science, v.54, p.15-17, 1989.

NATIONAL PORK PRODUCERS COUNCIL (NPPC). Pork quality genetic evaluation summary. Des Moines, 1994. 1v.

OFFER, G.; KNIGHT, P. The structural basis of water holding in meat. Part 2: drip losses. In: LAWRIE, R. (Ed.). Development in meat science. London: Elsevier Applied Science, 1988. v.4, p.172-243.

OFFER, G. Drip losses in pork meat. Meat Science, v.30, p.157, 1991.

OKSBJERG, N.; HENCKEL, P.; ANDERSEN, S.; PEDERSEN, B. Genetic variation in muscle glycerol, glycogen and pigment in Danish pure breed pigs. In: INTERNATIONAL CONGRESS ON MEAT SCIENCE AND TECHNOLOGY, 47., Krakow, 2001. Proceedings. Krakow: Tibinty, 2001. p.30-31.

OKSBJERG, N.; PETERSEN, J.S.; SORENSEN, P.; HENCKEL, P.; VESTERgAARD, M.; ERTBJERG, P.; MOLLER, A.J.; BEJERHOLM, C.; STOIER, S. Long-term changes in performance and meat quality of Danish Landrace pigs: a study on a current compared with an unimproved genotype. Animal Science, v.71, p.81-92, 2000.

O'QUINN, P.R.; SMITH, J.W.; NELSSEN, J.L.; TOKACH, M.D.; GOODBAND, R.D.; SMITH, J.S. Effects of modified tall oil versus conjugated linoleic acid on finishing pig growth performance and carcass characteristics. Kansas State University Swine Day, v.2, n.1, p.162-166, 1998. 
O'QUINN, P.R.; ANDREWS, B.S.; GOODBAND, R.D.; UNRUH, J.A.; NELSSEN, J.L.; WOODWORTH, J.C.; TOKACH, M.D.; OWEN, K.Q. Effects of modified tall oil and creatine monohydrate on growth performance, carcass characteristics and meat quality of growing- finishing pigs. Journal of Animal Science, v.78, p.2376-2382, 2000.

PEARSON, A.M.; DUTSON, T.R. Electrical stimulation advances in meat research. Westport: AVI, 1985. 350p.

PETHICK, D.; WARNER, R.D.; D'SOUZA, D.N.; DUNSHEA, F.R. Nutritional manupulation of meat quality. In: CRANWELL, P.D. (Ed.). Manupulating pig production. Melbourne: SRF, 1997. p.91-123.

PHILLIPS, A.L.; FAUSTMAN, C.; LYNCH, P.B.; GOVONI, K.E.; HOAGLAND, T.A.; ZINN, S.A. Effect of dietary alpha-tocopherol supplementation on color and lipid stability in pork. Meat Science, v.58, p.289-293, 2001.

POMMIER, S.A.; HOUDE, A. Effect of the genptype for malignant hyperthermia as determined by a restriction endonuclease assay on the quality characteristics of commercial pork loins. Journal of Animal Science, v.71, p.420, 1993.

POMMIER, S.A.; HOUDE, F.A.; ROUSSEAU, F.; SAVOIE, Y. The effect of the malignant hyperthermia genotype as determined by a restriction endonuclease assay on characteristics of commercial crossbred pigs. Canadian Journal of Animal Science, v.72, p.973, 1992.

REITMEIER, C.A.; PRUSA, K.J. Cholesterol content and sensory analysis of ground pork as influenced by fat levels and heating. Journal of Food Science, v.52, p.916-918, 1987. 
RILEY, P.A.; ENSER, M.; NUTE, G.R.; WOOD, J.D. Effects of dietary linseed on nutritional value and other quality aspects of pig muscle and adipose tissue. Animal Science, v.71, p.483-500, 2000.

RING, C.; KORTMANN, R. Effect of electrical stunning on the quality of pig meat. Fleischwirstch, v.68, p.1421-1422, 1988.

ROPPA, L. Atualização sobre os níveis de colesterol, gordura e calorias das carnes suínas. Suinews, n.6, maio 1999.

ROPPA, L. A suinocultura no mundo. Anuário 2004. Porkworld. p.14-37, 2004.

ROSENVOLD, K.; ANDERSEN, H.J. Factors of significance for pork quality: a review. Meat Science, v.64, p.219-237, 2003.

ROSENVOLD, K.; LAERKE, H.N.; JENSEN, S.K.; KARLSSON, A.H.; LÜNDSTROM, K.; ANDERSEN, H.J. Strategic finishing feeding as a tool in the control of pork quality. Meat Science, v.59, p.397-406, 2001a.

ROSENVOLD, K.; LAERKE, H.N.; JENSEN, S.K.; KARLSSON, A.H.; LÜNDSTROM, K.; ANDERSEN, H.J. Manipulation of critical quality indicatiors and attributes in pork through vitamin E supplementation level, muscle glycogen reducing finishing feeding and preslaughter stress. Meat Science, v.62, p.485-496, 2002b. 
ROSENVOLD, K.; PETERSEN, J.S.; LAERKE, H.N.; JENSEN, S.K.; THERKILDSEN, M.; KARLSSON, A.H.; ANDERSEN, H.J. Muscle glycogen stores and meat quality as affected by strategic finishing feeding of slaughter pigs. Journal of Animal Science, v.79, p.382-391, 2001b.

RUNDGREN, M.; LUNDSTRÖM, K.; EDFORS, J.A. 1. A within-litter comparison of the three halotane genotypes. 2. Performance, carcass quality, organ development and long-term effects of transportation and amperozide. Livestock Production Science, v.26, p.231-243, 1990.

SANCHAI-JARURASITHA, X.; SCHEEDER, M.R.L.; KREUZER, M. Free range pigs: quality of the products from the meat label "Neuland". I. Differentiation from common products. Fleischwirtschaft, v.78, p.261-265, 1998.

SATHER, A.P.; JONES, S.D.M.; SCHAEFER, A.L.; COLYN, J.; ROBERTSON, W.M. Feedlot performance, carcass composition and meat quality of freerange reared pigs. Canadian Journal of Animal Science, v.77, p.225-232, 1997.

SAKATA, R.; DEGUCHI, T.; NAGATA, Y. Assessment of rapid method for determinig water holding capacity in meat. In: INTERNATIONAL CONGRESS OF MEAT SCIENCE AND TECHNOLOGY, Copenhagen, 1989. Proceedings. Copenhagen: Applied Denmark, 1989. p.181-181.

SARANTÓPOULOS, C.I.G.L.; PIZZINATTO, A. Fatores que afetam a cor das carnes. Coletânea do ITAL, v.20, n.1, p.1-12, 1990.

SAS INSTITUTE. SAS user's guide: statistics. Versão 5. Cary, 1985. 584p. 
SATHER, A.P.; JONES, S.D.M.; TONG, A.K.W.; MURRAY, A.C. Halothane genotype by weight interactions on pig meat quality. Canadian Journal of Animal Science, v.71, p.645-658, 1991.

SATHER, A.P.; JONES, S.D.M.; TONG, A.K.W.; MURRAY, A.C. Canadian Journal of Animal Science, v.71, p.633, 1991a.

SATHER, A.P.; JONES, S.D.M.; TONG, A.K.W.; MURRAY, A.C. Halothane genotype by weight interactions on pig meat quality. Canadian Journal of Animal Science, v.71, p.645, 1991b.

SATHER, A.P.; MURRAY, A.C.; ZAWADSKI, S.M.; JOHNSON, P. The effect of the halothane gene on pork production and meat quality of pigs reared under commercial conditions. Canadian Journal of Animal Science, v.71, p.959, 1991c.

SAYRE, R.N.; BRISKEY, E.J.; HOEKSTRA, W.G. Comparision of muscle characteristics and post mortem glycolysis in three breeds of swine. Journal of Animal Science, v.22, p.1012-1020, 1963.

SCHÄFER, A.; ROSENVOLD, K.; PURSLOW, P.P.; ANDERSEN, H.J.; HENCKEL, $\mathrm{P}$. Critical post mortem $\mathrm{pH}$ and temperature values in relation to drip loss in pork. In: INTERNATIONAL CONGRESS ON MEAT SCIENCE AND TECHNOLOGY, 47., Krakow, 2001. Proceedings. Krakow: Sputnik, 2001. p.206-207.

SCHÄFER, A.; ROSENVOLD, K.; PURSLOW, P.P.; ANDERSEN, H.J.; HENCKEL, P. Physiological and structural events post mortem of importance for drip loss in pork. Meat Science, v.61, p.355-366, 2002. 
SCHÜTTE, A.; WENZALOWICZ, M.; MICKWITZ, G. Animal transport and meat quality of pigs. Fleischwirtsch, v.74, p.126-132. 1994.

SELLIER, P. Crossbreeding and meat quality in pigs. In: TARRANT, P.V.; EIKELENBOOM, G.; MONIN, G. (Ed.). Evaluation and control of meat quality in pigs. Dordrecht: Martinus Nijhoff Publishers, 1987. p.329-358.

SELLIER, P.; MONIN, G. Genetics of pig meat quality: a review. Journal of Muscle Foods, v.5, p.187-219, 1994.

SELLIER, P. Genetics of meat and carcass traits. In: ROTHSCHILD, M.; Ruvinsky, A. (Ed.). The genetics of the pig. Wallingford: CAB International, 1998. p.436-510.

SENCIC, D.; ANTUNOVIC, Z.; SPERANDA, M. Meatiness and meat quality in pigs crossed with Pietrain. Stocarstvo, v.56, p.191-196, 2002.

SHEARD, P.R.; ENSER, M.; WOOD, J.D.; NUTE, G.R.; GILL, B.P.; RICHARDSON, R.I. Shelf life and quality of pork and pork products with raised n-3 PUFA. Meat Science, v.55, p.13-221, 2000.

SHULER, R.O.; PATE, T.D.; MANDIGO, R.W.; LUCAS, L.E. Influence of confinement, floor structure and slaughter weight on pork carcass characteristics. Journal of Animal Science, v.31, p.31-35, 1970.

SILVEIRA, E.T.F. Técnicas de abate e seus efeitos na qualidade da carne suína. Campinas, 1997. 247p. Tese (Doutorado) - Faculdade de Engenharia de Alimentos, Universidade Estadual de Campinas. 
SIMPSON, S.P.; WEBB, A.J. Growth and carcass performance of British Landrace pigs heterozygous at the halothane locus. Animal Production, v.49, p.503, 1989.

SIMPSON, S.P., WEBB, A.J.; DICK, S. Evaluation of Large White and Duroc boars as terminal sires under two different feeding regimes. Animal Production, v.45, p.111-116, 1987.

SOSNICKI, A.; WILSON, E.R.; SHEISS, E.B.; VRIES, A.D. Is there as cost effective way to produce high qulity pork? In: RECIPROCAL MEAT CONFERENCE, Califórnia, 1998. Proceedings. Califórnia: CAB International, 1998. p.11-28.

STAHL, C.A.; ALLEE, G.L.; BERG, E.P. Creatine monohydrate supplemented in swine finishing diets and fresh pork quality: II. Commercial applications. Journal of Animal Science, v.79, p.3081-3086, 2001.

STAHLY, T.S. Amino acids in growing, finishing, and breeding swine. In: NATIONAL FEED INGREDIENT ASSOCIATION NUTRITION INSTITUTE, Chicago, 1991. Proceedings. Chicago: IL, 1991. p.48-60.

STOIER, S.; AASLYNG, M.D.; OLSEN, E.V.; HENCKEL, P. The effect of stress during lairage and stunning on muscle metabolism and drip loss in Danish pork. Meat Science, v.59, p.127-131, 2001.

SUNDRUM, A.; DÜTFERING, L.; HENNING, M.; HOPPENBROCK, K.H. Effects of on-farm diets for organic pig production on performance and carcass quality. Journal of Animal Science, v.78, p.1199-1205, 2000. 
SUTTON, D.S.; ELLIS, M.; LAN, Y.; MCKEITH, F.K.; WILSON, E.R. Influence of slaughter weight and stress gene genotype on the water holding capacity and protein gel characteristics of three porcine muscles. Meat Science, v.46, p.173-180, 1997.

SUZUKI, K.; SHIBATA, T.; KADOWAKI, H.; ABE, H.; TOYOSHIMA, T. Meat quality comparison of Berkshire, Duroc and crossbred pigs sired by Berkshire and Duroc. Meat Science, v.64, p.35-42, 2003.

TAM, L. G.; BERG, E.P.; GERRARD, D.E.; SHEISS, E.B.; TAN, F. J.; OKOS, M. R.; FORREST, J.C. Effect of Halothane genotype on porcine meat quality and myoglobin autoxidation. Meat Science, v.47, p.41-53, 1997.

TAYLOR, A.A.; DANT, S.J. Influence of carcass cooling rate on drip loss in pigment. Journal of Food Technology, v.6, p.131-139, 1971.

TAYLOR, A.A.; TANTIKOV, M.Z. Effect of different electrical stimulation and chilling treatments on pork quality. Meat Science, v.31, p.381-395, 1992.

TAYLOR, A.A.; MARTOCCIA, L. The effect of low voltage and high voltage electrical stimulation on pork quality. Meat Science, v.39, p.319 - 326, 1995.

THIEL-COOPER, R.L.; SPARKS, J.C.; WEIGAND, B.R.; PARRISH, F.C.J.; EWAN, R.C. Conjugated linoleic acid improves performance and body composition in swine. Journal of Animal Science, v.76, p.61, 1998. Supplement 1.

THIEL-COOPER, R.L.; SPARKS, J.C.; WEIGAND, B.R.; PARRISH, F.C.J.; EWAN, R.C. Conjugated linoleic acid changes swine performance and carcass composition. Journal of Animal Science, v.79, p.1821-1828, 2001. 
TOR, M.; ESTANY, J.; VILLALBA, D.; CUBILO, D.; TIBAU, J.; SOLER, J.; SANCHEZ, A.; NOGUERA, J.L. A within-breed comparison of RYR1 pig genotypes for performance, feeding behaviour, and carcass, meat and fat quality traits. Journal of Animal Breeding and Genetics, v.118, p.417-427, 2001.

TOURAILLE, C.; MONIN, G.; LEGAULT, C. Eating quality of meat from European x Chinese crossbred pigs. Meat Science, v.25, p.177-186, 1989.

TU, C.; POWRIE, W.D.; FENEMA, O. Free and esterified cholesterol content of animal muscles and meat products. Journal of Food Science, v.32, p.3034, 1967.

UNRUH, J.A.; FRIESEN, K.G.; STUEWE, S.R.; DUNN, B.L.; NELSSEN, J.L.; GOODBAND, R.D.; TOKACH, M.D. The influence of genotype, sex, and dietary lisyne on pork subprimal cut yields and carcass quality of pigs fed to either 104 or 127 kilograms. Journal of Animal Science, v.74, p.1274-1283, 1996.

VAN-OECKEL, M.J.; WARNANTS, N.; BOUCQUE, C.H.V.; DELPUTTE, P.; DEPUYDT, J. The preference of the consumer for pork from homozygous or heterozygous halothane negative animals. Meat-Science, v.58, n.3, p.247251, 2001.

VAN DER WAL, P.G.; NIJEBOER, H.; MERKUS, G.S.M. The measurement of light scattering properties at 45 min post mortem for prediction of pork quality. In: TARRANT, P.V.; EIKELENBOOM, G.; MONIN, G. Evaluation and control of meat quality in pigs. Dordrecht: Martinus Nijhoff Publishers, 1987. p.201-247. 
VAN DER WAL, P.G.; BOLINK, A.H.; MERKUS, G.S.M. Differences in quality characteristics of normal, PSE and DFD pork. Meat Science, v.24, p.79-84, 1988.

VAN DER WAL, P.G.; ENGEL, B.; HULSEGGE, B. Causes for variation in pork quality. Meat Science, v.46, p.319-327, 1997.

VAN DER WAL, P.G.; ENGEL, B.; REIMERT, H.G.M. The effect of stress, applied immediately before stunning, on pork quality. Meat Science, v.53, p.101-106, 1999.

VAN LAACK, R.L.J.M.; KAUFFMAN, R.G.; SYBESMA, W.; SMULDERS, F.J.M.; FIKELENBOOM, G.; PINHEIRO, J.C. Journal of Muscle Foods, v.7, p.149, 1996.

WAGNER, J.R.; SCHINCKEL, A.P.; CHEN, W.; FORREST, J.C.; COE, B.L. Analyses of body composition changes of swine during growth and development. Journal of Animal Science, v.77, p.1442-1466, 1999.

WARNANTS, N.; VAN OECKEL, M.J.; BOUQUÉ, C.V. Incorporation of dietary polyunsaturated fatty acids in pork tissues and its implications for the quality of the end products. Meat Science, v.44, p.125-144, 1996.

WARNANTS, N.; van OECKEL, M.J.; BOUCQUÉ, C.V. Effect of incorporation of dietary polyunsaturated fatty acids in pork backfat on the quality of salami. Meat Science, v.49, p.435-445, 1998. 
WARNANTS, N.; OECKEL, M.J.; BOUCQUÉ, C.V. Incorporation of dietary polyunsaturated fatty acids in pork fatty tissues. Journal of Animal Science, v.77, p.2478-2490, 1999.

WARNER, R.D.; KAUFFMAN, R.G.; GREASER, M.L. Muscle protein changes post mortem in relation to pork quality traits. Meat Science, v.45, p.339-352, 1996.

WARNER, R.D.; KAUFFMAN, R.G.; GREASER, M.L. Muscle protein changes post mortem in relation to pork quality traits. Meat Science, v.45, p.339-352, 1997.

WARNER, R.D.; KAUFFMANN, R.G.; RUSSEL, R.I. Meat Science, v.33, p.359, 1993.

WARRISS, P.D. The relationship between $\mathrm{pH} 45$ and drip in pig muscle. Journal of Food Technology, v.17, p.573-578, 1982.

WARRISS, P.D.; BROWN, S.N. The physiological responses to fighting in pigs and the consequences for meat quality. Journal of the Science of Food and Agriculture, v.36, p.87-92, 1985.

WARRISS, P.D. Liver glycogen in slaughter pigs and estimated time of fasting before slaughter. British Veterinary Journal, v.143, p.354-360, 1987.

WARRISS, P.D.; KESTIN, S.C.; BROWN, S.N.; KNOWLES, T.G.; WILKINS, L.J.; EDWARDS, J.E.; AUSTIN, S.D.; NICOL, C.J. The depletion of glycogen stores and indices of dehydration in transported broilers. British Veterinary Journal, v.149, p.391-398, 1993. 
WARRISS, P.D. Ante-mortem handling of pigs. In: COLE, D.J.A.; WISEMAN, J.; VARLEY, M.A. (Ed.). Principles of pig science. Loughborough: Nottingham Universiti Press, 1994. p.425-432.

WARRISS, P.D. The welfare of slaughter pigs during transport. Animal Welfare, v.7, p.365-381, 1998.

WARRISS, P.D.; BROWN, S.N.; EDWARDS, J.E.; KNOWLES, T.G. Effect of lairage time on levels of stress and meat quality in pigs. Animal Science, v.66, p.255-261, 1988b.

WARRISS, P.D.; BROWN, S.N.; BARTON, G.P.; SANTOS, C.; NANNI, C.L.; LAMBOOIJ, E.; GEERS, R. An analysis of data relating to pig carcass quality and indices of stress collected in the European Union. Meat Science, v.49, p.137-144, 1998a.

WEBEL, D.M. Effect of betaine supplementation on growth performance, carcass characteristics, and nitrogen retention of finishing pigs. Illinois, 1994. 180p. Thesis (M.S.) - University of Illinois.

WEEB, A.J.; GRUNDY, B.; KITCHIN, P. Within-litter effect of the HAL-1843 heterozygote on lean growth in pigs. In: WORLD CONGRESS GENETIC APPLIED LIVESTOCK PRODUCTION, 5., Guelph, 1994. Proceedings. Guelph: s. ed., 1994. p.421-437.

WEBB, A.J.; CARDEN, A.E.; SMITH, C.; IMLAH, P. Porcine stress syndrome in pig breeding. In: WORLD CONGRESS OF GENETICS APPLIED TO LIVESTOCK PRODUCTION, 2., Madrid, 1982. Proceedings. Madrid: CAB international, 1982. p.588-623. 
WIEGAND, B.R.; SWAN, J.E.; PARRISH, F.C.J.; BASS, T.J. Influence of dietary conjugated linoleic acid on meat quality and sensory traits of stress-genotype pigs. Journal of Animal Science, v.78, p.157, 2000. Supplement 1.

WIEGAND, B.R.; PARRISH, F.C.J.; SWAN, J.E.; LARSEN, S.T.; BAAS, T.J. Conjugated linoleic acid improves feed efficiency, decreases subcutaneous fat, and improves certain aspects of meat quality in stress-genotype pigs. Journal of Animal Science, v.79, p.2187-2195, 2001.

WIRTH, F. Technologie der Verarbeitung von Fleisc mit abweichender Beschaffenheit. Fleischwirtschaft, v.65, p.998-1011, 1986.

WITTMANN, W.; ECOLAN, P.; LEVASSEUR, P.; FERNANDEZ, X. Fastinginduced glycogen depletion in different fibre types of red and white pig muscles: relationship with ultimate $\mathrm{pH}$. Journal of the Science of Food and Agriculture, v.66, p.257-266, 1994.

WOOD, J.D.; WARRISS, P.D. Environmental influences on meat quality. In: Annual Meeting of EAAP, 41., Toulouse, 1990. Proceedings. Toulouse: Francis Publishers, 1990. p.304-322.

WOOD, J.D.; ENSER, M. Factors influencing fatty acids in meat and the role of antioxidants in improving meat quality. British Journal of Nutrition, v.78, p.49-60, 1997. 